\title{
BIJDRAGE TOT DE KENNIS DER ROTTINEESCHE TONGVALLEN.
}

DOOR J. C. G. JONKER.

Reeds vroeger is er in deze Bijdragen op gewezen, dat de taal, gesproken op het eiland Rotti, in meerdere dialecten is gesplitst. Men zie de mededeelingen van D. P. Manafe, (uitgesproken Manafè, met den klemtoon op de laatste lettergreep), onder den titel "Akan bahasa Rotti», opgenomen in Bijdr. XXXVIII (pag. 636, volg.), en de opmerkingen van Kern bij de Nederlandsch-Rottineesche Samenspraken, (Bijdr. XLII, pag. 71 vlg.). In mijn Rottineesch Wdb., volgens het dialect van Termanu of Pada, zijn ook opgenomen de afwijkende woordvormen, voor zooverre zij niet uit regelmatige, aldaar opgegeven klankveranderingen voortvloeien, benevens de mij bekende bijzondere woorden, eigen aan de overige tongvallen, Tevens heb ik aldaar in het Voorbericht medegedeeld, dat mij meerdere tongvallen slechts zeer onvolledig bekend zijn, alleen uit enkele, daarin opgestelde kleinere verhalen en vertalingen, benevens de terzelfder plaatse genoemde lijsten; mijne kennis bepaalt zich dus tot enkele feiten, welke ook uit het geschreven woord kunnen blijken, (al heb ik, althans de meeste der van het Termanusch afwijkende dialecten, wel eene enkele maal hooren spreken), betreffende klankverschijnselen, grammaticale bijzonderheden en afwijkingen in het woordgebruik. Gelijk de laatste in het Wdb. zijn opgenomen, worden al wat mij omtrent de bijzondere klankverschijnselen en de, met enkele uitzonderingen, niet groote of talrijke verschillen van grammaticalen aard, welke de overige tongvallen tegenover het Termanusch vertoonen, in de thans ter perse zijnde Sprk. besproken. Bij den tegenwoordigen stand onzer kennis blijft dus nog alleen over eene samenvatting der uitkomsten, ten einde den onderlingen graad van verwantschap dezer dialecten te bepalen, hetgeen hier in het kort zal beproefd worden. De eigenlijke bedoeling dezer bijdrage tot de kennis

Dl. 68 . 
der Rottineesche tongvallen is de publiceering der bovengenoemde verhalen en vertalingen, als noodzakelijke complețeering van het elders geleverde, ten einde zoo den weg te effenen voor eene latere meer nauwkeurige en meer grondige bestudeering dezer dialecten.

In zijn bovengenoemd stuk "Akan bahasa Rotti» onderscheidt Manafè 9 dialecten: 1. dat van Ringgou of Renggou, gesproken in de landschappen Ringgou (eigenlijk volgens den eigen tongval Raikou, elders Rainggou of Lainggou genaamd), Òepao en Landu; 2. dat van Bilba gesproken in de landschappen Bilba (eig. Belubá), Diu en Lelenuk; 3. dat van Korbaffo (eig. Kolobafo of Korobafo), gesproken in het gelijknamige landschap; 4. dat van Tĕrmanu of Tărmanu, gesproken in het eigenlijke Terrmanu (Pada), voorts in Keka en Talae; 5. dat van Bokai, gesproken in het landschap van denzelfden naam; 6 . dat van Baä, gesproken in Baä en Lòle; 7. dat van Dengka, gesproken in Dengka (Dengga, Denga) en Lelain; 8. dat van Ti gesproken in het gelijknamige landschap; 9. dat van Òenale, gesproken in Òenale en Dela.

De eerste 5 worden gesproken in dat deel van het eiland, wat de Rottineezen Oost-Rotti noemen, de laatste vier in WestRotti. Eene zelfde onderscheiding wordt door meerderen gemaakt, alleen wordt gewoonlijk Lòle als een van Baä verschillenden tongval opgegeven. Door sommigen worden evenwel veel meer dialecten opgesomd, ook kan de indeeling wel verschillen, en wordt Bokai wel eens tot Bilba gerekend.

Het is natuurlijk in het algemeen moeielijk of niet te zeggen, hoe groot de afwijkingen moeten zijn, welke de in een gedeelte van een land gesproken taal tegenover die in eene andere streek vertoont, dat zij met recht als een afzonderlijk dialect kan beschouwd worden. Neemt men elk verschil in woordgebruik en wijze van spreken, wat betreft de toonhoogte of het tempo ${ }^{1}$, enz. in aanmerking, dan zal men stellig in het Rottineesch nog veel meer tongvallen kunnen onderscheiden. Bestempelt men met den naam dialect alleen die afdeelingen, welke zich onderscheiden door grootere verschillen, die blijken uit de klankverschijnselen of uit de grammatica, hetzij te zamen of afzonderlijk, dan kan gezegd worden, dat de 9 door Manafè

1 Vgl. Manafè 1.I.: Lelenuk punja lagu sarupa dĕngan Bilba dan Diu, akan tĕtapi Lelenuk bĕrtjakap lĕbih ladju dari Diu dan Bilba. 
opgesomde, wel-aan de vereischten voldoen, al zijn de verschillen nu niet overal even groot, terwijl daarentegen, om een voorbeeld te noemen, de taal, gelijk zij in Keka gesproken wordt, welke door sommigen als een afzonderlijk dialect wordt beschouwd, niet op dezelfde wijze als bijv. die van Ringgou, of zelfs die van Korbaffo tegenover het Termanusch, gesteld kan worden, maar alleen als een onderdialect van het laatste te beschouwen is; eene fijnere onderscheiding dus, welke voorloopig verwaarloosd kan worden. Evenwel niet altijd, waar Manafè de taal van meerdere landschappen tot een zelfde dialect brengt, is daarin alles zoo geheel en al hetzelfde. Zelf zegt hij, dat de uitspraak van sommige woorden in Òepao, Ringgou en Landu verschillend is, en geeft als voorbeeld het woord voor "paard" (Term. ndala), dat in Òepao: rara, in Ringgou: dara, in Landu: ndara luidt.

Neemt men nu in aanmerking, dat elke Ringgousche nd in een woord in het Òepaosch regelmatig tot $r$ wordt, (bijv. Òepao bara = Ringgou $b$ anda $=$ Term. ban a dier), dan zou men kunnen vragen, waarom dé taal van Òepao niet evengoed als bijv. die van Bokai als een afzonderlijk hoofddialect wordt beschouwd, (de juiste verhouding tusschen het Landusch en het eigenlijke Ringgousch is mij niet bekend; uit hetgeen Manafè opgeeft, schijnt te blijken, dat het Landusch vóór aan het woord, in overeenstemming met het Term., eene nd behoudt, terwijl die in het Ringgousch tot $r$ wordt, als: Landu, Term. ndia $=$ Ringgou ria, hij). De oorzaak, waarom dit niet zoo is, is gemakkelijk na te gaan. De taal, gelijk zij in de drie genoemde landschappen gesproken wordt, onderscheidt zich opvallend van die van het overige gedeelte van Rotti door de $k$, welke in de plaats gekomen is van eene $\mathrm{ngg}^{1}$ (soms verloopen tot $\mathrm{ng}$ ) elders, wat haar, voor iemand uit eene andere streek, een vreemd voorkomen geeft. Belangstelling voor zulke zaken, als de verdeeling der taal in tongvallen, komt tot dusverre wel nagenoeg alleen voor bij sommigen in Termanu en Baä, (ook Manafè is uit Baä afkomstig); voor hen moesten de overige afwijkingen wel nauwelijks in aanmerking komen.

Ware de onderscheiding uitgegaan van iemand afkomstig uit

1 Nam. de $\mathrm{ngg}$, welke eens algemeen Rottineesch moet geweest zijn; over de eigenlijke waarde wordt in de Spk. gesproken. Ditzelfde geldt wanneer er beneden sprake is van de $\mathrm{nd}, \mathrm{mb}, \mathrm{mp}$ of $p$. 
Ringgou, bijv., dan zouden denkelijk het Ringgousch, Òepaosch en Landusch als hoofd-dialecten vermeld en mogelijk omgekeerd eenige andere uit de opsomming vervallen zijn.

Reeds is gezegd, dat de meesten de taal van Lòle als een afzonderlijk dialect beschouwen; dit geschiedt zeker te recht. Waarom Manafè dezen tongval eenvoudig bij Baä brengt, is mij niet duidelijk; men zou haast denken alleen om het taalgebied van Baä, dat in vergelijking met dat van Termanu gering van omvang is, wat meer uitgebreidheid te geven. Mij is het betrekkelijk laat eerst duidelijk geworden, dat de taal van Lòle werkelijk als een afzonderlijk dialect, niet als een sub-dialect beschouwd moet worden, zoodat ik niet in het bezit ben van stukken in dat dialect gesteld; over de voornaamste kenmerken zie voorts hieronder.

Evenwel, al moge het Òepaosch een afzonderlijk dialect genoemd worden, zoo staat het toch zeer dicht bij het Ringgousch; eveneens staat de tongval van Lòle zeer na aan dien van Baä; en al is het mogelijk, dat ook de taal van een of ander der overige landschappen, welke door Manafè tot eene der boven-opgesomde dialecten wordt gerekend, bij nadere bekendheid zou blijken soortgelijke afwijkingen te vertoonen, zoo is het toch met groote waarschijnlijkheid te vooronderstellen, dat ook zij dan zal blijken zeer nauw verwant te zijn met het dialect, waartoe zij in de door Manafè opgestelde verdeeling gebracht is, zoodat deze voor eene bespreking van hun onderlingen graad van verwantschap geheel voldoende is.

Reeds bij eene oppervlakkige beschouwing der Rottineesche dialecten valt het op, dat een gedeelte daarvan den $r$-klank mist, en daarvoor steeds eene $l$ bezigt, terwijl in een ander deel de $r$ naast de $l$ is behouden; men kan de eerste dus onderscheiden met den naam van $l$-dialecten, terwijl men dan de andere bij verkorting met de benaming van $r$-dialecten kan bestempelen, al is deze naam ook eigenlijk onjuist, (werkelijke $r$-dialecten, dus zulke, welke alleen eene $r$, geen $l$, kennen, komen niet bij het Rottineesch, wel bij het Timoreesch voor).

Het ligt voor de hand, dat men begonnen is de dialecten te onderscheiden naar het al of niet voorkomen van de $r$, vgl. de opmerkingen van Kern bij de bovengenoemde Ned. Rott. Smspr. Bij eene nadere bekendheid met de verschillende dialecten, blijkt evenwel al spoedig, dat deze onderscheiding met hun graad van verwantschap niets te maken heeft. Het duidelijkste 
komt dit uit bij de tongvallen van Dengka en Òenale. Deze beide vertoonen de grootste verschillen met wat men de (uit de dialecten geabstraheerde) algemeene taal mag noemen en komen in die afwijkingen nagenoeg altijd overeen; zij zijn dus nauw verwant; evenwel behoort het eerste tot de $l$-, het tweede tot de $r$-dialecten. Ook de overige $r$-dialecten, namelijk dat van $\mathrm{Ti}$ en dat van Ringgou, (met het Landusch en Òepaosch) staan duidelijk verder van elkander dan van sommige $l$-dialecten, en evengoed doet zich het omgekeerde geval voor. Neemt men in aanmerking, dat de $l$-dialecten in geographisch opzicht een aaneengesloten geheel vormen, terwijl de $r$-dialecten geïsoleerd voorkomen aan het Westelijk (en Zuid-Westelijk) en Oostelijk uiteinde van Rotti, (benevens op Landu), dan makt dit waarschijnlijk, dat het verlies van de oorspronkelijke $r$ op het grootste deel van het eiland ontstaan is door inwerking der dialecten op elkander, al zal nu wel niet, of moeielijk na te gaan zijn, van waar deze neiging uitgegaan is. De aanleg was natuurlijk overal aanwezig, blijkens dezelfde verwarring van $l$ en $r$ in het verwante Timoreesch.

Gelijk gezegd is, vertoonen de dialecten van Dengka en Òenale de grootste afwijkingen, en wel in verschillende opzichten. In de eerste plaats komen er afwijkingen voor van grammaticalen aard. Terwijl bijv. overigens op geheel Rotti een werkwoord op de volgende wijze vervoegd wordt, als: a fada of kafada, (ik zeg), mafada, (gij zegt), nafada, (hij zegt), t a fada, (wij, inclus., zeggen), maf a da, (wij, exclus., zeggen), mafada, (gijl. zegt), lafada of rafada, (zij zeggen), luidt de vervoeging in genoemde dialecten: ufade, mufade, nafade, tafade, mifade, mifade, D. lafade, Òen. rafade. Duidelijker nog komt het verschil uit, als het verbum van een prefix voorzien is, door zekere vocaal-harmonie, dewijl de vocaal van het prefix de kleur van het voorafgaand pronomen aanneemt, dus naast amanasa of kamanasa, mamanasa, namanas, tamanasa, mamanasa, mamanasa, lamanasa of ramanasa (ik ben toornig, enz.), elders: umunasa, mumunasa, namanasa, tamanasa, miminasa, miminasa, lamanasa of ramanasa. Hoewel natuurlijk de vormen, (zonder prefix), in de overige dialecten, oorspronkelijk identiek moeten geweest zijn met die in Dengka en Òenale, staan deze tongvallen hierin toch op een ander standpunt van ontwikkeling, en wel 
op dat, waarop zich ook het Timoreesch bevindt. Als partikel tot aanduiding van den verleden tijd wordt overal op Rotti, (behalve in Ti), s ò gebezigd, doch in D. en Oen. luidt dit en a in overeenstemming met Timoreesch en. Tot vorming van verbale substantieven dient in D. en Òen. ook nog de toevoeging van eene $t$, in overeenstemming met het Timoreesch, terwijl elders op Rotti, (de $s$ buiten rekening gelaten), alleen de $k$ of de daaruit ontstane ingeslikte medeklinker daartoe dient, (bijv. $\mathrm{n}$ a nát, voedsel, elders: nanä̈k, n a naä, nanạ́, van naä, $\mathrm{n} \hat{\mathrm{a}}$, hij eet). Het volledige voornw. van den $3^{\text {den }}$ pers. enkelv. luidt in D. en Òen. en i, (Tim. in), en de niet nadrukkelijke objects-vorm daarvan $e$, (Tim. idem), terwijl zij overal elders op Rotti respectievelijk ndia, (lia, ria) en $-n$ (na) luiden. Ook bij den vorm van andere pers. voornw. komt overeenstemming met het Timoreesch voor, bijv. hita, Tim. hit, overal elders ita, wij (inclus.); hai, Tim. idem, op Oost-Rotti steeds a mi, wij (exclus.); hò, Tim. idem, elders ò of kò, gij; hei, Tim. $\mathrm{hi}$, op Oost-Rotti steeds emi of kemi, gijl. Terwijl overal elders op Rotti als partikel voor de ontkenning ta gebezigd wordt, luidt dit in Dengka $\mathrm{ngga}=$ Timoreesch $\mathrm{ka}$, (Òenale heeft hier, in afwijking nda). En zoo zouden er, op wat men tot grammaticaal gebied kan rekenen, nog meerdere verschillen vermeld kunnen worden.

Daargelaten de klanken, welke ook in de overige dialecten kunnen verschillen, zijn aan D. en Òen. bijzonder eigen de $l$ (in Òen. $r$ ), waar de overige tongvallen $d$ vertoonen in overeenstemming met het Maleisch, tegenover eene Javaansche $r$, als in lua, rua, elders dua, twee; ale, are, elders hade, rijst, padi; enz. Vgl. Timoreesch nua, ane(l), enz. met de Timor. $n$ uit $l$. Ook in meerdere andere gevallen komt de vorm van een woord in D. en Òen. meer overeen met den Timoreeschen, bijv. fulụ, Tim. funuf, haar, vederen; hau, (Tim. idem), boom, hout; ume, Tim. ume(l), huis, terwijl die woorden elders op Rotti buluk of bulụ; ai of kai; uma, luiden.

Ook zijn D. en Òen. het rijkst aan eigen woorden, elders niet of althans alleen in een klein gedeelte van het eiland gangbaar, welke meermalen (doch volstrekt niet altijd) ook in het Timoreesch voorkomen. ${ }^{1}$

1 Op te merken is, dat er ook een aantal met het Sawuneesch overeenkomende woorden voorkomen, (ofschoon ik uit dit feit nog volstrekt geen 
Doch niettegenstaande deze afwijkingen is het type der taal, ook in D. en Òen., Rottineesch, en volstrekt niet Timoreesch; ook het grootste deel van den woordenschat is de algemeen Rottineesche.

Volgens de Rottineesche overlevering zouden zich op twee achtereenvolgende keeren, volksplanters op het eiland, dat voorheen onbewoond was, gevestigd hebben. De eersten zouden van Ceram over Timor op Rotti gekomen zijn en zich in het Westelijke deel van het eiland neergezet hebben, terwijl later het Oostelijke deel zou bevolkt zijn door nieuwe volksplanters, eveneens van of over Timor gekomen. Gelijk boven reeds gezegd is, onderscheiden de Rottineezen nog altijd een Westelijk en een Oostelijk deel van het eiland. De bewoners van het eerste worden genoemd: Hendak (of Henak, enz.) - ana-n,

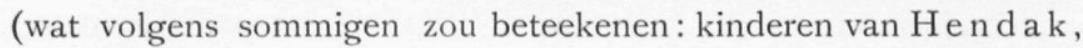
een der eerste volksplanters, terwijl zij volgens anderen dien naam zouden dragen, omdat zij een tijd lang hadden moeten leven van den pandanus: hendak, henak, enz.); die van het andere deel Lamak-ana-n, (dewijl zij źich een tijdlang met sprinkhanen, la mak, zouden hebben moeten voeden).

Men kan wel aannemen, dat er een kern van waarheid in deze overlevering schuilt, ook daarin, dat er oorspronkelijk verschil bestond tusschen de bewoners van West- en Oost-Rotti, wat, gelijk bij een bepaalden graad van beschaving reeds vanzelf spreekt, gepaard ging met verschil van taal. Naar alle waarschijnlijkheid is de bevolking van West-Rotti onder invloed gekomen van die van het Oostelijke deel, ook wat betreft hare taal, welke in elk geval, gelijk nu nog uit de afwijkingen te zien is, ofschoon meer naar het Timoreesch overhellende, toch zeer na verwant was aan die van de Oost-Rottineezen, gelijk ook overigens het Rottineesch en Timoreesch zeer dicht bij elkander staan. In een deel der landschappen heeft dientengevolge ook de taal geheel een Oost-Rottineesch karakter gekregen,

conclusie kan trekken), waaronder opmerkelijke, als bijv. monae, kapai, welke beide "groot" beteekenen, stellig het Saw. mone-a e, (eigenlijk: groot= volwassen-mannelijk), en kepai. Ook het Ringgousch heeft sommige woorden (doch van anderen aard) met het Sawuneesch gemeen, bijv. $\mathrm{n}$ af $\mathrm{a}=$ Saw. nawa, golf, (elders op Rotti li, ri, en D. lè, en On. rè.) Bekend is, dat op het eilandje Dao (of $\mathrm{Ndao}$ ) nog een soort, onder invloed van het Rottineesch staand Sawuneesch gesproken wordt. 
ofschoon er enkele bijzonderheden voorkomen, welke nog in verband staan met de taal van Dengka en Òenale, (vgl. beneden). En waar er aan den uitersten Westkant nog het meest van overgebleven is, is de invloed toch groot genoeg geweest, dat de eertijds verschillende taal, thans tot dialecten van de algemeene taal geworden zijn, en voor zooverre ik naar mijne gegevens oordeelen kan, schijnen meerdere van de meer gewichtige verschillen steeds meer uit te slijten. Evenwel moet de uitspraak van Manafè, dat elke Rottinees, van welk deel van het eiland ook afkomstig, de taal van iemand uit eenig ander gedeelte kan verstaan, wat de tongvallen van Dengka en Òenale betreft, toch altijd met eenige reserve aangenomen worden; trouwens ook in andere gevallen moet men de uitdrukking "dapat mengarti» niet al te letterlijk opvatten.

Vergelijkt men het dialect van Baä met dat van Termanu, wat nu eenmaal als het hoofddialect wordt beschouwd, ofschoon, gelijk doorgaans het geval is, de redenen daarvoor niet van taalkundigen aard zijn, dan blijkt 't, dat het daarvan al zeer weinig afwijkt. Afgezien van het voorkomen van enkele gewestelijke woorden, bestaat het verschil voornamelijk daarin, dat een oudere $\mathrm{ngg}$ in het woord, welke in het Term. tot $\mathrm{ng}$ moet worden, behouden is, en dat, waar in het Term. eene $p$ voorkomt in overeenstemming met alle Oostelijke tongvallen, het Baäsch daarvoor meermalen eene $\mathrm{mp}$ vertoont, (in overeenstemming met de $\mathrm{mb}$ in Dengka en Òenale). Eigenlijke verschillen van grammaticalen aard zijn mij niet bekend; alleen wijst de vorm der voornw. a i, (wij, excl.) en ei (gijl.), tegenover a mi en emi, kemi in de Oostelijke dialecten, door het verlies van de $m$ meer op overeenkomst met D., Òen. hai, hei. Overigens weet ik geen andere punten van aanraking met genoemde dialecten, behalve, het niet zooveel beteekenende feit, dat meerdere gewestelijke woorden, welke overigens in OostRotti niet gangbaar zijn, hier nog in overeenstemming met D. en Òen. voorkomen.

Het dialect van $\mathrm{Ti}$ vertoont nog andere punten van overeenkomst. Vooral van belang is, behalve de vorm der voornw. a i, ei als in Baä, het gebruik van ena, evenals in Dengka en Òenale, als partikel van den verleden tijd. Van geringer belangrijkheid is het ontbreken van ndia als aanwijzend voornw., wat overal in Oost-Rotti en ook in Baä voorkomt, (aldaar bezigt 
men ia, ndia (of lia of ria), na en èle, in D. en Òen. alleen ia en $\mathrm{na}$, in $\mathrm{Ti}$ ia, $\mathrm{na}$ en èle), en enkele andere meer. Op zichzelf beschouwd, kan men bij deze feiten evengoed aan invloed van het aan $\mathrm{Ti}$ grenzende Òenale, of het aan Baä grenzende Dengka denken; in verband evenwel met hetgeen boven gezegd is, wijzen zij eerder op een vroegeren toestand.

Overigens draagt ook het dialect van $\mathrm{Ti}$, gelijk reeds gezegd is, een Oost-Rottineesch karakter, en vertoont het verder groote overeenkomst met het Baäsch. Het onderscheidt zich daarvan, behalve door het behoud der oudere $r$ nog door. dien ook eene $\mathrm{nd}$ in het woord, welke in het Baäsch, evenals in het Term. tot $n$ wordt, gespaard is, en doordien de mp in Baä, hier $\mathrm{mb}$ luidt, (mogelijk kan ook het voorkomen van de $\mathrm{mp}$ in Baä, $\mathrm{mb}$ in Ti en ook in Dengka en Òenale, tegenover de $p$ in geheel Oost-Rotti als punt van overeenkomst aangenomen worden; evenwel is in 't oog te houden, dat de $p$ in het Term. enz., gelijk uit de Sprk. zal blijken, uit eene $\mathrm{mp}$, $\mathrm{mb}$ ontstaan moet zijn). Eene groote afwijking schijnt de vorming van den derden pers. enkelv. bij de vervoeging der werkwoorden te zijn; in plaats van $n$ afada, (hij zegt), gelijk in Baä, in overeenstemming met Term., luidt de vorm in Ti ifada; in plaats van namanasa, (hij toont), iminasa, dus met een soort vocaal-harmonie als in Dengka en Òenale.

Uit invloed van deze dialecten, of liever als een overblijfsel uit een vroegeren toestand, meer overeenkomende met dien als aldaar thans nog gevonden wordt, kan deze vorm niet verklaard worden, want ook in D. en Òen. luidt de vorm: nafade, $n$ amanas, en dit is wel altijd zoo geweest, wat daaruit blijken kan, dat ook het Timoreesch hier alleen na bezigt. Ook de $i$ in het prefix, in overeenstemming met wat voorafgaat, wijst niet bepaaldelijk op genoemde dialecten, maar deze neiging moet algemeen Rottineesch zijn, wat daaruit kan blijken, dat zoo het prefix bè, (het eenige, dat een andere vocaal dan $a$ vertoont), vóór een ander prefix gehecht wordt, dit laatste ook in

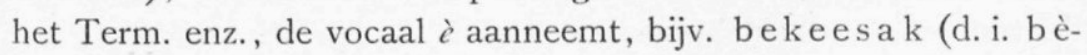
kèesak) ieder één, uit bè en kaesak, enz. Ook is uit het dialect van Ti-zelf, namelijk uit de onregelmatige werkwoorden, te zien, dat dit gebruik van $i$ eene nieuw-vorming is, bijv. naä, hij eet, (oorspronkelijk naá uit 'naká, gelijk uä, ik eet, uit "uá, "uká), evenals in Term. enz. Een gelijksoortig ver- 
schijnsel doet zich evenwel voor in Lòle. Aldaar wordt de 3 pers. enkelv. gevormd door ni, bijv. nitoi doi-n-ala (=Term., Baä natoi doi-n-ala) hij begraaft zijn geld; nielak nò sao-n sò (Term., Baä naelak nò sao-n sò), hij is gescheiden van zijne echtgenoote, of met een prefix: nimilasi (=namalasi)sò, hij is al oud; musu-a nikidedeak (=nakadedeak)sò, de vijand is reeds teruggetrokken; ana ta nimbilani (Term. napalani, Baä nampalani) tao $\mathrm{ndia}$, hij durft dat niet te doen; enz. Daargelaten of $i$ uit $\mathrm{ni}$ is ontstaan, dan wel een zelfstandig element is, zijn beide vormen toch stellig wel gelijkwaardig. Met $\mathrm{Ti}$ heeft het Lòlesch voorts gemeen het behoud van de $\mathrm{nd}$ in het woord, (bijv. banda, dier, Ti idem, Baä bana), alsook dat de $\mathrm{mp}$ in Baä, hier, evenals in $\mathrm{Ti}, \mathrm{mb}$ luidt, (vgl. boven nimbalani, hij durft); voorts het gebruik van enkele bijzondere woorden, als ua (bijv. in: $a u$ aheluk ua-n ana sò, ik heb met hem afgesproken) $=\dot{o}$ in Baä, Term.; numa, enz. (bijv. ai dadi mima nusak esa bela, wij zijn uit dezelfde stad geboortig) $=$ Baä, Term. $\mathrm{n}$ ème, enz. Daarentegen stemt het met Baä overéén, daargelaten dat het eveneens een $l$-dialect is, door het gebruik van sò als partikel voor den verleden tijd, van ndia, als aanwijzend voornw., (gelijk uit de bovenstaande voorbeelden blijkt).

Het vormt dus de verbindende schakel tusschen de tongvallen van Baä en $\mathrm{Ti}$, tevens levert het wederom een bewijs, dat het al of niet gespaard blijven van de $r$ bij de verwantschap geen gewicht in de schaal legt.

Van de Oost-Rottineesche dialecten onderscheidt zich dat van Bilba van het Term. in de eerste plaats, door verdere afslijting. Evenals in het Term. is de $\mathrm{ngg}$ in een woord tot $\mathrm{ng}$ geworden, maar ook vóór aan het woord, waar zij in het Term. gespaard blijft, luidt zij hier eveneens ng. Évenals in het Term. is de $\mathrm{nd}$ in het woord tot $n$ geworden, maar terwijl zij vóór aan het woord in het Term. gespaard blijft, is zij hier overgegaan in $l$. Ten opzichte van de $p$ staat deze tongval, trouwens evenals alle andere Oostelijke dialecten, op hetzelfde standpunt als het Term. Voorts duldt het Bilbasch geen hiaat; waar zoowel in het Term. als in het Bilbasch een medeklinker in het woord verdwenen is, en dit in het dialect van Term. (Baä, enz.) nog blijkt door de hiaat in de uitspraak tusschen beide klinkers, vloeien zij in den tongval van Bilba ineen, bijv. Term. leä, 
vadem, (Mal. dе̌pa), in Bilba lea, en worden gelijke vocalen samengetrokken, bijv. Term. nä̈, hij eet, Bilba n â. De $k$ aan het slot van een woord in Term., (Baä, Ti), als eene echte $k$ uitgesproken, wordt in Bilba tot den ingeslikten medeklinker of slot-hamza, komt echter voor het lidwoord en in andere gevallen weer te voorschijn, bijv. $\mathrm{mane}=$ Term. $\mathrm{mane} \mathrm{k}$ vorst, doch manek-a, de vorst, manek-ala, de vorsten; nggapẹ= Term. nggapek, (wenken), doch a u nggapek ana, ik wenk hem; zoo ook de $k$ in ta-k-asa, (van ta), zij zijn er niet; enz. (ik schrijf steeds naar de afleiding bijv. manek-a, de vorst, dat is mane $\mathrm{k}+a$; voor het Bilbasch zou het eigenlijk beter zijn maneka te schrijven, dewijl de $k$ alleen door de volgende $a$ weer te voorschijn komt; voor de duidelijkheid wordt evenwel de voor het Term. gebruikelijke schrijfwijze behouden). Ook een Termanusche (Baäsche enz.) slot-s gaat over in den ingeslikten medeklinker en komt voor een lidw. enz. wederom als $k$ te voorschijn, bijv. lạ, (honger) $=$ Term. la äs, met lidwoord lak-a, (Term. la äs-a); alleen in de constructie met de telwoorden, enz., als a la volgt, is de $s$ bewaard gebleven, bijv. dua-s-ala, zij beiden, (daarentegen zonder ala: $\mathrm{dua}=$ Term. dua-s). Daartegenover staat, dat in het Bilbasch eene oorspronkelijke $k$ zoowel vóór aan het woord als in het woord, in vele gevallen is bewaard gebleven, waar zij in het Term., (ook in het Baäsch, enz.) ontbreekt. In grammaticaal opzicht onderscheidt het zich overigens slechts in zeer ondergeschikte punten van het Term. Ook in den woordenschat bestaat er weinig verschil; evenwel komen onder de gewestelijke woorden enkele voor, welke nogal een bijzonder karakter dragen, als: dahena, mensch, (terwijl dit in Term., Baä, Ti, ook Dengka en Òenale hataholi of hatahori luidt), ubea of dubea, wat? (Term., Baä, Ti: hata, waar? bè, waar, welk?); enz.

De dialecten van Korbaffo en Bokai staan tusschen het Termanusch en Bilbasch in. Beide hebben met het Bilbasch gemeen den overgang van eene Term. slot- $k$ en slot-s in den ingeslikten medeklinker, welke van het lidw., enz., tot eene zuivere $k$ wordt. In beide is in sommige gevallen de $k$ beter gespaard dan in het Term., bijv. kò, (Bilba idem), gij $=$ Term. $\grave{o}$; kafada, (Bilba, idem), ik zeg; kuä, (Bilba kua), ik eet = Term. a fada, uä; evenwel veel minder dan in het Bilbasch, wel het meest in Bokai. Overigens verschilt het Korbaffosch 
nagenoeg niet van het Term. In Bokai wordt nog in overeenstemming met het Bilbasch eene Term. nd vóór aan het woord tot $l$. In de beneden volgende vertaling blijft eene $\mathrm{ngg}$ vóór aan het woord, (zelfs in het woord, op de wijze van Baä: sangga, zoeken); in de lijst, waarvan in het voorbericht van het Wdb. sprake is, is elke $\mathrm{ngg}$, evenals in Bilba, tot $\mathrm{ng}$ geworden en dit zal wel het juiste zijn, (aangezien ik daarvan evenwel geen volkomen vertrouwbare inlichtingen heb kunnen krijgen, is beneden in den tekst de $\mathrm{ngg}$ behouden). Zooveel is zeker, dat het Bokaisch iets dichter bij het Bilbasch staat dan het Korbaffosch; een hiaat en de uitspraak van twee opvolgende klinkers is evenwel ook in het Bokaisch bewaard gebleven. Ten opzichte van de in het Bilbasch voorkomende woorden van meer bijzonderen aard, als het woord voor "mensch", gaan beide met het Termanusch mede.

De meeste moeielijkbeid voor de classificeering geeft het dialect van Ringgou en wat daarbij behoort. Van de tot dusverre besproken dialecten, Dengka en Òenale buiten rekening gelaten, bleek elk het naast te staan aan dat, wat ook in geographisch opzicht het naast staat: Ti het dichtst bij Lòle, dit wederom bij Baä, dit weder bij Termanu, dit bij Korbaffo en Bokai en deze twee bij Bilba. Te verwachten is dus, dat dit laatste wederom het naast bij het Ringgousch zal staan.

Ten opzichte van de klankverschijnselen kan dit evenwel niet gezegd worden. Wel vertoont het eene $p$ voor de oudere $\mathrm{mp}$ of $\mathrm{mb}$ evenals het Bilbasch, maar dit heeft het gemeen met alle Oostelijke tongvallen. Maar de $k$, welke juist in het Bilbasch zoo menigmaal gespaard is, ontbreekt hier bijna overal, ook waar zij in het Term., enz., nog voorkomt.

Eene oorspronkelijke $\mathrm{ngg}$, in Bilba steeds tot $\mathrm{ng}$ geworden, is hier daarentegen steeds overgegaan in $k$, zoodat bijv. een Ringgousch ka beantwoordt aan een Term. ngga, Bilba. nga, (los), een Ringg. laka aan een Term., Bilba. langa, hoofd, (terwijl in Term., Bilba. ka "bijten», la ka "dwingen» beteekent, welke woorden in het Ringg.: $a, 1$ a ä luiden; eene zekere oefening om dit dialect te verstaan, is dus voor iemand uit een ander landschap wel noodig). In de behandeling van de hiaat in de uitspraak van twee opeenvolgende klinkers, hetzij deze ook in het Term. voorkomt of nieuw ontstaan is door wegvalling van een medeklinker, is dit dialect zeer onregelmatig. 
Eene Term. slot- $k$ is verdwenen, evenals in Bilba, komt zelfs niet voor een lidwoord, enz., te voorschijn; daarentegen is de $s$ als sluiter gespaard. De eenige overeenkomst is, dat eene nd vóór aan het woord, welke in het Bilbasch tot $l$ wordt, in Ringgou (met Òepao) als $r$ te voorschijn komt, (in Landu evenwel blijft, volgens de opgaven van Manafè, de $\mathrm{nd}$ alsdan gespaard). In het woord evenwel, waar de nd van Baä enz., in de Oostelijke dialecten steeds tot $n$ geworden is, blijft zij juist gespaard in het Ringgousch, (en wordt in het Òepaosch tot $r$ ). Ook de eigenlijke grammatica kan weinig opheldering geven, want in groote trekken, (en alleen zóo kan ik over de dialecten spreken), bestaat daaromtrent geen verschil tusschen het Term., Bilbasch en Ringgousch. Toch komen er enkele afwijkingen van ondergeschikt belang voor en daarin gaat het Ringgousch met het Bilbasch mede. Een voorbeeld is het volgende. In eene constructie als: boa ò-fèk-a, (de vrucht, welke gij geeft, de door u gegeven vrucht), wordt de samenstelling van het pronomen $\dot{o}$ (gij) en fè (geven) in het Term. (Baä, enz.) door eene $k$ gesloten, om haar bepaaldelijk als een nomen te kenmerken, dat als adjectief het substantief boak (vrucht) bepaalt, wat dientengevolge de sluitende $k$ verliest; in het Bilbasch ontbreekt echter die toevoeging, zoodat men zegt: boa kò-fè-a, en zoo ook in het Ringgousch: boa ò-f è-a. Maar vooral in de van het Term. afwijkende woorden bestaat er groote overeenkomst tusschen het Bilbasch en Ringgousch; zoo heeft ook Ringg. dahenda (Òep. dahera)= Bilb. dahena, mensch, (elders hataholi, hatahori); Ringg. en Bilba ubea, (Ringg. lubea, Bilb. dubea), wat? (Term., Baä, enz. hata); voorts Ringg., Bilb. bea, waar? (overal elders bè); Ringg. rèn e = Bilb. lèn e, sawah, (Term. Baä enz. hade-òe); Rengg. kaule = Bilb. ngaulẹ, de nationale rondedans, (Term., Korbaffo, Bokai, Baä e ëä, Dengka heka, Oenale ekar); Ringg., Bilb. bolu, weenen, (Term. enz. ki); vgl. voorts het $\mathrm{Wdb}$. Ten slotte staat dan toch van alle andere dialecten het Bilbasch het dichtst bij het Ringgousch, al is de overgang niet zoo geleidelijk als elders.

De hieronder volgende taalproeven bestaan in de eerste plaats uit vertalingen. Het is noodeloos hier uit te wijden over de gebreken, waaraan dergelijke stukken plegen te lijden; doch 
om gemakkelijk een algemeen denkbeeld te verkrijgen van de verschillende dialecten zijn zulke vertalingen van éénzelfde stuk niet ongeschikt; daarenboven is van sommige dialecten geen of weinig ander materiaal aanwezig. De vertaalde stukken zijn de volgende :

De vertalingen in de 9 door Manafè onderscheidene dialecten van de "Hikajat boeroeng anoem dan koera ${ }^{2}$, zijn indertijd voor Holle vervaardigd.

Daarvan bestonden in sommige dialecten twee of drie bewerkingen, welke alle opgenomen zijn. Blijkbaar zijn evenwel niet al die bewerkingen rechtstreeks naar het Maleische origineel gemaakt, maar uit het eene dialect in het andere overgezet. Derhalve is wat bijeen behoort met eenzelfde cijfer van I tot IV gemerkt. Wat onder I en III behoort, is wel oorspronkelijk alleen overgezet in den tongval van Baä, terwijl van IV de Termanusche vertaling de grondslag is geweest; onder II komen er meer voor, welke, onafhankelijk van elkander, naar het origineel zijn vervaardigd, ofschoon ook hier niet alle. Dat het Maleische origineel nu juist zoo geschikt was voor het beöogde doel, althans wat de talen in het Zuid-Oosten van den Archipel betreft, kan niet gezegd worden; vooral sommige bewoordingen, als het herhaaldelijk terugkeerende «toewan hamba», enz., waren zeer geschikt, om het beeld van de taal noodeloos nog meer te bederven, dan dat bij vertalingen toch al het geval pleegt te zijn. Over het algemeen hebben de Rottineesche vertalers, de een meer, de ander minder, zich nog al niet al te slecht door de moeielijkheden heengeslagen. Met behulp van Rottineezen, uit de verschillende landschappen afkomstig, zijn deze vertalingen, zooveel mogelijk van fouten gezuiverd, zoowel in het algemeen als wat meer bepaaldelijk het aan een bepaald dialect eigene betreft, wat voor den eenen tongval gemakkelijker gelukte dan voor den andere, het minst wel voor dien van Bokai en Òenale; de bewerkingen in het Òenalesch waren trouwens bijzonder slecht; blijkbaar waren de drie bewerkers-zelf allen zeer slecht met dit dialect bekend. De bewerkingen in het Baäsch heeft Fanggidaej in orde gebracht en verschillen daardoor het meest van de oorspronkelijke opstelling, zoodat nu niet zoo duidelijk meer blijkt, dat deze de grondslag zijn geweest van al wat met I en III is gemerkt, wat trouwens eene zaak van geheel ondergeschikt belang is. Voorts is alles 
overgebracht in de door mij gebruikelijke schrijfwijze en zijn ook de ontbrekende teekens, (bijv. tot aanduiding van eene hiaat in de uitspraak tusschen twee volgende klinkers, van den ingeslikten medeklinker in sommige dialecten, enz.), door mij, volgens de ontvangen inlichtingen, aangebracht. Het was noodeloos de overbekende Maleische tekst nogmaals te laten afdrukken, daarentegen zijn ter vergelijking ook de bewerkingen in het Termanusch opgenomen, ofschoon voor dat dialect aan dergelijke teksten geen behoefte meer bestaat; (de met II gemerkte, welke oorspronkelijk ontbrak, is naar het Baäsche origineel bewerkt).

Dan volgt eene vertaling in de genoemde dialecten, behalve in het Termanusch, Bokaisch en Òenalesch, van een stukje uit de "Beberapa tjeritera peroepamaän», waarvoor de Termanusche vertaling door Fanggidaej, benevens de Maleische tekst te vinden zijn in Bijdr. XLIV, pag. 668 (onder $\mathrm{N}^{\circ} 10$ ). Met deze vertalingen, waarvan in sommige tongvallen meer dan één opgenomen werden en welke onafhankelijk van elkander ontstaan zijn, is gehandeld als met de vorige.

Ten slotte volgen nog twee vertaalde stukjes in het dialect van Òenale, waarvan de Termanusche vertaling en de Maleische tekst te vinden zijn op blz. 672 (onder $\mathrm{N}^{\circ} 12$ ) en 686 (onder $\mathrm{N}^{\circ}$ 23) van het genoemde deel der Bijdragen; de Termanusche bewerking heeft overigens ook hier geen invloed uitgeoefend. In tegenstelling met de bovengenoemde vertalingen in dit dialect schijnt de taal vrij goed te zijn; meerdere teksten, gesteld in dezen belangrijken tongval, heb ik niet machtig kunnen worden.

Dan volgen de oorspronkelijke stukken, waaronder ook voorkomt wat alleen oorspronkelijk is, in dien zin, dat het niet rechtstreeks vertaald is, in de dialecten van Baä, Ti, Korbaffo, Bilba, Ringgou en Dengka; alsook een stukje in het Òepaosch, (geplaatst achter die in het Ringgousch), benevens eenige spreuken, enz. in de dichtertaal, volgens de uitspraak van laatstgenoemden tongval; men beschouwe deze meer als toegift, aangezien de dichtertaal als een soort kunsttaal voor geheel Rotti dezelfde is; alleen spreekt ieder de woorden naar zijn dialect uit, waarom dergelijke stukken natuurlijk niet kunnen dienen om de dialectische bijzonderheden te doen uitkomen. Met uitzondering van het laatstgenoemde is met deze stukken 
op dezelfde wijze gehandeld als met de vertalingen. Men kan daarbij nu eenmaal niet te werk gaan als met de uitgave van een stuk in de eene of andere litteratuur-taal. Met zeldzame uitzonderingen zijn de opstellers ook al zeer weinig gewend om hunne moedertaal op schrift te brengen, zoodat door het opschrijven allerlei vergissingen, uitlatingen, enz. voorkomen, waarvan de onveranderde wedergave volstrekt zonder eenig nut is. En wanneer het de kennis der dialecten geldt, komt hier nog iets bij; het aantal personen, die geschikt zijn om hulp te bieden, of in elk geval van wie men die geschiktheid en gezindheid daartoe te weten kan komen, is beperkt, en nu kan men soms in een of ander dialect alleen geschreven stukken krijgen van iemand, voor wien dit dialect wel zijne moedertaal is, maar die reeds lang in een landschap, waar men een ander dialect spreekt, gevestigd is; ook doet zich het omgekeerde geval wel voor, dat een stuk opgesteld is door iemand, gevestigd in het landschap, waar de tongval, waarin het geschreven is, gesproken wordt, doch geboortig uit eene andere streek. Ook in dit opzicht moesten wel eens veranderingen aangebracht worden, zoo dit althans mogelijk was; evenwel alleen daar, waar mij overtuigend bleek, dat de verandering ook tevens eene verbetering was, is zij aangebracht, anders is het oorspronkelijke behouden. Van enkele stukken, bijv. van die in het Bilbasch, kan met zekerheid gezegd worden, dat zij een zeer juist beeld van het dialect geven. Ook bij de oorspronkelijke stukken moet erop gewezen worden, dat de aanduiding van de hiaat in de uitspraak, enz., niet in het origineel aanwezig, maar door mij is aangebracht. Omtrent de bijgevoegde vertaling moet de gewone opmerking gemaakt worden: zij is ingericht op het verstaan der stukken; voor zooverre de verstaanbaarheid het eenigszins toeliet, is het oorspronkelijke op den voet gevolgd. Omtrent de stukken-zelf hier nog iets naders te zeggen, valt buiten mijne bedoeling.

Leiden, 12 April 1913. 


\section{VERTALINGEN.}

\section{Dialect van Termanu (Pada).}

I.

Kolobäk-ala lò nggua-dano-a.

Fai makahulu-na-aa dano esa lòle-na nasala, nai dano ndia kolobaök dua lèo lai tale-la dalek. Kolobaök kaduak sila-aa - latiak lò-aa nggua dano esa, dè lèo-lèo-ndia losa-aa fanu-na mai bòe ma-aa dano-a mada-n. Kolobaök kaduak sila-aa lafada nggua-a: "bó tia-ó! afi tao-n ana lèë, òe-dano-a mada-n sò, malòle lenak ita lali teni dano esa teu bai, fò ita sanga ita nanaä-nininu-n. Tè hu ami dale-ma hedis mahani ami laö ela ò. $\mathrm{Hu}$ ndia dè malòle-aa ami mò ò, fò-aa poï ò mu mamana maòek esa, fò ela ami dale-ma-aa loak-a. Ami mae la meni ò tè ami ta mabeï ka lou-ma fa, hu lou-ma matea. Lèo-ndia na ami hoï mala ai esa, fò-aa ò ka mahèle-n neu-aa talada-na ma ami meu peda-n bekeselik, fò-aa ami la meni-ò, tè sadi bòso ò huka bafa-ma poï ai ndia!» Bòe-ma nggua-a natá nae-aa : "emi mae lèo-bè sò na au tunga lèo-ndia». Dè manu-pui-la leni ai kekeük esa dè ala fè nggua-a ka. Bòe-ma kolobaök kaduak-ala leu ai-a peda-n bekeselik, dè-aa la leni-n losa nggòlok esa. Bòe-ma hataholi-la toä lò-n, hu lita nggua-a nai talada ma manu-pui-la lai ki kona-n. Dè basa hataholi sila eki ma totòko lima-n-ala. Bòe-ma nggua-a namanène hataholi sila-aa hala makalupu-n-ala dè nae-aa: "a tè-aa hataholi sila eki hata ndia?» Dè ana huka bafa-na bòe ma-aa ana tuda lèo dae mai dè mate-n. Tutuik ia natèë ndia.

\section{II.}

Tutui nggasa nò nggua dano. ${ }^{1}$

Ala tui lèle ulu-na dano esa malòle-hík. Manu-pui nggasa dua lèo lai talate hu-na nai dano ndia. Nggasa kaduak sila

1 In goed Rottineesch mag hier het lidwoord niet ontbreken; waar dit hier en elders het geval is, is dit navolging van het Mal. origineel.

D1. 68 
latiak lò nggua-dano esa. Lèo lèmek ndia basa dò-na. Bòe-ma fanu-na mai dè dano ndia òe-na mada-n. Boè-ma nggasa kaduak sila kokolak lò sila tia-na lae: "bó tia-ó! dano ia òe-na mada-n sò, faik ia ita tao lèo-bè? Malòle lenak ata lali lèo dano fèëk teu, fò ela ata sanga hapu ita nanaä-na nai ndia. Tè hu au dale-nga hapu totoäk esa, hu au laö ela au lamatua-nga nème ia. Hu ndia dè malòle lenak au ò au lamatua-nga fò poï-n neu mamana maòek esa, fò ela au dale-nga tesa-tama. Tè hu au nau la uni au lamatua-nga, tè ta bòle, hu au lamatua-nga lou-na matea, dè au ta bòle tutu uni-n. Makaneni-ma lèo-ndia sò na au hapu aäfik esa ia: au uni ai esa, fò au lamatua-nga ka neu talada-na. Deï ami dua-ng-ami laü neu ai ndia peda-n bekeselik, tè sadi au lamatua-nga bòso huka bafa-ma!» Bòe-ma nggua- , dano ndia nakaheik nae: "malòle, lamatua-ng-ala lae lèo-bè sò na au tunga leò-ndia.» Bòe-ma nggasa sila leni ai kekeük esa mai, dè nggua-dano ndia ka neu ai ndia talada-na. Bòe-ma nggasa kaduak sila esa na laü neu ai ndia peda-n seli. Dè manu-pui sila la leu losa nggòlok esa bòe ma basa-basa hataholinggòlok ndia lakandá sota, hu lita manu-pui sila-la la lesik ki-kona ma nggua-dano ndia nesik talada. Bòe-ma basa-basa hataholi sila lasanggati ma ala totòko lima-n-ala. Dè nggua-dano ndia namanène hataholi sila eki lasanggati bòe ma natane nae: "basa-basa hataholi sila eki lasanggati hata ndia?» Dè ana bei huka bafa-na kokolak nae lèo-ndia bòe ma ana tuda dae mai dè mate-n. Tutuik ia li-na lèo-ndia.

\section{III.}

Tutui manu-pui anum-ala lò kea-òe-a.

Tutuik ia. Nai lèle makahulu-na-aa dano esa malòle-hík. Ma nai dano ndia manu-pui dua nade anum lèo lai-aa ai «taratai». Ma manu-pui kaduak sila-la-aa latiak lò kea-òe esa. Ma dò baük-a nò dedeäk-a lèo-ndia bòe ma-aa fanu-na mai, dè dano ndia òe-na mada-n. Boè-ma manu-pui kaduak-ala-aa lafada sila tia kea-òe-na: "tia-ng-ò-né, hata dadi ita besak ia fò-aa dano-a òe-na mada-sò-k-ana! Malòle ata lali teu dano fèèk esa, fò ela ata sanga nanaä-t-ala nai na. Tè-aa tòtoäk esa nai ami dale-ma noï sanga laö ela-ng-ò. Hu ndia dé-aa malòle ami mò-ng-ò fò ami poï-ng-ò mu mamana maòek esa, fò ela ami dale-ma loak-a. 
Ma tè ami sanga la mò-ngò, sè, ta bòle, fò ò lou-ma-aa katehík, dè ami ta ka mala fá-n. Ma lèo-ndia sò na-aa ami dedeä-m esa nai ia: muni $^{1}$ ai esa mai, fò ò ka neu ai ndia talada-na ma ami esa na la nesik peda-n esa, tè sadi ò bòö huka bafa-ma nai ai ndia.»

Bòe-ma-aa kea-òe-a natà: "malòle, emi mae lèo-bè na au tunga-tunga mesan». Bòe-ma manu-pui sila-aa la-aa hoï lala ai kekeük esa, dè-aa kea-òe ndia ka nala-n. Boè-ma manu-pui anum-ala-aa la leni-n esa na ai-a peda-n esa. Lèlek ndia manupui-la la losa hataholi nggòlo-n bòe ma-aa basa hataholi-la lakandá lita manadadik ndia, kea-òe-a la nesik talada ma-aa manu-pui dua lesik ki kona-n. Bòe-ma basa hataholi-la-aa lasanggati ma ala totòko lima-n-ala. Ma lèlek ndia kea-òe- anamảnène hataholi-la lahala mue-mue bòe ma-aa natane: "basa hataholi sila-la-aa lasanggati hata». Bòe-ma lèlek ndia ana huka bafa-na bòe ma-aa ana tuda dae mai dè mate-n. Tutuik ia ana tao lèo-ndia.

\section{IV.}

Tutui manu-pui anum-ala lò kea-òe-a.

Fai makaulu-na nai dano malòle esa manu-pui dua nade anum lèo lai-aa ai esa nade tarate lain. Manu-pui kaduak sila-la-aa latiak lò kea-òe esa. Lèo-lèo-ndia dè-aa faik esa bòe ma-aa fanuna mai, dè-aa dano-a mada-n. Bòe-ma-aa manu-pui kaduak-ala-aa lafada sila tia kea-òe-na lae-aa: "bó tia ó! ata tao lèë, fò-aa dano-a-aa mada ndè ia sò, malòle ata huka teu-aa seluk dano esa, fò-aa ata sanga nanaäk nai na. Tè-aa ami dale-ma-aa susa ta hi laö ela-ng-ò. Dè-aa malòle ami mò-ng-ò, fò-aa poï-ng-ò mu mamana maòek esa, fò-aa ela ami dale-ma loak-a. Ma tè ami sanga la mò-ng-ò, sè ta bòle, fò ò lou-ma-aa kate-hík dè-aa ami ta bòle ka mala-n fa. Lèo-ndia na-aa ami mafada-ng-ò fò-aa hoï-má-aa ai kekeük esa, fò-aa ò ka neu-aa ai-a talada-na, fò deï-aa ami dua-ng-ami la meni-ng-ò esa na-aa neu-aa ai-a peda-n seli. Tè-aa sadi ò bòö huka-aa ò bafa-ma!» Bòe-ma-aa kea-òe-a natá: "malòle, emi mae lèo-bè, na-aa au tunga lèo-ndia». Manu-pui kaduak-ala-aa hoï lala-aa ai kekeük esa, dè ala fè-n neu-aa kea-òe-a ka. Bòe-ma-aa manu-pui anum-ala-aa la leni-n esa na-aa neu ai-a peda-n seli. Lèlek ndia ala la losa-aa nggòlok esa bòe ma-aa hataholi-la-aa lakanae lita dè-aa ala heran tao

1 Vertaald als imperatief: breng een stuk hout! 
lèo-bè dè-aa kea-òe esa la nesik talada ma-aa manu-pui dua dè-aa esa la nesik ki ma-aa esa la nesik kona. Dè-aa hataholila-aa lasanggati ma-aa ala totòko lima-n-ala. Bòe-ma-aa kea-òea-aa namanène halak ndia dè-aa natane nae-aa: "basa-basa hataholi sila-la-aa lasanggati hata?». Lèlek ndia ana huka heni-aa bafa-na bòe ma ana tuda lèo dae mai dè-aa mate-n. Tutuik ndia ndè ia.

\section{Dialect van Baä.}

I.

Kolobäk-ala lò nggua-dano-a.

Makahulu-na dano esa lòle-na manaselik; nai dano ndia kolobaök dua lèo lai tale-la dalek. Dè kolobaök kaduak sila latiak lò nggua-dano esa, dè lèo lèmek ndia losa fanu-na mai bòe ma dano-a mada-n. Boè-ma kolobaök-ala lafada nggua-a lae: "bó tola-nò-ó! afi tao-n leò-bè fò dano-a mada-n sò, dè malòle ata lali seluk lèo dano esa teu, fò ata sangga ita nanaä-nininu-n nai ndia. Tè ai dale-ma toä mahani ai laö ela ò. Hu ndia dè malòle ai mò ò, fò ai mpoï-nggò mu mamana maòek esa, fò ela ai dale-ma loak-a. Ai mae la meni ò, tè ai ta ka mabeï ò lou-ma, tò ò lou-ma nèmpek-a. Lèo-ndia na ai haï-mala ai esa , fò ò ka mahèle-n neu talada-na, ma ai meu mpeda-n bekeselik, fò ai la meni-nggò tè sadi ò bòso huka ò bafa-ma mpoï ai-a!» Bòe-ma nggua-a natá nae: "neu, ei mae lèo-bè na au tungga lèo-ndia». Bòe-ma mpuik-ala haï lala ai kekeük esa dè ala fè nggua-a ka ma sila leu ai-a mpeda-n bekeselik dè la leni-n. Dè ala losa nggòlok esa bòe ma hataholi-la lakandá sota hu lita nggua-a nesik talada ma mpuik-ale lesik ki kona-n. Bòe-ma basa hataholi sila eki ma ala totòko lima-n-ala. Dè nggua-a namanène hataholi-la lamue bòe ma natane nae: "basa-basa hataholi sila eki lèo-hatak?» Dè ana huka bafa-na bòe ma ana tuda lèo dae mai dè mate-n. Tutuik ia losa ndia.

II.

Nggasa-1a lò nggua-dano-a.

(Hataholi manasulak nasafali tungga dedeä-kokola-hala-lí Baäk nade M. Toulasik.)

Lèle ulu-na ala tui dano esa malòle hiak. Dè nggasa dua lèo lème dano ndia lai ai lokopòk-ala ma latiak lò nggua-dano esa. 
Dè lèo lèmek ndia basa dò-na. Bòe-ma fanu-na mai dè mada dano-a. Bòe-ma nggasa-la kokolak lò sila tia-na lae: "bó tia-ó, dano ia mada-n sò, dè faik ia ata tao-n lèo-bè» Malòle ata lali lèo dano fèëk esa teu, fò ela ata sangga hampu ita nanaä-na nai na. Tè ai hampu totoäk esa nai ai dale-ma, mahani ai laö ela ò mème ia. Hu ndia dè malòle lenak ai mò-nggò fò ai mpoï-nggò mu mamana maòek esa, fò ela ai dale-ma loak-a. Ai sangga mae la meni-nggò, tè ò lou-ma matea dè ai ta tutu mala-n. Lèo-ndia sò na ai hampu aäfik esa nai ia; ai haï mala ai esa fò ò ka neu talada-na, befik-ò ai dua-nggai mafanggète meu ai-a mpeda-n bekeselik, tè sadi ò bòso ola heni-n. Bòe-ma nggua-dano-a nakaheik nae: "ei mae lèo-bè sò na au tungga lèo-ndia». Bòe-ma nggasa-la haï lala ai kekeük esa dè ngguadano-a ka neu talada-na ma nggasa-la esa na neu mpeda-n seli. Dè mpuik sila-la leu losa nggòlok esa bòe ma basa hataholinggòlok ndia lakandá sota, hu lita mpuik sila la lesik ki kona ma nggua-dano-a nesik talada. Bòe-ma basa-basa hataholi sila lasanggati ma ala totòko lima-n-ala. Dè ngguä-dano-a namanène hataholi sila eki lasanggati, bòe-ma natane nae: "hataholi sila lasanggati hata ndia?» Dè ana bei huka bafa-na kokolak nae lèondia bòe ma ana tuda dae mai dè mate-n. Tutuik ia li-na lèo-ndiak.

\section{III.}

Tutui mpui anum-ala lò kea-òe-a.

Bei-hata-na ala tui ui dano esa malòle-hiak, dè nai dano ndia mpuik dua nade anum lèo lai ai talate-la. Dè mpuik kaduak sila latiak lò kea-òe esa. Dè lèo lèmek ndia dò baü basa bè lèo-ndia, bòe-ma fanu-na mai, dè dano ndia òe-na mada-n. Bòe-ma mpuik kaduak-ala lafada sila tia kea-òe-na lae: "tianggò-né! faik ia hata dadi ita, fò mada dano-a sò. Dè malòle lenak ata lali teu seluk dano fè̈k esa, fò ata sangga nanaäk nai na. Tè ai dale-ma toä, fò mahani ai laö ela ò. Hu ndia dè malòle ai mò-nggò fò ai mpoï-nggò mu mamana maòek esa, fò ela ai dale-ma loak-a. A tè ai mae la mò-nggò bòe, tè fò ta bòle, fò ò lou-ma kate-hiak, dè ai ta ka mala-n. Na lèo-ndia sò ma ai aäfi-m esa nai ia: muni ai esa mai, fò ò ka neu ai ndia talada-na mai ai dua-nggai esa na la nesik mpeda-n esa, tè sadi ò bòso huka ò bafa-ma nai ai ndia!» Bòe-ma kea-òe-a natá nae: "hei, ei mae lèo-bè na au tungga-tungga mesan». 
Bòe-ma mpuik-ala haï lala ai kekeük esa, dè kea-òe-a ka-ná neu talada-na. Bòe-ma mpui anum-ala la leni-n esa na nesik ai-a mpeda-n esa. Dè ala losa hataholi nggòlo-n bòe ma basabasa hataholi sila lakandá sota lita manadadik ndia. Kea-òe-a nesik talada ma mpuik dua la lesik boboa-n bekeselik. Bòe-ma basa hataholi-la lasanggati ma ala totòko lima-n-ala. Dè kea-òe-a namanène hataholi-la mue-mue bòe ma natane nae: "basa-basa hataholi sila lasanggati hata?» Dè ana huka bafa-na bòe ma ana tuda lèo dae mai dè mate-n. Tutuik ia ana tao lèo-ndia.

\section{Lafo-nusak-a nò lafo-nula-dalek-a, (vertaald door O. Nalley).}

Faik esa lafo-nusak esa nahao tia-na lafo-nula-dalek esa; dè ana kalua basa-basa nanaä-nininuk-ala lème mamana-na mai, nanaä-nininu malada ana tao-s leu mamana laok nai hataholi uma-n talada-n. Dè lafo-la dua-s-ala lamahòko lala-n ana seli; tè hu dua-s-ala laä-linu lala talada bòe, ma uma-lamatuak-a mai dè dua-s-ala lalai sudi bebeï-n-ala lèo lafo-nusak-a mamana kekèke-na leu. Dè uma-lamatuak-a laö bòe, ma lafo nusak-a nae tia-na nae: "mai fò deak teu lèon fò teu taä heni ita nanaä-nininu nanaela-n-ala dei!» Tè lafo-nula-a nae: «lèon-a tia, au fali uü-nggau lèo au mamana-ngga nai nula dale $u$; mae nai na au nanaä-nininu-ng selak-a tèbe, kada-kada ai-dòk ma aiokak, tè hu hataholi ta lausik ma ta lakabibík au».

\section{Dialect van $\mathbf{T i}$.}

Korobakok nò nggua-dano.

Fai makahulu-na dano esa malòle hihiek, nai dano na korobakok dua lèo rai tatalek-ara dalek. Korobakok kaduak-ara ratiak rò nggua-dano esa, dè lèo-lèo-ná losa fandu-na mai, bòe-ma dano-a mada-n. Bòe-ma korobakok kaduak-ara rafada nggua-a: "bó tia-lai-ó». duä tao-n lèo-bè, òe-dano-a mada-n ena, malòle ita lali teni dano esa teu bali, fò sangga ita nanaä-nininu-n tè hu ai dale-m-ara ra-sala mahani ai lä ela ò. $\mathrm{Hu}$ na dè malòle ai mò ò fò mboï ò mu mamana maòek esa, fò ela ai dale-mara loak-a. Ai mae lambu meni ò tè ai ta mabeï kiki rou-ma, 
hu rou-ma matea. Lèo-ná na ai haï mala ai esa, fò ò kiki mahère neu talada ma ai meu suü-n bekeserik, fò ai lambu meni ò, tè bòso ò makambò bafa-ma mboï ai na!» Bòe-ma nggua-a natá nae "ei mae lèo-ná ena na au tungga". Dè mbuik-ara reni ai kekeük esa dè fè nggua-a kiki, Bòe-ma korobakok kaduak-ara na reu ai-a suü-n bekeserik dè lambu reni-n losa nggòrok esa. Bòe-ma hatahori-ra toä-n hu rita nggua-a nai talada ma mbuikara rai ki kona-n. Dè basa hatahori na-ra eki ma totòko liman-ara. Bòe-ma nggua-a iminène hatahori na-ra hara mamue-nara dè nae: "bae tòre! basa hatahori na-ra eki hata na?» Dè ikimpò bafa-na, bòe-ma tuda dae mai dè mate-n. Tutuik ia nduku na.

II.

Tutui mbui nggasa nò nggua, (vertaald door J. H. Ohello).

Tutuik ia nai fai bakahulu-n, lilifuk esa lòle-n seli. Nai lilifuk na mbui nggasa dua ara lèo rai dano-mina-r dalek. Dè mbuik kaduak-ara ara tia-lai ro nggua esa. Lèo-lèok-a-ná bòe-ma, timu mai dè mada lilifuk na òe-n. Dè mbuik kaduak-ara rafada sira tia-lain, nggua na, rae: "tia-lai-é, tao lèo-bè ia, mada heni lilifuk na òe-n ena. Malòle ai lali seluk lilifuk fò ai sangga ai nanaä-m nai na. Tè ai dale-m sona, hu ai laö ela tia-lai nai ia. Dè malòle ai mia tia-lai, fò ai mboï tia-lai nai mamana maòek, fò ai dale-m malòle fa. Ai mae lambu mia tia-lai, tè hu tia-lai rou-n matea, dè ai ta tutu mala-n. Buluk-ò lèo-ná, na dedeäk esa nai ia bali, ai meni ai keketuk esa, fò tialai kiki nai ai na talada-n, fò ai dua lambu, esa kiki suü-n bekeesak, tè tia-lai bòso ikimbò bafa-n!» Bòe-ma nggua ana ikiheik nae: malòle, ei mae lèo-bè-ò, au tungga dó.» Dè mbuik kaduak-ara reni ai kekeük esa mai, dè nggua na kiki nai talada-n, ma mbuik kaduak-ara, esa kiki suü-n bekeserik, dè ara lambu losa nggòrok esa. Dè basa hatahori rai nggòrok na, ara heran mète nggua na lambu nai talada ma mbuik kaduak-ara rai boboa-n ki ma kona. Dè hatahori-ra ara randu ma totòko lima-n-ar, bòe-ma nggua-a iminène ara ramue, dè nggua-a sangga itane nae: "hatahori-ra ara randu hata?» Bòe-ma bafa-n ikimbò dè ana tuda neni dae mai, dè ana mate. Tutui-n lèok-a-ná. 


\section{Lafo-uma nò lafo-telas, (vertaald door J. H. Ohello).}

Faik esa lafo-uma esa ihao ndia tia-lai-n lafo-telas esa, dè ana haï basa-basa nanaäk numa mamana-n dea mai, basa-basa nanaäk malada nenesadia-elak nai mamana laok nai hatahori uma-n talada-n. De lafo kaduak-ar na ramahòko ralan seli. Dè dua-s-ar bei raä-raä na tè tenu-uma na mai, dè lafo kaduak-ar na ralai reni nggafak reu dudi rai lafo-uma na ndunu-n. Dè tenu-uma na dea neu bòe, ma lafo-uma na nae ndia tia-lai-n nae: "mai ita dea teu fò taä tabasa ita nanaä-n nenenaä-elak na.» Bòe-ma lafo-telas iselu nae: "lèon-a lèo, au tia-lai-ng, fò au fali au mamana-ng u nai lasi dale; tèbe au nanaä-ng nai na sela-hiek, kada ai dòk-ar ma ai-okak-ar tè hatahori ta rai na, fò ara husi au ma rakatataük au.»

\section{Sosoa-ndandá-n.}

Mète-ma hatahori leò-laö-n nò hòko-dae ao-n tèbe, tè nò masoik ma masodak, bei malòle lena hatahori manggaresi lèòlaö-n nò dale sosonak.

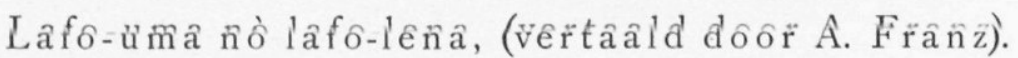

Neu faik esa bòe ma lafo-uma esa ihao tia-lai-na lafo-lena esa. Lafo-uma na haï nanaäk-ara ruma mamana-na, basa nanaä malada-malada-ra ana mbeda-s ara reu mamana malalaok ma masakendik nai hatahori uma-n talada-na. Dè lafo kaduak-ara na dale-n-ara ramahòko rala-n seli, a tè ara bei raä boè ma uma lamatua-n mai dè ara ralai toromu(?) reni lafo-uma na mamana kekèke-n dale reu. Ara nenène ma uma lamatua-n laö dea ${ }^{1}$ neu bòe ma lafo-uma kokolak nò tia-lai-na: "mai ita dea teu tabasa nanaäk fò ita-taä-elak!» Boè-ma lafo-lena natá: "lèon-a, au tia-laí-ng, au fali uni au mamana-ng nai-kada lasi talada-n u, tetèbes-ara nai na au nanaä-ng kada ai-okak-ara ma ai-dok-ara, tè hu nai na, hatahori ta husi ma ta ikitataük au.

Sosoa-ndandá-na, (nekesama-na, nekenesa-na ${ }^{2}$ )

Huk-ara bòe tèbe, mète-ma ita hambu nanaäk nò papakek basafai-n nò dale loak na malòle lena hambu basa-n tesa nò dale totoäk.

1 Dea, in het Term. in deze beteekenis steeds deak.

2 Vgl. Term. nakanenesak, gelijkstellen; voor nekesamak, nekenesak in plaats van nakasamak, nakanesak, vgl. Term. netedò, netehú-n. 


\section{Dialect van Korbaffo (Kolobafo).}

I.

Kolobakok-ala lònggua-dano-a.

Fai makaulu-na dano esa-òo ${ }^{1}$ malòle-hị, nai dano ndia kolobakọ dua lèo lai tale-la dalẹ. Kolobakọ kaduạ sila latiạ lò-òo nggua-dano esa, dè lèo-lèo-ndia losa-òo fanu-na mai, bòe-ma-òo dano ndia mada-n. Kolobakọ kaduạ sila lafada nggua-a: "ó tiang-ò-nó, afi tao-n ana lèë; òe-dano-a meti-n ndia ${ }^{2}$ sò. Malòle lenạ ita lali selụ lèo dano esa teu bai, fò-òo sanga ita nanaänininu-n. Tè hu ami dale-ma hedik-a, mahani ami laö ela kò. $\mathrm{Hu}$ ndia dè malòle lenạ ami mò kò, fò-òo poï kò mu mamana maòẹ esa, fò ela ami-òo dale-ma loak-a. Ami mae-òo la meni kò tè ami ta mabeï ka lou-ma fa, hu lou-ma teak-a. Lèo-ndia na ami haï mala ai esa, fò-òo kò ka mahèle-n neu talada-na, ma ami meu peda-n bekeselị, fò-òo ami la meni kò, tè sadi bòö kò huka bafa-ma poï ai ndia!» Bòe-ma-òo nggua-a natá nae: "kemi mae lèo-bè na au tunga ,lèo-ndia." Dè manupui-la ${ }^{3}$ lemi ai kekeü esa, dè-òo fè nggua-a ka. Bòe-ma kolobakọ kaduak-ala leu ai-a peda-n bekeselị dè-òo la leni-n losa nggòlọ esa. Bòe-ma hataholi-la toä lò-n, hu lita nggua-a nai talada ma manu-pui-la lai ki kona-n. Dè basa hataholi sila eki ma-òo totòko lima-n-ala. Bòe-ma nggua-a namanène sila-òo hala makalupu-n-ala dè nae-òo: "na basa hataholi sila eki lèo-hatạ?" Dè huka bafa-na, bòe-ma-òo tuda lèo dai mai dè mate-n. Tutuị ia natèë ndia.

II.

Tutui nggasa nò nggua-dano, (vertaling van S. J. Manubulu).

Ala tui dò lafada lae: nai ai dò tèpo makaulu èle-a, dano esa lòle-na hata. Nai dano ndia nggasa dua lèo lai nanapak-ala lain, latiạ lò nggua-dano esa. Bana sila telụ latiạ lèo-ndia losa hanak-a mai, bòe-ma mada dano ndia òe-na. Lèo ndia bòe ma nggasa sila duạ lafada sila tia nggua-dano-n ndia lae: "bó tiang-ò, besạ ia ita hoï tao-n lò-bè, dana ia òe-na mada sò. Leòndia malòle lenạ ami lali lèo dano fèẹ meu, fò ela ami sanga

1 Ò o of ò (lang gerekt)= Term. a a.

${ }^{2} \mathrm{~N}$ dia voor $\mathrm{ndi}-\mathrm{ia}=$ Term. ndè ia.

3 Volgens Manafè zou men in Korbaffo zeggen: manu-puik-ala. 
hapu nanaä nai na. Tè hu totoạ esa nai ami dale-m-ala laö ela kò mème ia, hu ndia malòle lenạ ami meni kò fò poï-ngò mu mamanạ esa maòẹ, fò ela ami dale-m-ala hapu sodạ. Tè besạ ia ami ta la meni kò fa hu kò lou-ma balakaik-a, dè ami ta ka menị ami nggonggòlo-m-ala. Lèo-ndia na bei kekedị esa, ami meni ai esa, fò kò ka mu ai ndia talada-na, fò ela ami la meni kò, esa-esa nesị peda-n seli, tè kò sadi bòso huka bafa-ma nème ai ndia mai!» Nggua-dano ndia namanène lèondia, bòe-ma natá nae: "malòle besạ ia kemi mae lèo-bè na au tunga-n lèo-ndia.» Bòe-ma nggasa sila duạ leni ai esa, dè nggua-dano ndia ka neu talada-na, lèo-ndia manu-pui sila-la esa-esa nesị peda-n seli. Manu-pui sila-la la lèo-ndia losa nggòlọ esa; bòe-ma basa hataholi-la lai nggòlọ ndia dalẹ lakatoä-n nggua-dano-a la nai manu-pui dua talada, esa nesị ki ma esa nesị kona. Lèo-ndia basa hataholi sila eki ma totòko lima-n-ala. Nggua-dano ndia namanène basa hataholi sila hala-n-ala, bòema ana nafada nae: "tè hataholi sila eki lèo-hatạ ndia?" Ana hoï huka bafa-na, bòe-ma ana tuda lèo dae-inak-a mai dè mate-n. Tèbẹ lèo-ndia tutuị ndia.

Tutuị nème lafo-aek-a nò lafo-fuik-a, (vertaald door S. Ndun).

Nai faị esa bòe ma lafo-aẹ esa nahao tia-na lafo-fuị esa naä. Bòe-ma ana kalua nanaäk-ala lème mamana-na mai, manaä sila-la manaä malada-malada nai mamana malòle nai hataholi uma-n dale. Lafo kaduạ sila lamahòko-lá-n seli, tè hu sila laälá-n losa talada, bòe-ma manò-umak-a mai. Bòe-ma lafo kaduạ sila alai-lá-n seli lèo lafo-aek-a ndunu-na leu. Dè manò-umak-a kalua, boè-ma lafo-aek-a nafada tia-na nae: "mai ita kalua, fò tao heni ita nanaä-ela-n-ala!» Boè-ma lafo-fuik-a natá nae: "lèon-a tia, au kuüi-ng lèo au mamana-ng manai nula-dalek-a; nakalena ${ }^{1}$ hoï nanaä-nga nai ndia-a ${ }^{2}$ selak-a, hoï ${ }^{3}$ ai-dò-nula-a nò oka-samụ, tè hu hataholi ta lausị dò lakabibị au.

\section{Sosoa-ndandá-na.}

Tèbe léo-ndia nanaä selak-a, makaneni-ma nò soda-mòlek-a ma tetu-tema-n lena heni ndela-saäk-a nò dale pute-kaik-a.

1 Nakalena, verklaard door "sungguh", vgl. Sumba. lănga-tăka, idem.

2 $\mathrm{Ndia}=$ Term. ndia-é, gelijk boven èle-a = Term. èle-é.

s $\mathrm{Ho} ̈=\mathrm{R}$ noi, slechts. 


\section{Dialect van Bokai.}

I.

Kolobakok-ala lò nggua ${ }^{1}$-dano-a.

Fai makaulu-na dano esa lòle-na nasala, nai dano lia kolobakọ dua lèo lai tale-la dalẹ. Kolobakọ kaduạ sila-aa latiạ lò nggua esa, dè lèo-lèo-lia losa-aa fanu-na mai, bòe-ma-aa dano-a mada-n. Bòe-ma-aa kolobakọ sila-aa lafada nggua-a: "ó tia-ngg-ò-nó! duä tao-n ana lèë, òe-dano-a mada-n lè ia sò. Malòle lenạ ita lali selụ lèo dano esa teu bai, fò-a sangga ${ }^{2}$ ita nanaä-nininu-n. Tè hu ami dale-ma hedik-a mahani ami laö ela kò. Hu lia dè malòle lenạ ami mò kò fò-aa poï kò mu mamana maòẹ esa, fò ela ami dale-m-ala loak-a. Ami mae la meni kò, tè ami ta mabeï ka lou-ma $\mathrm{fa}$, hu lou-ma nèpek-a. Lèo-lia na ami haï mala ai esa, fò-aa kò ka manèpe-n neu talada-na, ma ami meu peda-n bekeselị, fò-aa ami la meni kò, tè sadi bòö kò huka bafa-ma poï ai lia!» Bòe-ma-aa nggua-a natá nae: "kemi mae lèo-bè na au tungga ${ }^{3}$ lèo-lia. Dè manu-pui-lía leni ai keketụ esa dè fè nggua-a ka. Boè-ma kolobakọ kaduạ sila leu ai-a peda-n bekeselị dè la leni-n losa nggòlọ ${ }^{4}$ esa. Bòe-ma hataholi-la lakatoä-n hu lita nggua-a nai talada ma manu-pui-la lai ki kona-n. Dè basa hataholi sila eki ma totòko lima-n-ala. Bòe-ma nggua-a namanène sila hala makalupu-n-ala dè nae: "na basa hataholi sila eki lèo-hatạ? Dè huka bafa-na bòe ma tuda lèo dae mai dè mate-n. Tutuị ia natèë lia.

\section{Dialect van Bilba (Belubá).}

I.

Kolobakọ nò ngua-dano.

Fai makahulu-na dano esa lòle-na, nai dano lia kolobakọ dua lèo lai tale-la dalẹ. Kolobakọ kaduạ sila latiạ lò ngua esa, dè lèo-lèo-lia losa fanu-na mai, bòe-ma dano-a meti-n. Bòe-ma kolobakọ sila duạ lafada ngua-a: "ó tia-ng-ò-nó, afi tao-n lèo-

\footnotetext{
1 Zoo of ngua?

2 Zoo of sanga?

3 Zoo of tunga?

4 Zoo of ngòlọ?
} 
bea òe-dano-a meti-n ana lia ia sò, malòle lenạ ita lali lèo dano esa teu bali, fò sangi ita naná-nininu-n. Tè hu ami dale-m-ala hedik-a mahani lako kela kò. $\mathrm{Hu}$ lia dè malòle lenạ ami mò kò fò poi kò mu mamana maòe esa, fò kela ami dale-m-ala loak-a. Ami mae la meni-ngò tè ami ta mabeki ka lou-ma fa, hu lou-ma mèpek-a. Lèo-lia sò na ami hai mala kai esa, fò kò ka mahèle-n neu talada-na ma ami meu peda-n bekeselị fò ami la meni-ngò, tè sadi bòso kò huka bafa-ma poi kai lia!» Bòe-ma ngua-a natá nae: "kemi mae lèo-bea sò na au tunga lèo-lia. Dè manu-puik-ala leni kai keketụ esa dè fè ngua-a ka. Bòe-ma kolobakọ kaduạ sila leu kai-a peda-n bekeselị dè la leni-n losa ngòlọ esa. Bòe-ma dahena-la toka lò-n, hu lita ngua-a nai talada ma manu-puik-ala lai ki kona-n. Dè basa dahena sila eki ma totòko lima-n-ala. Bòe-ma ngua-a namanène dahena-lah hala napue-n sila dè nae: "na basa dahena sila eki dubea?» Dè huka bafa-na bòe ma tuda lèo dae mai dè mate-n. Tutuị ia natèke lia.

II.

Tutui manu-pui ngasa nò ngua. (Manatui nasafali tutuị ia tunga dedeạ dò hala-lí dahena Bilba, Diu, Lelenuk ma Bokai (sic) nade A. Thei).

Nai lèle makahulu-na dano esa malòle seli-n. Nai dano lia manu-puị dua, nade ngasa, lèo lai lia lai kai tale-la hu-n-ala. Manu-puị sila duạ tao tiạ lò ngua esa lèo nai dano lia dalẹ-a. Bòe-ma hana-ina mai, dè dano lia òe-na mada. Bòe-ma manupuị sila duạ lafada sila dua tia ngua-na lae: "bó tia! besạ ia au tao lèo-bea, hu òe dano lia mada sò. Malòle au lali ku selụ dano maòẹ, fò au sanga nanạ́ nai lia, tè totokạ esa nai au dale-nga, hu ta hi lako kela lamatuak-a fa. Hu lia dè malòle ata-ma la nò lamatuak-a, fò poi neu mamana maòẹ, fò kela ata-ma dale-na loạ. Tè hu ata-ma ta nabeki la nò lamatuak-a, hu lamatuak-a lou-na mèpẹ seli-n, dè ata-ma ta seu nala-n. Buluk-a lèo-lia na dedeạ esa ia: ata-ma neni kai esa, fò lamatuak-a ka neu kai lia talada-na ma ata-m-ala esa seu neu kai lia peda-n seli ma esa seu neu peda-n seli fò la, tè bòso lamatuak-a huka bafa-na poi kai lia!» Bòe-ma ngua-a nata nae: "malòle, lamatuak-a nae lèo-lia na ata-ma tunga ". Bòe-ma manu-puị sila duạ seu leni kai ngengèlọ esa, dè nggua-a ka neu 
kai lia talada-na ma manu-puị sila duạ esa seu neu kai lia peda-n seli ma esa seu neu peda-n seli dè la. Fạ̣ lia la leu losa ngòlọ, dahena lelèo-n, dè basa dahena-la lai ngòlọ lia toka-n hu lelu lita ngua lia la nesị manu-puị sila duạ talada-n ma manu-puị sila duạ esa nesị ngua-a ki-na ma esa nesị kona-na. Basa dahena sila eki ma totòko lima-n-ala. Bòe-ma ngua-a namanène hala dahena manaekị dò masangatị sila dè nafada nae: "basa dahena sila eki dò lasangati dubea?» Bei huka bafa-na, bòe-ma tuda lèo dae neu dè mate-n. Tutuị lia li-na lèo-lia.

Lafio-uma-a nò lafo-nula-a, (vertaald door N. Lona).

Nai faị esa lafo-uma esa hao tia-na, lafo-nula esa, dè òfe nala naná malada ai-ain peda-n neu mamana mangamoị nai uma esa dalẹ, dè lâ linu lamahohòko ao losa talada, bòe-ma uma-a lamatua-na mai, bòe-ma dua-s-ala fenga lèo lafo-uma-a mamana fufuni-n dale leu. Bei uma-a lamatua-na dea neu bòema lafo-uma-a nafada tia-na nae: "mai teu ta heni ita nanánininu-ela-n-ala lèon!» Bòe-ma lafo-nula-a nafada tia-na nae: "tia, malòle-a au fali sụ lèo nula dale ku, tèbe au naná-nininu-ng takadalụ seli-n, ${ }^{1}$ noi kai-dò ma kai-okạ, tè hu dahena ta usi dò lakatatakụ au fa».

\section{Dialect van Ringgou, (Rainggou, Lainggou of Raikou).}

II.

Tutui manu-pui kasa nò kua-dano. (Manatui

nasafali tuka dedea Ròte hara-lí

Raikou E. J. Fakie.

Nai lèle maulu-na manu-pui kasa dua lèo rai tale-dano-ra hu-n-ara, rai dano malòle-ina esa dalẹ. Manu-puị sira dua-s ratiạ rò kua-dano esa manalèo nai dano na dalẹ bòe. Telu-s-ara

1 In seli-n (vgl. ook hierboven II) staat het subject achteraan, terwijl het Term. an a seli bezigt In het Term. moet tevens het voorafgaande adjectief in substantief-vorm staan, terwijl het hier adjectief blijft. Naast seli-n komt ook voor naseli-n, (vgl. beneden het eerste en laatste verhaal; sommigen beschouwen dit als het juiste), dit voorafgaande $\mathrm{na}$ is wel oorspronkelijk het pronominale aanhechtsel geweest, behoorende bij het voorafgaande woord, al moge deze constructie, gelijk die in het Term. in zwang is, ook hier nog voorkomen, (vgl. beneden in het eerste verhaal maka dèsena seli). 
ratiạ losa hanas-a mai bòe ma, meti dano na òe-na. Bòe-ma manu-pui kasa dua-s hule ${ }^{1}$ ratá dua-s tia kua-na ma rae: "ò tia-ó, dano ia òe-a meti-n sò, dè ami tao lèo-bèa? Ami moi lali ela dano ia fò meu saka selụ mamana maòe fò ela ami ue ami tei-m-ara na hapu. Tè hu ami dale-m-ara toä mò laö ela ò mesa-kò mahani dano ia dalẹ. Hu na dè afi mae la mò-kò, fò poi-kò mu selụ dano maòẹ dei fò ami laö ela-kò mò dale loạ. Tè hu ò rou-ma beraäị-a, dè ami ta seu malelạ neu rou-ma fò la mò-kò fa. Hu na dè ami mala aäfị esa nai ia: ami meni ai esa mai, fò ò a neu ai-a talada-na ma ami dua seu neu ai-a peda-n beësạ fò la mò-kò, tè sadi maneni-ma a mala sò na bòso huä bafa-ma ela ai-a bali!» Bòe-ma kua-a natá ma nae: "malòle-a, emi dua mae lèo-bea na au atá tuka lèo-ná bòe. Bòe-ma tia kasa-n dua-s reni ai eëtụ esa neu, dè fè kua-a a neu ai-a talada-na, ma kasa dua-s seu neu ai-a peda-n beësạ, dè la rò tia kua-na. La dè reu raráa ${ }^{2}$ rò kòro esa bòe ma, kòro na lahenda ${ }^{3}$-n-ara dale-n-ara ratoä-n hun rita kua-dano na la nesị talada ma manu-pui kasa dua-s esa la nesị kua-a pò i-na ma esa nesi. à̀ ona-na. $\mathrm{Hu}$ na dè basa kòro na lahenda-n-ara heï dò rasakati fò totòö lima-n-ara. Bei kua-a namanène heheïsara na bòe ma nae natane tia kasa-n-ara nae: "basa lahenda sira heï dò rasakati ubea?» Kua-a bei nae huä bafa-na fò dedea dò natane lèo-ná bòe-ma, bafa-na huä ela ai-a, dè tuda lèo dae-a mai dè mate-n. Tutuị na li-na lèo-ná.

\section{III.}

Tutui manu-pui anum nò ea-òe.

Fai ulu-na nai dano malòle esa manu-puị dua nade anum lèo rai ai esa, nade tarate, lain. Manu-pui kaduạ sira ratiạ rò ea-òe esa. Lèo-lèo-ria dè fai esa bòe-ma fandu-na mai dè dano-a mada. Bòe-ma manu-pui kaduạ-ara rafada sira tia ea-òe-n rae: "ò tia, ata tao lèo-bea, fò dano mada ria ia so, malòle ata huä teu selụ dano esa, fò ela ata saka nanạ́ nai na. Tè ami dale-ma

${ }^{1}$ Hule, beteekent hier, roepen (vgl. Term. nòke), hule natá, roepen en antwoorden, na geroepen te hebben antwoorden = het woord tot iemand richten.

2 Rará=Term. ndandák, in de richting van.

${ }^{8}$ Lahenda in plaats van dahenda (mensch) als sub III en IV schijnt meer tot het dialect van Landu te behooren. 
susa ta hi laö ela ò. Dè malòle ami mò ò fo poi o mu mamana maòẹ esa, fò ela ami dale-ma loạ. Tè noi saka mò ò, ta bòle fa, fò ò rou-ma ate-hị, dè ami ta bòle a mala-fá-n. Lèo-ria na ami mafada ò fò hai-má ai eëtụ esa, fò ò a neu ai talada-n, fò dei ami dua la meni ò, esa na neu ai-a peda-n seri. Tè sadi ò bòso huä ò bafa-ma!» Bòe-ma ea-òe-a natá : "malòle, emi mae lèo-bea na au tuka lèo-ria.» Manu-pui kaduạara hai rala ai eëtụ esa, dè fè-n neu ai-pedạ seri. Lèlẹ ria ara la losa kòro esa bòe ma dahenda-ra rakanae rita dè ara heran tao lèo-bea dè ea-òe esa la nesị talada ma manu-puị dua dè esa la nesị i ma esa la nesị ona. Dè dahenda-ra rasakati ma ara totòö lima-n-ara. Bòe-ma ea-òe-a namanène harạ ria dè natane nae: "basa dahenda sira rasakati hata?» Lèlẹ ria huä heni bafa-na bòe ma tuda lèo dae mai dè mate-n. Tutụ ria ri ia.

\section{IV.}

Tutui manu-pui nò ea-dano.

Tutuị ia, nai lèle maülu-n dano esa malòle-hị. Ma nai dano ria manu-puị dua, nade anum, lèo rai ai tarate. Ma manu-pui kaduạ sira-ra ratiạ rò ea-dano esa. Ma dò-na nasala nò dedeạ-a lèo-ria bòe ma fandu-na mai dè dano ria òe-na meti. Bòe-ma manu-pui kaduạ-ara rafada sira tia ea-dano-n ria: "tia-ó, ata tao lèo-bea fò besạ ia dano ria òe-na meti sò! Malòle ata laö teu selụ dano fèe esa, fò ela ata saka nanạ nai na. Tè sosotạ esa nai ami dale-ma saka laö ela ò. Lèo-ria na malòle ami mò ò fò ami poi ò mu mamana maòẹ esa, fò ela ami dale-ma loạ. Ma tè ami moi saka la mò ò ta bòle, fò ò rou-ma ate-hị, dè ata ta mala fá-n. Lèo-ria na ami dedea-m esa nai ia: meni ai esa, fò ò a neu ai ria talada-n ma ami la esa na neu pedạ esa, tè sadi ò bòso huä bafa-ma nai ai ria!» Bòe-ma ea-dano-a natá: "malòle emi mae lèo-bea, au tuka.» Bòe-ma manu-puị sira-ra hai rala ai eëtụ esa dè ea-dano ria a nala-n. Bòe-ma manu-pui anum-ara la reni-n, esa na pedạ esa. Lèlẹ ria manupuị-ara la losa dahenda kòro-n, bòe-ma basa dahenda-ra reu rita manadadị ria ea-dano-a la nesị talada ma manu-puị dua lesị pò i ona-n. Bòe-ma basa dahenda-ra heï ma ara totòö lima-n-ara. Bòe-ma lèlẹ ria ea-dano-a namanène dahenda-ra rapue, bòe-ma natane: "basa dahenda sira hei hata?». Bòe-ma lèlẹ ria ana huä bafa-na, bòe-ma tuda lèo dae mai dè mate-n. Tutụ̣ ia dadi tao lèo-ria. 


\section{Lafo-uma-a nò lafo-nura-a, (vertaald door J. A. Thei).}

Faị esa lafo uma-dalẹ esa nahao tia-n lafo nura-dalẹ esa, dè hai neni basa naná malada ma balaminạ '-ara rème mamana-na mai dè peda-s reu mamana makamoị ma makadilạ nai lahenda uma-n dalẹ. Tia-lai kaduạ sira ramahòö-rá-n manaselị, tè dua-s bei râ-râ bòe ma manò-umạ-a lèo uma dale neu; bòe-ma dua-s èdo, (fekar) lèo lafo-uma-a mamana fufuni-n dale reu. Bei manòumạ-a dudi deạ neu bòe ma lafo-uma-a nae tia-na nae: "mai deạ teu tao heni naná-nininụ fò ita-bei-ta-tinu-ela-a!» Bòe-ma lafo nura-dalẹa sipo mae nae: "lèon-a tia! au u-kau lèo nura dale u, tetèbes-ara nai na naná-nininu selạ-ara; ria: ai-dò ma ai-okạ, tè hu lahenda ta usi dò natataü-kau fa.

Lafo-uma (-aẹ, -iku) nò lafo-nura (-fuị, -dea, -telas), vertaald door E. Fakie.

Faị esa dè lafo-uma esa nalò tia-n lafo-telas esa fò reu uma-n râ, dè lafo-uma-a ana hai basa naná malada-ra rème mamana fufuni-na lèo deạ reu, dè nalalau-s reu mamana makamoi nai lahenda uma-n ten-dale-n. Dè tia-lai kaduạ sira ramahòö-rá-n padoạ-a, tè hu dua-s bei râ-râ, bòe-ma maumạ-a ana mai; bòema lafo dua-s lèo dè ralai ratitika uạ reu dè rala lafo-uma-a mamana-fufuni-n dale. Bei maumạ-a ana fali lèo deạ neu-n selụ, bòe-ma lafo-uma-a nafada neu tia-n lafo-telas-a nae: "mai ita lèo deạ teu fò tâ tabasa ita naná manamalai ${ }^{2}$-ela-n-ara!» Bòema lafo telas-a ana selu: "lèon-a, tia-kò-n au fali rò-rò ${ }^{3}$ lèo mamana-k-a u nai lasi talada, tetèbes-ara au naná-k-a nai na balasela padoạ, na-na ${ }^{4}$ : ada noi ai-dò-a ma ai-oka-a mesan, tè hu lahenda ta usi ma ratataü-kau.

Rará-na.

Deta lèo-ná tèbe manahèlo-a ana hèlo nae uni: "lada nae-dò lasi-a, mina òe apa-tei-a, funu-òle Ròte boa-na, aba-dai Hèlo

1 Of dergelijke vormen met $l$ in plaats van $r$ juist zijn, is onzeker.

${ }^{2}$ Manamalai-ela beteekent: die iets snel wegloopende verlaat; er wordt hier evenwel van het voedsel gesproken dat op deze wijze achtergelaten wordt, de vorm moet dus eigenlijk zijn $\mathrm{n}$ a n a na la i-elạ, een sterk voorbeeld dus van de verwarring van de mana-en nana-vormen.

3 Rò-rò $=$ Torm. nd ò-nd ò.

4 Na-na=Term. ndè ndia, uit ndiandia, (dat is het), staat gewoonlijk achteraan in den zin. 
pena-na, dèke ai dèle-fuị-a ma mata-bulu pòe-saụ-a, maneni-ma nò dale-sodạ ma tei-mòlẹ na lòle-na lena heni lada hade mòdopeda-a, mina tua-òe beụ-a, kèo kakama suta-a, pila beudae lusi-a, pila seda-sada sina-a ma mananòe nao oli-a, maneni-ma nò dale-sikọ ma tei-salạ».

De zin van deze toepassing (rarạ $=$ Term. ndandák) is:

Zoo zingt naar waarheid de dichter: de smaak van nae-dò (soort slingerplant, waarvan de bladeren soms als groente gegeten worden) uit het woud en van oud, bedorven kokos-vocht; de vrucht van Rottineesche funu-òle, (soort plant, in het Term. mòdo-kapa-òek, in het Mal. van Koepang kolengof kolon-susu genoemd, die een soort wol oplevert, welke meer bepaaldelijk in het Term. funu-kòle genoemd wordt, doch niet geschikt is om er kleeren uit te maken), en van de Koepangsche aba-dai, (soort kapas, waarvan de wol eveneens onbruikbaar is); de pit van de wilde dèle-plant en de voelhoorns van de pòe-saụ, (soort kreeft), indien het (genoemde) gepaard gaat met heil en vrede, is beter dan de smaak van rijst als het uiteinde van de plant geel wordt, (jonge, juist rijpe rijst), en van versch lontar-sap, de zwartheid van zijde en de roodheid van fluweel, de glans van chineesche kralen en versmolten Japansch (?) goud, indien dat gepaard gaat met ongeluk en oneenigheid.

Lada nae-dò lasi-a, staat voor wat in de gewone taal zou luiden nae-dò-lasi-a lada-na; evenzoo dèke dèle-fuị-a voor dèle-fuị-a dèke-na; het is mogelijk, dat de vrijheid om op deze wijze den genitief uit te drukken, in de taal der dichters, waar dat in de gewone taal niet kan, overgebleven is uit den vroegeren toestand, maar zekerheid bestaat daaromtrent niet, het kan evengoed eene dichterlijke vrijheid uit lateren tijd zijn, in navolging van zulke samenstellingen, waarin het bepalende woord volgt, welke in eene eigenlijke genitief-constructie ontbonden kunnen worden. Meermalen toch is eene in gedichten voorkomende constructie stellig niet de oorspronkelijke. Min a (Term. minak) is hier gelijk aan la dạ, ( $\mathrm{ladak}$ ) wegens het parallellisme. Òe a pa-tei $\mathrm{i}$ mina a pa-tei (Term. mina kapa-tei), "olie als buffel-drek», bedorven klapperolie. Wat zulke woorden als kakama, beudae eigenlijk beteekenen, weet niemand; zij komen alleen in eene dergelijke uitdrukking Dl. 68. 
voor; men is eigenlijk niet eens zeker, dat de vorm goed overgeleverd is, dewijl meerdere woorden, meermalen zeer ver schillend in vorm, door verschillende personen in het geheugen worden bewaard. Dit geldt ook voor $\mathrm{n}$ a o, waaraan de beteekenis "goud» wordt gehecht. Oli (Term. koli), staat in gedichten steeds naast Sina; of de beteekenis: Japan, welke de schrijver er aan toekent, juist is, is wel meer dan twijfelachtig; soms wordt Sina dò Koli opgegeven als naam van eene plaats buiten Rotti, bijv. als oude benaming van Atapoepoe. Of men moet schrijven bijv. dèle fuị-a (三 dèle-fuik-a) of dèlefui-a is in dit dialect onzeker, dewijl in de dichtertaal, (hier stellig een ouderen toestand vertoonende), dikwijls de slot- $k$ ontbreekt, waar zij in de gewone taal regelmatig voorkomt.

\section{Dialect van Dengka, (Dengga).}

I.

Kolobaö nò nggua-dano.

Mia fai maähulu-na dano esa lòle-na manaselị, sia dano na kolobaọ lua lèo sia tatales-elu lalạ. Kolobaọ kaluạ-elu na-la latiạ lò nggua-dano esa, ona-ona-ná losa fandu-na nea, bòe-ma dano-a meti-n. Bòe-ma kolobaọ kaluạ-elu na-la lafada nggua-a: «tia-lai ói; duduä tao ona-bè, òe-dano-a meti-n ena; malòle hita lali selụ dano esa teu fai, fò sangga hita naná-nininu-n. Tè hu hai lala-m-ala mela muhani lao hela hò. $\mathrm{Hu}$ na dè malòle hai mò hò fò mboï hò mu mamana maòẹ esa, fò hela hai lala-m-ala lamaloa. Hai mae lambu mendi hò tè hai ngga mabeï iï lou-ma, hu lou-ma manggatẹ. Ona-ná na hai haï mala hau esa, fò hò iï muhèle neu kalada-na ma hai mi su-n beëselị, fò hai lambu mendi hò, tè sadi afị hò mutumbò bafa-ma mboï hau na!» Bòe-ma nggua-a natá nae: "hei mae ona-bè na au tungga.» Dè mbuị-elu na-la lendi hau eëkụ esa, dè fè nggua-a iï. Bòe-ma kolobaọ̈ lua-n-ala leu hau-a su-n beëselị dè lambu lendi-n, losa nggòlọ esa. Bòe-ma hataholi-la toä lò-e, hu linda lita nggua=a sia kaladạ ma mbuị-elu na-la sia di ona-n. Dè hataholi-elu na-la landu ma totòö lima-n-ala. Bòe-ma nggua-a namanène hataholi-la hala mamue-n-elu na-la dè nae: "auáh , hataholi-elu na-la landu sa?» Dè huä bafa-na bòe ma eni lae nea dè mate. Duduit ia losa na. 
II.

Dudui mbui nggasa nò nggua, (neneduị nasabali-n neu dedea Lòte hala-lí Dengga).

Sia fai dala-hulu-na dano esa malòle manaselị. Sia dano na lala-na mbui nggasa lua lèo tatalẹ-ala hu-n-ala. Mbui nggasa kaduạ-elu na-la latalaị lò nggua esa manalèo sia dano na lalạ bòe. Mbui kaduạ-elu na-la lò nggua na telu-n-isi latalạ̣ basa lèlo-faị baü-bè bòe-ma hana-ine-a nea dè mada etu dano na òena. Bòe-ma mbui kaduạ-elu na-la lòë-latá ${ }^{1}$ sila tia-lai nggua-na ma lae: "wah lai-á, meti hendi dano-a òe-na dè hai tao ona-bè? Malòle lenạ hai lali selụ mi dano maòẹ fò hai lèo nggè-m-ala dò ue-tei-m-ala sia na. Tè hu hai lala-m-ala toä laö hela hò mesa-nggò muhati dano mada ia lala-na. Hu na malòle lenạ hai mò hò fò mboï hò mu mamana maòẹ fò̀ hai lala-m-ala tesa ma tama. Tè hu hai ngga bòle bido hai nudu-m-ala leu hò lou-ma a-fa hu manggatẹ manaselị dè hai ngga bòle mitimbèle mò hò a-fa. Buluk-ò ona-ná, na hai afi mala aäfit esa ona-ia. Hai mendi hau esa fò hò ka neu hau-a kalada-na fò hai luanggai mitembèle mò hò, hai esa na bido neu hau na tònggo-n seli, tè hai helu memạ hò afị mutumbò bafa-ma helu hau-a!» Bòe-ma nggua-a naselu ma nae: "malòle, hei lua-nggei mae ona-bè, au ae ona-ná bòe.» Bòe-ma mbui kaduạ-elu na-la lendi hau eëkụ nea dè nggua-a ka neu kalada-na. Dè mbui nggasa lua-n-isi latambèle lendi nggua-a, esa na nesị hau-a tònggo-n seli. Ala latambèle losa hataholi nggòlo-n bòe ma hataholi manasia nggòlọ na ino-lita-s dè ala landu, laäpapạ, hahamba saka-n-ala ma totòö lima-n-ala hu linda-lita nggua natambèle nesi kaladạ ma mbuị lua esa natambèle nesị nggua-a boboaona-na ma esa nesị boboa di-na dè ala dodò-doạ ${ }^{2}$ hu faị na dei dè lita manadadit na. Neu faị na nggua-a namanène hataholi na-la landu laäpapạ bòe-ma natane ma nae: "hu sa dè hataholi na-la eki landu na?» Bòe-ma bafa-na natambò hela hau-a dè ana tuda tena lae dè mate. Duduit na li-na ona-ná.

1 Lò ë (= Term. lòke)-latá, vgl. II in het dialect van Ringgou.

2 Dodó-doa $=$ Term. nakandá-doak, zich verwonderen. 
III.

Dudui[t] mbui anum-a nò è-oè-a.

Duduit ia, fèë ${ }^{1}$ lèle dala-ulu-na dano esa malòle hihiẹ. Ma sia dano na mbuị lua, nala-n anum, lèo sia hau talatai. Ma mbui lua-n-isi latalaị lò è-òe esa. Ma dò ena nò dedeat-a onaná bòe ma fandu-na nea dè dano na òe-na meti. Ma mbui, lua-n-isi lafade sila lai è-oè-na: "lai-é, hita tao tao ona-bè fò feä-n ia dano-a òe-na meti ena. Malòle hita lali teu dano feụ esa, fò hela hita sangga nanát sia na. Tè susa esa sia hai lala-ma sangga lao hela ho! Hu na dè malòle hai mò hò fò hai mboï hò mu mamana maòẹ esa, fò hela hai lala-ma loạ. $\mathrm{Ma}$ tè hai mae mitimbèle mò hò tè ngga bòle, fò hò lou-ma manggatè-hiẹ, hai ngga bòle iï-e. Kalu ona-ná na hai dedea-m esa sia ia: mendi hau esa nema ${ }^{1}$, fò hò iï neu hau na kaladana ma hai esa na natambèle tungga tònggo-n esa, tè hu afị huä bafa-ma sia hau-a!» Bòe-ma è-dano-a naäheị: "malòle, hei mae ona-bè na au tungga.» Bòe-ma mbuị na-la lendi hau eëkụ esa dè è-òe-a iï nala-n. Bòe-ma mbui anum na-la latambèle lendi-e, esa na sia tònggo-n esa. Lèle na mbuị na-la latambèle losa hataholi nggòlo-n bòe-ma basa hataholi-la toä ino-lita manadadit na: è-òe-a natambèle nesị kaladạ ma mbuị lua sia di ona-n. Bòe-ma basa-basa hataholi-la landu ma ala totòö lima-n-ala. Bòe-ma lèlẹ è-òe-a namanène hataholi-la lameli bòe ma natane: "basa-basa hataholi na-la lameli sa?» Ma lèlẹ na eni huä bafa-na bòe ma eni tuda lae nea de mate. Duduit ia ana tao ona-ná.

$$
\begin{aligned}
\text { Lafo-aẹ, } & \text { (-ume)-a nò lafo-fuị, (lasi-lalạ)-a, } \\
& \text { (vertaald door H. Taka). }
\end{aligned}
$$

Faị esa lafo-aẹ esa nahao lai-n lafo-fuị esa dè ana òfe nala basa naná malada ndè-ndè-n dè ana mbedạ-isi leu mamana manggamoị ata sia hataholi ume-n lala. Boè-ma lua-n-isi hòöhòö-hiẹ. Tè lua-n-isi feä lâ bòe ma tenu-umẹ-a neu; boè-ma lua-n-isi nggefu leu lendi mamate-n-ala nggodi lafo-aẹ-a kòlo-n lala leu. Dè tenu-umẹ-a feä fali deạ neu bòe ma lafo-ae-a nae: "uma fò deạ teu tâ hendi, (tabasa) ikọ-ala dei!» Bòe-ma lafo-

1 Fè in plaats van feä, (vgl. beneden feä-n ia), en nema in plaats van nea, behoort meer tot het dialect van Òenale. 
fuị-a nae:, lai-é!, malòle au fali lasi lala u-hau. Tèbe sia na na au ua deülalaka ${ }^{1}$ dè fulufafangga tè hataholi ngga mbu-denu dò laätataụ au-s, (au a-fa).

Lafo-aẹ-a nò lafo-fuị-a, (vertaald door T. Nalle).

Neu faị esa lafo-aẹ esa nahao tia-lai-na lafo-fuị esa, dè lafoae-a haï basa-basa naná malada-malada-la mia mamana-na nea dè tao neu mamana meụ hie-hie sia hataholi-la ume-na kalada-na. Dè hataholi manamatia-laị-elu na-la lua-n-isi lamahòö lala seli, tè sila lâ linu lala kaladạ bòe ma tenu-umẹ-a nea, bòe ma lafo kaduạ ${ }^{2}$-elu na-la lelạ lendi basa-basa nggafa-n-ala lesị lafo-aẹ na mamana fofòfo-na lalạ leu. Tèmbo tenu-umẹ-a deạ neu bòe ma lafo-ae-a nafada tia-lai-na nae: "uma fo teu tâ tabasạ hita naná manahela ${ }^{3}$-n-ala!» Bòe-ma lafo-fuị-a natá nae: hela ma na, ${ }^{4}$ lai, tè au sangga fali esị mamana-ngga u sia lasi-a kalada-na; tèbe sia na au naná-ngga deülalaka, aka-a hau-lò ma hau-okạ, tè hataholi ngga nea nuse ma naätatạ̣ au a-fa.

\section{Dialect van Òenale.}

\section{II}

Dudui mbui nggasa nò è-dano, (manadui nasabali tungga oölạ do hare-lí hatahori Òenale ma Dela nade A. Thei).

Sa fai maähulu-na dano esa manaä-na seli, sa dano na mbuị rua nara nggasa lèo sa hau tale-ra hu-n. Mbuị sira rua-s tao odi-aä rò è-dano esa. Faị baü-bè sira lèo sa na. Bòe-ma òe-dano na meti, hu hana-ine nema. Dè mbuị sira-ra rafade sira odi-aä è-na: "bó odi-aä feä-n ia au tao tao bè hu òe dano na meti ena. Malòle au lali u selụ dano maòẹ, fo au u sangga nanát sia na. Tè au toä sa au rala-ngga nda hi lao hela lamatuạ ia.

1 Deillalaka, fulu-fafangga, verbale vormen met reduplicatie (ook in causatieven zin) van deülaka en fulufang ga .

${ }^{2} \mathrm{Kadua}$, evenals boven sub II, zou nevens kalua in gebruik zijn, en zelfs als de beste vorm beschouwd worden. In elk geval is de vorm overgenomen uit een der andere dialecten.

3 Manahela, bedoeld is nenehelạ=Term. nanaelak, overgelaten.

${ }^{4}$ Hela ma na, vgl. Term. ela nème na. Ma is een verkorting van mia $=$ Term. nème. 
Hu na dè au ò lamatuạ-a fò mboï neu mamana maòẹ, fò ate-ma rala-na loạ, tè hu ate-ma nda nabeï natambèle nò lamatuạ-a, hu lamatuạ-a rou-na manggate-na seli, dè ate-ma nda seu nala-n. Bulụ-ma ona-ná oölạ esa ia, ate-ma nendi hau esa nema, fò lamatuạ-a iï neu hau na talada-na ma ate-ma seu neu hau na tònggo-na fò natambèle, tè afị huä bafa-ma mboï hau na!» Bòe-ma è-a naäheị: "malòle lamatuạ-ara rae ona-bè na ate-ma tungga”. Bòe-ma mbuị sira-ra rendi hau nggenggèrọ esa, bòe-ma è-a iï neu hau na talada-na ma mbuị sirara esa seu neu hau na tònggo-n seli ma esa neu tònggo-n seli. Dè ratambèle reu losa nggòrọ hatahori lelèo-n. Bòe-ma basa hatahori-nggòro na-ra seü-rita è-a natambèle nesị taladạ ma mbuị sira-ra esa nesị di ma esa nesị ona. Basa hatahori na-ra randu ma totòö lima-n-ara. Boè-ma è-a rena hara-lí manarandụ dò masanggatị-eru na-ra dè nafade nae: "basa hatahori na-ra randu sa?» Fèë huä bafa-na bòe ma tuda rae nema dè mate. Duduit na li-na ona-ná.

\section{III.}

Dudui mbui anum nò è-dano.

Fai ulu-n sia dano esa ralạ mbuị rua, nara anum lèo sia hau esa ata. Mbui karuạ-ara latia-laị rò è-dano esa. Ona-øna-ná fạ̣ esa bòe ma fandu lòe ndè mada dano-a. Bòe-ma mbui karuạ-ara rafade sira tia-lai-n è-dano-a, rae: «bó, lai-ngg-é, hita tao tao ona-bè, fò dano-a meti òe-n ena. Malòle hita huä teu selụ dano esa, fò hita sangga nanát sa na. Tè hai rala-ma haradoi nda hi lao hela-nggò. Ona-ná malòle hai mendi-nggò fò mboï-nggò sa dano maòẹ esa ralạ, fo hela hai rala-ma namaloa. Tè hai mae mendi-nggò nda bòle-s fò ho rou-ma manggate-na nasala, ndè hai nda bòle iï mendi-nggò. Ona ná na hai mifade-nggò fò hò mendi hau eëkụ esa, fò hò iï neu hau-a talada-n, ma hai rua-nggai mitimbèle mendi-nggò, esa na neu hau-a mbeda-n seri. Tè sadi hò afị huä hò bafa-ma!» Bòe-ma è-dano-a natá: "malòle hei mae ona-bè na au tungga ona-ná». Mbui karuạ-ara haï rala hau eëkụ esa, dè fè neu è-dano-a iï. Bòe-ma mbui anum-ara latambèle rendi-n, esa neu hau-a mbeda-n seri. Lèlẹ na ara latambèle losa nggòrọ esa bòe ma hatahori-ra rita dè ara heran tao ona-bè dè è-dano esa natambèle nesị taladạ ma mbuị rua esa natambèle nesị di ma 
esa nesị ona. Dè hatahori-ra rasanggati ma ara totòö lima-n-ara. Bòe-ma è-dano-a namanène harạ na dè natane: «basa-basa hatahori sira rasanggati sa?» Lèlẹ na ana huä hendi bafa-na bòe ma ana tuda rae nema dè mate. Duduit na sa ia.

IV.

Dudui[t] mbui anum nò nggua-dano.

Duduit ia, sia fai dalahulu-na dano esa malòle-hiẹ. Ma sia dano na mbuị rua, nara-n anum, lèo sia hau taratai. Ma mbui karuạ sira-ra ratiạ rò nggua-dano esa. Ma sia fạ̣ baü-bè rala-n rò manadadit na, bòe-ma fandu-na nema, dè dano na òe-na meti ena. Bòe-ma mbuị karuạ na-ra fade-fade rò sira tia ngguadano-n na: "tia-ngg-ò ${ }^{1}$-né, sa dadi hita fali, tungga neu dano-a òe-na meti ena. Malòle hita lali lèo dano feạ esa teu, fò hela hita sangga nanát-ara sia na. Tè sosonat esa sia hai rala-ma sangga lao hela-nggò. Hu na dè malòle hai mò-nggò fò hai mboï-nggò mu mamana maòẹ esa, fò hela hai rala-ma loa-loa. Ma tè hai sangga mitimbèle mò-nggò tè nda bòle, tungga neu hò rou-ma manggate-hiẹ, hai nda bòle iï-n. Kalu ona-ná na hai dedea-m esa ona-ia: mendi hau esa nema, fò hò iï neu hau na talara-na ma hai esa na natambèle tungga tònggo-n esa, tè hò afị huä bafa-ma sia hau-a!» Bòè-ma nggua-dano-a natá: "malòle, hei mae ona-bè na ou tungga.» Boè-ma mbuị na-ra rendi hau eëkụ esa, dè nggua-dano-a iï nala-n. Bòe-ma-mbui anum na-ra ratambèle rendi-n, esa na nesị tònggo-n esa. Lèlẹ fò mbuị-ara ratambèle losa hatahori nggòro-n, bòe-ma basa hatahori-ra ara mumúr reu rita manadadit na nggua-dano-a natambèle sia taladạ ma mbuị rua resị di ona-n. Bòe-ma basa hatahori-ra randu ma ara totòö lima-n-ara. Bòe-ma fạ̣ na nggua-dano-a namanène hara maäsòẹ-ara, bòe-ma natane: "basa hatahori na-ra randu sa?» Lèlẹ fò ana huä bafa-na, bòe-ma ana tuda rae nema de mate. Duduit ia ana tao ona-ná.

\section{Nako telu.}

Faị esa toụ rua ramanako rendi amba esa, dè toụ esa nasú nendi amba-a nesị eni ume-na neu, ma esak-a nau fò nasèo-e ${ }^{2}$.

1 $\partial$ voor hò wegens de voorafgaande $\mathrm{ng}$.

$2 E$ als object-vorm van den derden pers. enkelv., in overeenstemming met het Timoreesch, is blijkbaar in de dialecten van Dengga en Òenale de 
Bòe-ma rua ${ }^{1}$-s-eru rafetu dè rahemba ao. Dè mboï hendi amba-a nesị dala-ine-a neu de tou-nakọ esa neu dè ana mbò nendi-n.

$$
\text { Toụ rua rò titiạ-a. }
$$

Toụ rua lao-lao taï ${ }^{2}$ tasi-sứ-a bòe ma ara rita titiạ-a, re-a nendi-n namo-a nema. Dè toụ karuạ na-ra esa nae mesạ-ne na titiạ na, hu esa na nae eni nita naähulụ ana. Bòe-ma ara rafetu losa tou pòkẹ esa nema, dè ara denu-n naëtu rua-s-e nafetu-na. Bòe-ma tou pòkẹ-a nâ titiạ-a isi-na tè titiạ-a rou-na eni bingga-n neu rua, dè seri eni fè-n neu tou mafetụ na-ra esa ma seri neu esak-a.

\section{OORSPRONKELIJKE VERHALEN, ENZ.}

\section{Dialect van Baä.}

Touk esa neu dala, dè faik ndia ana ta nala hata esa bòe, nala kada iäk esa dè neni-n dè nakaboi-n neu ule òe esa dalek. Faik esa dè touk-a lèo tasi neu, dè ana fali bòe tè ${ }^{3}$ nita nanaänininuk-ala nanasadiak nai mei lain sò dè namanau-k-ana. Basa-

eigenlijke vorm. De daarnevens voorkomende $-\boldsymbol{n}$, (behalve mogelijk na een woord als fè, geven, waar het eene verkorting van fè-nè kan zijn), is wel met andere dialecten ingedrongen. Of nu werkelijk de laatste vorm den eerste bijkans zoo geheel verdrongen heeft als in deze vertalingen en verhalen, dan wel of het veelvuldige gebruik van $-\boldsymbol{n}$ aan de schrijvers (of vertalers) is te wijten, kan ik niet beslissen.

1 In het oorspronkelijke, waar, in afwijking van wat gewoonlijk geschiedt, de ingeslokte medeklinker aan het slot alsmede de door een hiaat in de uitspraak gescheiden vocalen door eene $q$ nauwkeurig zijn aangegeven, staat ruqa-s-eru, eveneens in het volgende ruqa-s-e, doch bijv. tonq rua. Volgens op Koepang verkregen inlichtingen zou men moeten schrijven: rua-se, (-s-eru); de bijzondere uitspraak schijnt mij ook vreemd toe, en zou ik niet kunnen verklaren, wat evenwel de mogelijkheid, dat de aanduiding juist is, niet uitsluit. Alleen een onderzoek ter plaatse kan hier zekerheid geven.

2 Tä̈=Term. Tä̈-taï of tai-tai.

3 In het Term. meer gewoon: bò e ma of tè alleen. Duidelijk blijkt overigens uit deze constructie, dat bòe oorspronkelijk alleen bij den voorzin behoort. 
basa faik-ala, maku-ma ana fali nème tasi mai tè nanaä-nininuk-ala nanasadiak memak nai mei lain sò. Neu faik esa bòe ma ana sangga kekedik fò ela nalelak sè-a ndia manatao nanaä-nininuk sila. Dè ana pèko nae lèo tasi neu tè ana kèke neu ai esa hu-na natitiak nò uma-na, dè mète nahèlek ule òe-a. Ta dòk-a bòe ma iäk-a nasafali dadi ana-fèö-ana manaä esa, dè seku dapu dalek neu dòde nasu. Bòe-ma touk-a nggitik neu dè haï nala lou-na dè nafuni-n, basa bòe ma ana laö seluk. Dè ana-fèök-a lali basa nanaä nininuk-ala leu mei lain, bòe-ma neu sangga lou-na fò ana sangga dadi iäk seluk. Neu tè lou-na ta-k-ana, bòe-ma 'ana ki lu mpinu. Dè ana bei ki-ki bòe ma touk-a dudi neu hampu nala-n. Ta dòk-a ana tao ana-fèö-anak-a dadi sao-na.

Een man ging uit om met een net te visschen, en dien dag ving hij niets, behalve één vischje, en hij nam het mede en verzorgde het in een pot, waarin men water bewaart. Op een dag ging de man naar zee en toen hij terugkeerde zag hij dat spijs en drank op de tafel gereed stonden en hij was zeer verbaasd. Alle dagen, als hij van de zee terugkwam, waren spijs en drank al vooraf op tafel gereed gezet. Op een dag zocht hij een listig middel om te weten te komen wie het was, die de spijzen en dranken gereed maakte. Hij deed alsof hij naar zee ging, maar hij verborg zich in een boom dicht bij het huis en hield den pot stijf in het oog. Niet lang daarna veranderde de visch zich in een mooi meisje en dat ging regelrecht naar de kookplaats ${ }^{1}$ om te koken. Toen sloop de man stil nader en nam hare (visch-)huid weg en verborg die; daarna ging hij weder heen. Nadat het meisje al de gerechten op tafel opgedragen had, ging zij haar (visch-)huid zoeken om wederom een visch te worden. Maar die huid was er niet, en zij begon bitter te weenen. Terwijl zij zoo weende, kwam de man het huis binnen en vond haar. Niet lang daarna werd het meisje zijne vrouw.

(Vertaald door O. Nalley. Vgl. No. 13 en 14 der teksten).

$1 \mathrm{Dapu}$ is aan het Mal. ontleend; hetzelfde woord in werkelijk Rottineesche gedaante: la ö, beteekent: de stookplaats, treeft. Aangezien in een gewoon Rott. huis geen keuken (u ma dodòdek of uma dòde-nasuk) aanwezig is, is de eigenlijke Rott. uitdrukking in plaats van dapu dalek neu dòdonasu: uma-dalek (of uma-tène-dalek) neu dòde-nasu. 


\section{Dialect van $\mathbf{T i}$.}

Tou nggoak telu.

Fai bakahulu touk esa ana bei ta nita hatahori saë ofak. Laï esa bòe nai ndia dale-n: "neuk-ò saë ofak na lòle-lèo saë ndara bòe.» Dè laï esa ana tao ofa-anak esa, tao basa ofak na bòe, ma rakonda-n neni tasi dale neu, dè ndia nò nonò-n dua dè sira telu ${ }^{1}$ saë ofak na. Dè tenu-ofak tao rapa esa neu ofak na langga-n dà ana leä-k-ana ma nonò-n manai ofak iko-n na toü fifiuk esa dè ana femba-n neu ofak na, tè bòso mae ofak na lalik ana ta ikiundak bòe. Dè tenu-ofak na nae: "au doak, ndara nenefado-beuk au bei saë ala lalaö-n bòe; tao lèo-bè dè au ta ala ofak ia lalaö-n ?» Bòe-ma ana iminasa dè ana haï ai keketuk esa, femba-n neu ofak na, dè ofak ikilulutuk, bòe-ma sira telu ${ }^{1}$ esak-ò fali uma-n neu.

Drie dwazen, (verhaald door J. H. Ohello).

In vroegeren tijd was er eens een man, die nog nooit gezien had, hoe men in een vaartuig voer. Op een keer bedacht hij: "zeker vaart (sai) men evenals men paard rijdt (s a ë)». Op een keer maakte hij een klein vaartuig; nadat het klaar was, bracht hij het in zee; toen nam hij twee makkers mede en gingen zij met hun drieën in het vaartuig. En de eigenaar deed een teugel aan de voorsteven en trok daaraan en (een van) zijne makkers in de achtersteven hield eene zweep in de hand en sloeg daarmede op het vaartuig; maar, laat staan dat het voortging, er kwam zelfs geen beweging in. En de eigenaar sprak: ik sta versteld; van een nog ongetemd ${ }^{2}$ paard, heb ik den gang, als ik het berijd, in mijne macht, hoe komt het dan, dat ik den gang van dit vaartuig niet in mijne macht heb?» En hij werd boos en nam een stuk hout en sloeg daarmede op het vaartuig en dit werd verbrijzeld en ieder van hen ging naar huis.

\section{Lafo nò danda.}

Tenu-tutuik-a ifada. Laï esa bòe ma lafo esa nò tia-lai-na

1 In het Term. zou dit moeten luiden sila telu-s; of het ontbreken van s, als a ra niet volgt, regelmatig in het dialect van Ti voorkomt, is mij onbekend; ook in het Term. wordt wel eens gezegd sila telu, enz, hoewel dit door anderen sterk afgekeurd wordt.

' Fado, beteekent: een paard zoo te binden, dat het den kop in de hoogte moet houden, als eerste bewerking om een wild paard te temmen; ne nefado (=nanafado)-beuk wordt dus eigenlijk gezegd van een paard, dat pas op die wijze behandeld is. 
danda esa ara saë ofak fò reu dolu. Mète-ma danda na dolu nala iäk esa na lafo na naä heni-n tè danda ${ }^{1}$ ta nita.

Ana dolu losa siluk mai bòe ma ala pale uli dè ara sèfe rasare tasi tataik. Bòe-ma danda suri ma iäk ta nai ofak dale ta kisek bòe-n, lafo naä heni basa-s ara.

Bòe-ma danda iminasa dè ana tabu neu ofak tatai-n bòe ma ofak mòlo. Hata dadi neu faik na? Danda lambu ela lafo nane sudi bebeï-na, baü-anak-a mate-n hu ana ta nane ilelak, Manalek kea esa nai fak-ara na. Dè kea dale-na mata-nonoi lafo-a dè ana fali nala lafo na. Lafo saë inggitúk neu kea rerèdo-n lain nò dale namahòkok, dè kea nane neni lafo lèo dae-inak neu. Te hu lafo na dale manggarau-na bei ta tuü heni-s ${ }^{2}$ ana, ana bei ta fale dale-na, ana ta inggitúk mamatu tè ana èdo fanggi kea langga-na, dè naä heni kea ute-na.

Tèbe lèo-ná lafo na idale-manggarau tè kea ta mbeda dalenasak hu lafo na tatao-na. Ara losa tasi-tataik bòe ma lafo parboku madak lain neu; ana tabu ei-na nai madak bòe ma ana kokolak nò kea nae: "mai tia-lai, nò-ra sira fak-a, mai teu fò au seu fè ò boak esa dò dua, fò minu òe-na ma muä isi-na.» Kea natá: "malòle, tia-lai!» Bòe-ma dua-s-ara laö rasare nòhú-ra, dè ara losa bòe ma lafo hène lèo nò lain neu seu nò-boak.

Tè lafo na dale-manggarau-na bei nahanik. Mète-ma ana seu nala nò-boak esa na ana naä isi-na ma ninu òe-na tè rou-na ana pesi-n numa lain mai dè laë kea rerèdo-na. Lafo tao lèo-ná laï telu dò ha bòe ma kea nameda ao-n hedis; bòe-ma ana nalai hèok ela nò na hu-na laö nasare tasi neu.

Ana losa tasi-tataik bòe ma nai na ana ineta nò mèo fuik esa par(a)boboku nai sarakaek, bòe-ma kea tui basa totoä-tatá-na nò lu mbinu neu mèo fuik na numa netehú-na losa makahito-na. Basa bòe ma mèo itane: "nisi-duak na nai bè?» Kea ifada: "manggarauk na nai nò na lain.» Bòe-ma mèo ifada: "mu lèon-a, tora-nò, dei, fò au u sangga lafo na.» Dè kea fali tasi dale neu ma mèo lèo nò na hu-na neu maku lafo. Dò-dò bòe-ma lafo konda numa nò lain mai dè mèo parboku kada laï esa dè ana

1 Het ontbreken van het enkelvoudige lidw. hier, en voorts meermalen, zou bepaaldelijk aan het dialect van Ti eigen zijn, wat juist kan wezen, dewijl de bewoners van dit landschap bekend staan, als bijzonder vlug te spreken; overigens is ook hier $a$ bekend als enkelv. lidw., evenals in het Term.

${ }^{2}$ Ta tu ü-heni-s ana, de $\mathrm{s}$ is gelijk Term. fa, evenals in het dialect van Dengka. 
kòbo nala-na, ana humu ta sala ndondou-na. Dè mèo-a naä heni lafo na, da-na baü-anak ta titi laë dae bòe na.

Tutuik ia nekesama-na lèo-ia:

Tèbe lèo-ná, mète-ma sè hada-na sama lèo lafo na, na ta heni hiek neu fai makahito-na ana hambu babala-na sama lèo lafo na bòe.

De rat en de reiger, (medegedeeld door A. Frans; vgl. $\mathrm{N}^{\circ}$. 6, ook 4 der Teksten, en het verhaal in het dialect van Ringgou).

De verteller spreekt. Op eene keer ging eens eene rat met haar vriend, een reiger, scheep om visch te vangen. Als de reiger er een gevangen had, at de rat dien op, zonder dat de reiger het bemerkte.

$\mathrm{Zij}$ vischten tot de dag aanbrak en toen wendden zij het roer en roeiden naar het strand. En de reiger zag dat er niet een enkele visch in het vaartuig was; de rat had ze alle opgegeten.

Toen werd de reiger boos en hij trapte tegen den zijkant van het vaartuig en dit zonk. Wat geschiedde er toen? De reiger vloog weg en liet de rat zwemmen zooveel zij kon en 't scheelde weinig of zij was omgekomen, omdat zij niet zwemmen kon. Gelukkig was daar eene schildpad in de nabijheid en deze had medelijden met de rat en kwam haar te hulp. De rat ging vol vreugde op den rug van de schildpad zitten en deze bracht haar aan land. Maar de rat had haar slechten aard nog niet afgelegd, zij had zich nog niet verbeterd, zij bleef niet rustig zitten, maar knaagde den kop van de schildpad door en at hare hersens op. Zoo slecht was de rat werkelijk, maar de schildpad koesterde geen wrok wegens de handelwijze van de rat. Toen zij de kust bereikten, sprong de rat op het droge. Toen zij den vasten grond betrad, zeide zij tot de schildpad: «kom, vriendin, hier zijn klappers in de nabijheid, laten wij daarheen gaan, dan zal ik voor u een of twee klappers plukken, opdat gij het vocht drinkt en het vleesch eet.» De schildpad antwoordde: "het is goed, vriendin!» Beiden gingen naar de klapperboomen; aldaar gekomen, klom de rat in een klapperboom om klappers te plukken.

Maar haar slechte aard bleef bestendig. Als zij eene noot geplukt had, at zij het vleesch en dronk het vocht, maar den dop wierp zij van uit de hoogte op den rug van de schildpad. 
Zoo deed zij drie of viermaal, en de schildpad voelde pijn en ging snel van den klapperboom weg naar den zeekant.

Aldaar gekomen, ontmoette zij eene wilde kat, die in het zand aan het springen was, en verhaalde onder tranen al hare wederwaardigheden van het begin tot het einde. Toen vroeg de kat: "waar is die "twee-tand» (rat)?» De schildpad zeide: "die slechte is daar boven in den klapperboom.» De kat sprak: "ga gij maar heen, vriendin, ik zal de rat opzoeken.» En de schildpad keerde naar zee terug en de kat ging naar den klapperboom om op de rat te loeren. Na eenigen tijd kwam de rat naar beneden uit den boom en de kat sprong slechts éénmaal en zij had de rat gevangen en greep haar zonder missen in den nek. En de kat verslond de rat, zelfs niet een weinig van haar bloed viel op de aarde.

De "gelijkstelling» (toepassing) van dit verhaal is het volgende:

Waarlijk is het zoo: als iemands wijze van handelen is als die van die rat, dan zal hij zeker later zijn loon krijgen, evenals die rat.

\section{Dialect van Korbaffo, (Kolobafo).}

Tutui nème hataholi manapèle pado esa.

Hataholi nggòlọ esa nonoï-tatao-na pèle pado. Nai faị esa bòe ma haï-ná pèle-n-ala dè lèo tasi neu hoï sanga pado. Losa èno taladạ bòe ma nita uma dua tao feta. Dè esa ndia bè na ala tao nanaä sò, tè esa ndia bè na bei ta tao fa. Bòe-ma ana afi nai dale-na nae: "malòle lenạ au ku mata sudi tasi-a mada sò dò beị.» Bòe-ma haï-ná pèle-n-ala dè lèo tasi-a neu. Dè losa bòe ma lelu tè tasi-a bei ta mada fa. Bòe-ma ana fali selụ lèo manasadia nanaäk-ala neu, dè ana losa tè ala fu lisa dedèdek-ala, hu feta-a basa-n sò. Bòe-ma ana haï-ná selụ pèle-n-ala bòe ma lèo uma feta fèèk-a neu dè hoï neu mata sudi laä-linu sò dò beị. Ana losa tè besak-a ala sadia nanaäk-ala. Bòe-ma ana afi nai dale-na nae: "malòle lenạ au ku mata sudi tasi-a mada sò dò beị.» Dè ana haï-ná selụ pèle-n-ala dè neu mata tasi-a mamada-na : "fò makaneni-ma bei ta mada fa na au fali lèo umo feta fèẹ ndia kuä kinu.» Dè ana losa tasi-a tè tasi-a mada basa dè lu sò. Bòe-ma touk-a sale-dale-na nasala dè ana tuü heni pèle-la dè 
ana fali selụ lèo uma feta ndia neu, dè losa tè hataholi esak-ò ta sò, hu feta basa-n sò, dè hataholi-la esa-esa-kò fali leo uma-na neu. Bòe-ma hataholi manapèle ndia fali lèo uma-na neu nò lima loụ.

\section{Verhaal omtrent iemand, die met fakkellicht inkt-visschen ging vangen, (medegedeeld door S. Ndoen).}

Iemand uit een dorp had tot beroep het met fakkellicht vangen van inktvisschen. Op een dag nam hij zijne fakkels en ging naar zee om inktvisschen te zoeken. Halverwege gekomen, zag hij twee huizen, waar men feest zou vieren. In het eene had men het eten al gereed gemaakt, in het andere nog niet. Toen dacht hij bij zichzelf: "het beste is, dat ik eens ga zien, of het al ebbe is.» Toen nam hij zijne fakkels en ging naar zee. Aldaar gekomen, bemerkte hij, dat het nog geen ebbe was. Toen keerde hij weder terug naar het huis, waar men het eten gereed gemaakt had ${ }^{1}$; toen hij daar kwam, had men de lampen reeds uitgeblazen, omdat het feest afgeloopen was. En hij nam wederom zijne fakkels en ging naar het andere huis, waar men feest zou vieren en wilde eens zien, of men al aan het eten en drinken was. Toen hij daar kwam, was men pas bezig de spijzen gereed te maken. Toen dacht hij bij zich zelf: «ik moest maar eens gaan zien, of het reeds ebbe is. " En hij nam wederom zijne fakkels en ging zien hoe het met de ebbe stond ${ }^{2}$ : "opdat ik, als het nog geen ebbe is, naar het andere huis, waar een feest gegeven wordt, terugkeere om te eten en te drinken.» Toen hij bij de zee kwam, was de ebbe reeds afgeloopen en was 't weer vloed geworden ${ }^{3}$. De man had daar erge spijt van, hij wierp de fakkels weg en keerde weer terug naar het huis, waar een feest zou gegeven worden. Aldaar was (evenwel) niemand meer, omdat het feest afgeloopen en iedereen naar huis gegaan was. En die visscher keerde met leege handen naar zijn huis terug.

\footnotetext{
1 Letterlijk: het huis, dat het eten gereed gemaakt had. In het Rott. wordt uma (huis), ook wel gebezigd voor de bewoners van het huis, gelijk trouwens ook wel bij ons, maar in andere uitdrukkingen.

${ }^{2}$ Letterlijk: hij wilde zien de droogte van de zee.

3 In het Term. zegt men steed̦s tasi-a lu mai (sò).
} 


\section{Dialect van Bilba, (Belubá).}

Tui sapi-a nò kapa-a.

Sapi esa natiạ nò kapa esa. Bòe-ma neu fạ̣ esa bana kaduạ sila leu lalakọ lai mò-nau esa fò lâ nau nai na. Bòe-ma neu faị lia makadèse-na seli, hu lia dè bana kaduạ sila ta labeki makadèse-na fa, dè duạ esa-esa-kò ${ }^{1}$ olu heni lou-na dè kona leu ladiu-òe lai lè esa. Kaiboị bòe ma uda bau-ina mai, hu lia dè sapi ma kapa lia bi lou-n-ala lakadòe. Dè sapi ma kapa lia kae lème lè lia dalẹ fò hai lou-n-ala, tè hu nò lai-laị naseli-n, dè sapi-a hai-ná kapa-a lou-na ma kapa-a hai-ná sapi-a lou-na. Dè kapa lia lou-na bau-ina ma sapi lia lou-na anak-a. Hu lia dè esa-esa-kò ${ }^{1}$ pake bòe ma sapi-a nameda kapa loụ lia laingòde nai ao-na ma kapa-a nameda sapi-a lou-n lia holu-holu nai ao-na. $\mathrm{Hu}$ lia dè losa besạ ia, mae sapi-a ao-na makapetạ naseli-n tè lou-na laingòde nai ao-na bòe. Tè kapa-a, mae ao-na palau, lou-na holu-holu nai ao-na.

\section{Er wordt verhaald van het rund en den buffel, (medegedeeld door A. Terik).}

Een rund was bevriend met een buffel. Op een dag gingen de twee dieren rond op een grasveld om aldaar te grazen. Dien dag was het zeer warm, derhalve konden de beide dieren het niet uithouden van de warmte, en ontdeed ieder zich van zijn huid en daalden zij af in een stroom om daar te baden. Plotseling kwam er een hevige regen, derhalve werden dat rund en die buffel bevreesd, dat hunne huiden nat zouden worden. $\mathrm{Zij}$ kwamen dus uit de rivier om hunne huiden te nemen, maar wegens de groote haast nam het rund het buffelvel, en de buffel het vel van het rund. De huid van den buffel nu was zeer groot, die van het rund klein. Derhalve, toen ieder van hen het vel aangetrokken had, voelde het rund de buffelhuid veel te ruim om zijn lichaam zitten, en de buffel voelde het vel van het rund veel te gespannen om zijn lichaam. Ten gevolge daarvan is het, dat tot heden toe, al is een rund nog

1 Het oorspronkelijke heeft tweemaal den onbegrijpelijken vorm esa-esa$\mathrm{ngò;} \mathrm{aan} \mathrm{mijn} \mathrm{zegslieden} \mathrm{was} \mathrm{alleen} \mathrm{esa-esa-kò,} \mathrm{(evenals} \mathrm{in} \mathrm{het} \mathrm{Term.)}$ bekend, welke vorm ook in de volgende verhalen meermalen voorkomt. 
zoo vet, zijn vel ruim om het lichaam zit. Maar al is een buffel mager, toch is zijn vel gespannen om het lijf.

Tou mamasukị dua lèo lai osi malòle esa dalẹ. Dè toụ sila duạ lèo nò nahụ́, esa na nae lia bei-bai-n-ala nu-n nème ulụ mai. Dè faị esa bòe ma dua-s-ala leni sila dedea-na lèo mane malelạ esa mata-n neu. Dè manẹ lia naketu dedeạ lia ma nae: "Kemi dua madadale ao, au hapu tea-na kemi dua bei-bai-mala osi bua-n». Tè lèo-lia-ò dua-s-ala ta lamanène fa. Bòe-ma manek-a tao lia malela-na dè dua-s-ala dadi bana. Dè bana sila duạ lanade tunga sila nade makaulu-na, esa nade kue mae esa nade kòde. Ma osi malòle lia nò isi-n dadi nula-nau.

Twee rijke mannen woonden in een mooien tuin. Beiden leefden in twist; ieder zeide, dat (deze tuin) van oudsher het eigendom van zijne voorouders geweest was. Op een dag brachten zij beiden hunne zaak voor een kundig vorst. En deze vorst besliste het geding en sprak: "gij beiden moet eensgezind zijn, ik heb het vaste bewijs, dat de tuin in gemeenschappelijk bezit was van uw beider voorouders. Maar desniettegenstaande wilden zij beiden daarnaar niet luisteren. Toen paste de vorst zijn (toover)kunde toe en beiden werden dieren. Die twee dieren nu kregen tot naam dien, welke overeenkwam met hunnen vroegeren (als mensch); het eene (dier) kreeg tot naam: moesang, het andere: aap. En de mooie tuin werd tot eene wildernis.

$$
\text { (Verbaald door N. Lona). }
$$

Tui ana dua dadi manafò kapa.

Faị esa bòe ma ana manafò kapa dua laneta lème ngòlọ esa, nade-na Kalin-late-n, anạ esa nade-na Bulan ma anạ esa nade-na Lun. Ana kaduạ ia-la lako-lako leu losa lène esa dalẹ. Bòe-ma dua-s-ala hahae ao-n, dè Bulan nafada Lun, nae-aa: "tola-nò-é, mai fò dua-ngita teu poi kapa-la leu lâ nau ma basa na fẹ̀ leu loli nai dano-ina-a dalẹ, fò dua-ngita teu lelu au lala-ng-ala lai mò èle». Bòe-ma dua-s-ala fè kapa-la lâ nau lakabète dè basa boè ma leu fè kapa-la loli lème dano-ina-a dalẹ dè dua-s-ala leu lelu lala-la lème mọ lia.

Lun nafada Bulan nae: "tolanò-é, kò lala-m-ala kaduạ ia-la manaä ${ }^{1}$-hihịí.

1 Een ontleend woord; ware het een echt Bilbasch woord, dan had het moeten luiden: maná. 
Bulan. Lèo-lia na tolanò sake esa, ma-aa au sake esa fò duangita teu tadiu-òe nai Oetanise.

Lun. Besạ ia dua-ngita teu lèon?

Bulan. Hó, dua-ngita teu lèon!

Bòe-ma dua-s-ala sake lala mane bekeesạ.

Lun. Mai dua-ngita foti takaneni lala kaduạ ia-la lai-na?

Bulan. Lèo-lia na kò malai makahulụ fò besak-a au tunga. Bòe-ma Lun fepa lala-na dè nalai ma Bulan-ò fepa lala-na dè nalai tunga dea; leu losa mamanạ esa nade-na Nò-kahạ́ bòe ma dua-s-ala bòke lala dè ala hahae.

Lun. Tolanò-é, Oetanise nai dòk-a dè lèon-a lèo èle teu, tè lala-la sota-lá-n seli.

Bulan. Basa, dua-ngita teu bea tadiu òe? Òe ia òe kalihokak-a, tè Oetanise dei fò òe-na manganeuk-a.

Lun. Òe Nò-kahák-a òe kalihokak-a-ò, malòle. Mai dua-ngita teu tadiu, tè lala-la sota sò-ò, kò bei nau lèo Oetanise teu!

Bulan. Òe kalihokak-a au ta kadiu fa, tè au malua bòe, basa-basa dahena bisuk-ala leu ladiu lai lia.

Lun. Tèbe-tèbe dahena bisuk-ala ladiu lai lia?

Bulan. Tèbe-tèbe, kò mae au pepèko?

Lun. Lèo-lia na dua-ngita bòso tadiu òe lia!

Bulan. Au kafada kò na, kela lala-la hahae-lá sò na duangita lèo Oetanise teu!

Lun. Lala-la hahae-lá sò dè mai teu lèon!

Bulan. Lapa lala-a, mai fò sake lèon!

Lun. Kò-ò bei ta lapa lala-ma bòe!

Bulan. Au lapa lala-nga dò bea.

Dua-s-ala lapa lai-lai dè saka, bòe-ma dua-s-ala fepa lala-n-ala dè leu losa Oetanise dè dua-s-ala bòke lala-la.

Lun. Kò masika paka lala-ma fò mai tadiu lèon, fò tadiu basa na besak-a fè lala-la linu òe.

Bulan. Hó, kela fò lala-la hahae-lá, besak-a fè linu òe.

Dua-s-ala leu òe-a su-na.

Bulan. Kò mita òe ia sò bòe dò beị?

Lun. Besa-besak-a au mai kita òe ia.

Bulan. Òe ia manganeuk-a dò ta?

Lun. Òe ia manganeụ hihị nonọ lilo-isik-a.

Bulan. Kò ita òe ia malòle? Ta hapu òe esa nai ita nusa-na lèo ia bòe.

Lun. Lia na tetèbek-ala.

Dl. 68 . 
Basa bòe ma dua-s-ala lufa heni pou lafa-n-ala dè lakahola dè ala palaboku lèo òe dale leu.

Lun. Amakè! Òe ia dema-na seli, tè mae demak-a-ò, makaneni kò tuku lalaụ esa neu dalẹ na au bòle sanga kala-n.

Bulan. $\mathrm{Hu}$ hata dè kò bòle sanga lalau lutụ esa nai òe ia dalẹ ma kò hapu?

Lun. Tolanò! Tolanò ta mita òe ia manganeuk-a fa?

Bulan. Lèo kò madiu nai òe Nò-kahák-a no kò bòle sanga hapu lalaụ esa? Au dodó kala kameda ta bòle fa.

Lun. Lia na tèbe lèo-lia.

Bulan. Kameda batu matua, (bau-ina) esa bòe-ò kò sanga doak-ana.

Lun. Bòso bòe dedea nalu-nalụ bali, madiu lai-lai, fò duangita teu lelu kapa-la dei, tè mahani kapa-la mòpo.

Bulan. Au kadiu basa sò, tè kò? Kò mae bei madiu na mahani nai ia, tè au lakọ lia ia sò, ita mai dòk-a sò dè au bi kapa-la mòpo, bulụ nako-la fò lenị.

Lun. Au bòe-ò bi; kò dei kapa sila kò kapa-m-ala, kapa au-fò sila, au papa-nga kapa-n-ala, dè makaneni-ma au kamòpọ ${ }^{1}$ na mahani papa-nga tati nisa au.

Dua-s-ala-lai-lai lakamadạ pou lafa-n-ala dè sake lala mane kaduạ sila leu losa kapa-la dae naná-na, tè lita kapa-la bei ta mòpo esa bòe.

Bulan. Ita dua nale-na, kapa-la basa-basạ bei lai ia, bei ta mòpo esa bòe.

Lun. Ita dua dadi tao lèo-bea, dè ita dua ta fò kapa-la fa ma dua-ngita teu takaminạ tasakẹ lala-ma teu tadiu òe!

Losa lèdo-a ana tenạ bòe ma dua-s-ala tada kapa-n-ala, esaesak-ò nò nu-n, hu dua-s-ala lakabubua kapa-n-ala, besak-a esa-kò fò nu-n dè lèo oka-kapa-a leu. Basa bòe ma fali lèo uman-ala leu. Dè ala ta tutui hata esa bòe, hu ala bi ina ama-nala, tolanò kaka fadi-n-ala.

Er wordt verhaald van twee knapen, welke buffelhoeders waren, (door J. M. Baleno).

Op een dag ontmoetten twee knapen ${ }^{2}$ die buffels hoedden, elkander op eene plaats genaamd Kalin-late-n, (het graf van

1 A u kamòpo = Term. au a mòpo-s, ook de $s$, als niet-nadrukkelijk voornw. v. d. $3^{\text {den }}$ pers. meerv., wordt in het Bilbasch tot den ingeslikten medeklinker, tenzij nog a la volgt, bijv. a u kamòpo-s-ala.

2 Ana, (denkelijk uit een ander dialect, bijv. uit dat van Ringgou) ook= Term. kanak, niï-ana, knaap, meisje. 
Karel), de een heette Boelan ${ }^{1}$, de andere Loen. ${ }^{1}$ Deze beide knapen trokken al verder voort tot zij op eene sawah kwamen. Toen rustten zij uit en Boelan zeide tot Loen: "makker laten wij beiden de buffels vrijlaten om te grazen en daarna hen zich laten wentelen in den grooten poel en laten wij beiden naar mijne paarden gaan zien, die ginds op het veld zijn». En beiden lieten de buffels grazen tot zij verzadigd waren, daarna lieten zij zich wentelen in den grooten poel, en zij beiden gingen zien naar de paarden, daar in het veld.

Loen zeide tot Boelan: Kameraad uwe paarden zijn zeer mooi.

Boelan. Bestijg gij er dus een van en ik zal het andere bestijgen en laten wij naar Oetanise gaan om te baden.

Loen. Zullen wij nu maar gaan?

Boelan. Ja, laten wij maar gaan!

En zij bestegen ieder een hengst.

Loen. Laten wij de paarden laten rennen om eens te zien hoe snel zij kunnen gaan!

Boelan. Draaft gij dan vooruit, dan zal ik volgen.

Toen sloeg Loen zijn paard en ging in draf voort en ook Boelan gaf zijn paard een slag en draafde achteraan; toen zij eene plaats bereikten, Nò-kahạ́ (de vier klapperboomen) geheeten, sprongen $\mathrm{zij}$ van het paard en rustten uit.

Loen. Makker, Oetanise is (nog) ver, laten wij daar dus maar niet heen gaan, want de paarden zijn zeer moede.

Boelan. Waar zullen wij dan gaan baden? Het water hier is troebel, maar dat te Oetanise is helder.

Loen. Al is het water te No-kahá troebel, het is toch goed, kom laten wij gaan baden, want, hoe kunt gij, ofschoon de paarden moe zijn, toch nog willen, dat wij naar Oetanise gaan?

Boelan. In dat troebele water baad ik niet, want ik ben er ook vies van, alle menschen met zweeren of wonden baden daar.

Loen. Is het waar, dat al die lieden daar baden?

Boelan. Het is stellig waar, denkt gij, dat ik lieg?

Loen. Laten wij dan in dit water niet gaan baden!

Boelan. Ik zeg u dus, laten wij, als wij de paarden hebben laten uitrusten, naar Oetanise gaan.

Loen. De paarden zijn al uitgerust, gaan wij dus op weg!

${ }^{1}$ Als eigennaam zijn de vormen Bulan (maan), Lun, Term. Ndun, (ster), bewaard gebleven, terwijl de woorden anders bula (Term. bulak), $\mathrm{lu}$, (Term. nd u k) luiden. 
Boelan. Toom het paard op en bestijg het maar!

Loen. Gij hebt toch ook uw paard nog niet opgetoomd!

Boelan. In hoeveel tijd zal ik het opgetoomd hebben? (= ik zal het dadelijk opgetoomd hebben).

Beiden doen snel den toom aan en stijgen te paard, zij slaan hunne paarden en gaan door tot zij Oetanise bereiken, dan springen zij van het paard.

Loen. Bind spoedig uw paard vast en laten wij gaan baden, daarna zullen wij de paarden laten drinken.

Boelan. Ja, laat de paarden eerst uitgerust zijn en dan drinken.

Beiden gaan naar den kant van het water.

Boelan. Hebt gij dit water al eens gezien?

Loen. $\mathrm{Nu}$ voor het eerst zie ik het.

Boelan. Is dit water niet helder?

Loen. Het is zeer helder als zuiver goud.

Boelan. Vindt gij het water mooi? Men treft geen ander water in ons land aan (zoo mooi) als dit.

Loen. Dat is waar.

Daarop trekken beiden hunne kleederen uit, en als zij naakt zijn, springen zij in het water.

Loen. Hè, wat is dit water diep, en hoewel het zoo diep is, kunt gij, als gij er eene naald ingooit, die (zoekende vinden) terugvinden.

Boelan. Waarom kunt gij als gij eene fijne naald in dit water zoekt, die vinden?

Loen. Makker! Ziet gij niet, dat dit water zoo helder is?

Boelan. Als gij in het water te Nò-kahạ baadt, kunt gij dan eene naald vinden? Ik denk, dat het wel niet mogelijk is.

Loen. Dat zal wel zoo zijn.

Boelan. Waarschijnlijk zult gij ook een grooten steen vergeefs zoeken.

Loen. Laat er nu geen lang gepraat meer zijn, baad snel en laten wij naar de buffels gaan zién, want zij zouden weg kunnen raken.

Boelan. Ik ben al klaar met baden, maar gij? Als gij nog wilt baden, blijf dan (maar) hier, maar ik ga nu heen, wij zijn al lang hier en ik ben bang, dat de buffels verloren gaan, misschien voeren dieven ze wel mede.

Loen. Ik ben er ook bang voor; wat u betreft, die buffels zijn uwe (eigen) buffels, de buffels, welke ik hoed, zijn van mijn 
vader, en als ik ze verloren liet gaan, zou hij mij dooden.

Beiden trekken snel hunne droge kleeren aan en bestijgen hunne hengsten, en toen zij den weide-grond van de buffels bereikt hadden, zagen zij, dat er niet één weg was.

Boelan. Wij hebben geluk, alle buffels zijn nog hier, er is nog niet één weg.

Loen. Hoe kon het ons overkomen, dat wij niet de buffels hoedden, maar ons vermaakten met onze paarden te bestijgen om te gaan baden!

Tot de zon onderging, hielden zij zich bezig met hunne buffels te scheiden, elk wat hem toebehoorde, omdat zij ze tot een troep verzameld hadden, (door elkander hadden laten gaan), toen dreef ieder zijne buffels naar de kraal. Daarna keerden zij naar hun huis terug. En zij vertelden niets, omdat zij bang waren voor hunne ouders en broeders of zusters.

\section{Lun sipo òe salani.}

Au sanga tui tou dintiu esa, nade-na Lun, anạ ia basaènek-a au besak-a tui kemi, ana manafò kapa bei lia ia. Kameda anạ ia namatua mai fa bòe ma ama-na fè fadi-na fò kapa-la, tè Lun bau ama-na sò bòe dè ama-na ta paleta-n ana sò, hu lia dè Lun tunga-tunga faị ana neu nakaneni tatao-na. Faị esa bòe ma Lun lako-lako nème lia ngòlo-na na lake fạ̣ lia tuan panita esa neu nème ngòló lia, dè tuan panita lia nita Lun bòe ma ana nalò nae: "ana-ng-ò, mai ia dei!» Bòe-ma Lun neu tuan panita mata-na dè tuan panita natane-n ana nae: "kò bau bau basa ia sò, tao lèo-bea dè kò ina-ama-m-ala ta nau salani kò bei dai ana-ma fa?»

Bòe-ma Lun nae: "tuan, au ina-ama-ng-ala dahena dintiu mesan, mae au tolanò-kaka-fadi-ng-ala lèo-lia, ma au kème ana-nga mai au lèo nai nula-nau dale fò au ama-nga kapa-na, tè hu au kamatua bòe ma papa-nga fè fadi-nga fò kapa-la ngati au».

Tuan-a ana nae: "hu lia dè au kafafali nai ia tè au ta kita kò, besa-besạ ia au kita kò nonọ dahena bebeụ esa nème dae damedò mai, tè au sanga kafada kò dedeạ esa, kò nauk-a dò ta?»

Lun. Makaneni-ma tuan nae lèo-bea na au tunga.

Tuan. Au sanga kadiu-ngò òe salani, fò kela kò bòle malelạ Mane-tua-lain nanau-na ma kela kò hapu masodạ soa neu kò samane-ma losa dodò-na neu ». 
Bòe-ma Lun nae: "au hi lèo-lia bòe, tuan, au nau-nau mesan, tè tuan foi au nade bea?

Tuan. Au foi kò nade Lukas fa?

Lun. Au hi nadẹ lia bòe, tuan, tè au kamanène ana manasakola-la lae. Lukas lia, lèo ami dedea-ma na uni bisu. Hu lia de tuan foi selụ au nade-nga, tè ta sò na mahani au ta nau salani fa, au afi au tia-lai-ng-ala lakadudula au nade-nga uni au kanade "bisu».

Tuan. Sò na au foi kò nade Benjamin, tè ta na Timothius.

Lun. Au ta kanade Benjamin fa, hu au ta kalelạ sosoa-na fa, au hi kada kanade Timothius; tunga ami dedea-ma na lae "titino», fò makaneni-ma ladudula au lae "titino» na au kae: "tè kemi titino lèo au bòe?»

Tuan. Kò hi manade Timothius?

Lun. Hó, tuan.

Tuan. Balahá kò lèo mamasọ dale mu fò au salani kò fa?

Lun. Hó, tuan.

Balahá Lun nita dahena salani dodoụ leu masọ lai mamasọ dale, dè ana neu masọ bòe. Ta dòk-a bòe ma panita mai dè nanoli nafada basa dahena salani sila-la bòe ma tuan-a nalò Lun lèo mata mai dè salani-n ana nanade Timothius.

Nème fạ̣ lia mai bòe ma Timothius ta hahae neu masọ fò ana namanène dedeạ dubea nai mamasọ lia dalẹ na ana neu tui ina-ama-n-ala ma basa-basa tia-lai-n-ala, losa tuan panita mai selụ bòe ma nalò basa-basa ina-ama-n-ala dè ana hule tuan panita salani basa-basạ.

Loen ontvangt den doop, (door J. M. Baleno).

Ik wil verhalen van een heiden, genaamd Loen, dezelfde van wien ik $\mathrm{u}$ heden juist zoo even verhaald heb, toen hij als knaap de buffels hoedde. Toen hij wat grooter was, liet zijn vader zijn jongeren broeder de buffels hoeden en toen Loen zoo groot was als zijn vader, had deze niets meer over hem te zeggen, derhalve ging hij elken dag naar zijn (eigen) werk. Op een dag, dat Loen in zijn dorp op en neer liep, trof het, dat de leeraar, (zendeling, hulpprediker), daarheen was gegaan en toen deze Loen zag, riep hij hem en zeide: "mijn zoon, kom eens hier!» En Loen ging naar hem toe en hij zeide tot hem: "gij. zijt al zoo groot, hoe komt het, dat uwe ouders $u$ niet hebben willen laten doopen, toen gij nog een kind waart?» En 
Loen sprak: "mijnheer, mijne ouders zijn maar heidenen, ook mijne broeders en zusters zijn dat, en ik heb van mijn kindsheid af in de wildernis geleefd om de buffels van mijn vader te hoeden; maar omdat ik groot ben, laat mijn vader mijn jongeren broeder in plaats van mij de buffels hoeden.»

De heer zeide: "daarom is het, dat ik, die hier herhaaldelijk kom, maar u niet gezien heb, u nu voor het eerst zie, alsof gij iemand waart, die pas uit verre streken gekomen is; maar ik wil $\mathrm{u}$ iets zeggen, zijt gij daartoe genegen ${ }^{1}$ of niet?

Loen. Wat mijnheer zegt, zal ik volgen.

De heer. Ik wil u doopen, opdat gij God's wil kunt kennen en gij heil voor uwe ziel verkrijgt tot in eeuwigheid.

En Loen sprak: "ik heb daar wel zin in, mijnheer, ik ben (daartoe) geheel genegen, maar welken naam wilt gij mij geven ?»

De heer. Zal ik u Lukas noemen? ${ }^{2}$

Loen. Mij bevalt die naam wel, maar ik heb de schoolkinderen hooren zeggen, dat Lukas (uitgesproken: Loekas) in onze taal (beteekent) "wond» (nam. het Mal. woord loeka). Daarom moet mijnheer mij een anderen naam geven, want anders zal ik niet gedoopt willen worden, ik denk dat mijne makkers (mij met) mijn naam zouden bespotten en zeggen, dat ik "wond" heet.

De heer. Dan zal ik u Benjamin of Timotheus noemen, welken van die twee namen wilt gij hebben?

Loen. Ik moet niet Benjamin heeten, omdat ik er de beteekenis niet van begrijp; ik wil alleen Timotheus heeten; in onze taal zegt men "titino» (gluren, loeren), en als zij mij voor den gek houden en "titino» noemen, zal ik zeggen: kunt gij lieden gluren als ik?

De heer. Vindt gij (dus) goed om Timotheus te heeten?

Loen. Ja, mijnheer.

De heer. Komt gij dan morgen in de kerk, dat ik u doop? Loen. Ja, mijnheer.

Den volgenden dag zag Loen vele christenen naar de kerk gaan, en hij ging er ook heen. Spoedig kwam de leeraar en nadat hij al de christenen geleerd en toegesproken had, riep

${ }^{1} \mathrm{Kò} \mathrm{nauk-a} \mathrm{dò} \mathrm{ta} \mathrm{in} \mathrm{het} \mathrm{Term.} \mathrm{ò} \mathrm{nau}$ dò ta, het Bilbasch bezigt den nadrukswijzer $a$, (oorspronkelijk ka) ook meermalen, waar hij in het Term. niet meer gebruikelijk is, vgl. beneden kò $\mathrm{n}$ auk-a $\mathrm{na}$ (enz.), als gij wilt, dan, (enz.), nanalek-a = Term. nanale, het is gelukkig.

${ }^{2}$ In het Bilbasch heeft fa zoowel de functie van Term. fa als (gelijk hier) van Term. ha. 
hij Loen voor en doopte hem met den naam van Timotheus. Van dien dag af verzuimde Timotheus niet ter kerk te gaan, en als hij van allerlei daar hoorde, vertelde hij dat aan zijne ouders en makkers, met het gevolg dat, toen de leeraar weder kwam, hij zijne ouders riep om te komen en den leeraar verzocht hen allen te doopen.

\section{Dahena nako-dá.}

Fai makahulu-na tou nako dua leu lamanako lème nusa mamasukị esa; nusạ lia dahena-n-ala mamasuki-mamasukị mesan, nai uma-n-ala lapeda lilo ma henu ma lanú kapa, lala, bibi lòpo; memạ dahena nako lèo-lia ala mèste leu lamanako nai nusa lèo-silak-ala. Faị esa hatu-na tou nako kaduạ ia-la leu lakaminạ susulạ lème nusạ lia; dua-s-ala tao lèo-lia fo kela ala tao aäfị neu dahena-la bua-loa-n-ala, tè hu manò-umak-a ta nau fè dahena sila lakaminạ lai lia uma-n dale fa, tè lakaminạ kada lai uma-deạ. Nako kaduạ ia-la ala ta bòle lita bua-loạ nai uma lia dalẹ fa dè lia na ala tao aäfị neu tou manò-umak-a bibi-n-ala. Sanga dulu pila bòe ma ala hae lakaminạ, dahena tua-inạ sila fali lèo sila uma-na leu tè nako kaduạ sila leu soi oka-bafak-a, dè ala fò leni basa-basa bibi-la. Balahá manafò-bibi-a ana lèo okak-a neu nae poi bibi-la tè bibi esa ta okạ dale bòe. Bòe-ma ana manafò lai-lai neu nafada nae leodaek-a dahena-la fò leni basa-basa bibi-la sò. Tou manò-umak-a ana ngènge, nai dale-na nae: "memạ tou kaduạ sila fò leni au bibi-ng-ala sò, basa-basa ana-ng-ala lai bea malò-má basạ, mai teu tunga nako sila!» Basa-basa anak-ala mai, esa-esak-ò hopu tè-tafa-n dè leu sanga nako kaduạ sila. Neu fai katelu-na bòe ma ala hapu-lá nako sila lème leạ esa dalẹ, ala fò bibi-la lèo leạ lia dalẹ leu, dè lafuni bibi-la lai na. Bòe-ma manò-bibik-ala losa dè ala tao lange leu lima-n-ala ma fò leni falị bibi-la tè nako kaduak-ala lâ heni bibi mane kalalị telu, dè leni nako-la lèo manek-a nai na neu. Dè manek-a kè fè lahuta pula falị selụ bibi mane kalalị sila telụ lake telu ma bibi masodak-ala fè falị basa-basạ ma fè hada-hol(o)mata lopia dua hulu lima ma hutasalạ-ò lopia dua hulu lima, ma manek-a helu nae: "boso duangemi meu mamanako bali, makaneni-ma dua-ngemi bei masale au mata-nga ma ala kalạ́ kemi nako-ma na mahani au fua heni-ngemi lèo nusa dọ meu, au ta nau dahena nako-dá lèo nai au nusa-nga fa. 


\section{Dieven, (door J. M. Baleno).}

In vroegeren tijd gingen eens twee dieven in een rijk land stelen; daar waren de menschen altemaal rijk; in hunne huizen bewaarden zij goud en paarlen en zij bezaten buffels, paarden, schapen, varkens; het is natuurlijk, dat dieven in zulike landen moeten gaan stelen. Eens op een avond gingen deze beide dieven aldaar kaart-spelen, zij pleegden zoo te doen om acht te geven op de goederen der lieden. Maar de heer van het huis, (waarheen zij zich begeven hadden), wilde niet toestaan, dat zij binnenshuis bij hem speelden, maar zij moesten in het voorhuis spelen. De beide dieven konden dus niet zien, wat er in het huis was. Toen het bijna de tijd was, dat de hemel zich in het Oosten rood zou kleuren, hielden zij op met kaartspelen en de menigte, (die daarbij toegezien had), begaf zich naar huis; maar de twee dieven gingen heen en openden het hek van de kraal en dreven alle schapen weg. Den volgenden dag ging de (knaap), die de schapen hoedde, naar de kraal om ze daaruit te laten, maar er was niet een schaap meer in. En hij ging haastig melden, dat dien nacht alle schapen weggedreven waren. De heer des huizes ontstelde en dacht bij zich zelf: "stellig zijn het die twee mannen, die mijne schapen weggedreven hebben; roep al mijne knapen op, waar zij zich ook bevinden, laten wij die dieven achtervolgen!» $\mathrm{Zij}$ kwamen, ieder gewapend met lans en zwaard en gingen de beide dieven zoeken. Op den derden dag vonden zij ze in eene grot, waarin zij de schapen gedreven en verborgen badden. Toen de eigenaar der schapen er bij kwam, deed men hun boeien (lett. blokken) om de hand en dreef de schapen naar huis terug, maar de dieven hadden drie gesneden rammen opgegeten; toen voerden zij de dieven voor den vorst. En de vorst aldaar veroordeelde hen om de drie gesneden rammen drievoudig te vergoeden en de nog in leven zijnde schapen alle terug te geven en om te betalen als "eerbewijs» (boete voor den vorst) vijf en twintig gulden en evenzooveel als boete wegens het misdrijf, en de vorst waarschuwde hen en zeide: "gaat niet meer uit stelen, indien gij nog eens voor mij verschijnt en aangeklaagd wordt wegens diefstal, zal ik u naar een verafgelegen land verbannen; ik wil niet dat er een dief in mijn land woont. 
Dolu ikạ.

Nai nusạ ia dahena manadolu dodoụ. Makaneni-ma lae leu dolu ikạ na ala sake kofạ, leni tali-dolu, dolu-isị. Ala leu losa lai òe-a dema-na, lakalalạ́ lea telu hulu, na ala tuku naka fò ala nafu. Besak-a ala dodòko tali-dolu-a nò dolu-isik-a, ma na tè hanik-a ala tao-n nai dolu-isik-a peda-na, ala tuku-n leò tasi-òẹ dale neu fò kela hanik-a neu losa tasi-òek-a bui-n. Makaneni-ma ikạ ta leu la hanị lia fa na ala lali selụ mamanạ. Lèolèo-lia losa hapu ikạ. Ta hapu ikạ fa sò na mahani ana fali lèo dae-inạ mai nò loụ.

Tolanò-é, au-ò dolu kita sò bòe, tè au ta hapu hata esa bòe, losa basa au tua-lepa-ng-ala dè au kamalá, hata-hís-a mate au hu lak-a. Tè malòle ami losa dae-inạ lai-lai dè au bei kasoda losa faị ia. $\mathrm{Hu}$ lia dè mafalelène kemi mae meu dolu na kela kemi meni tua-lepa dai dei!

\section{Visch met den hengel vangen, (door J. M. Baleno).}

In dit land zijn vele hengelaars. Als zij visch met den hengel willen gaan vangen, gaan zij scheep en nemen mede een hengelsnoer en een hoek. Als zij in diep water komen, naar schatting dertig vadem diep, werpen zij het anker uit en blijven daar liggen. Dan vieren zij het vischsnoer met den hoek, terwijl zij het aas aan het uiteinde van den hoek bevestigd hebben. Zij werpen het aas (zoo) in zee, opdat het op den bodem kome. Als de visch niet wil aanbijten, veranderen zij van plaats. Zoo gaan zij voort tot $z \mathrm{ij}$ visch vangen. Vangen $z \mathrm{ij}$ geen visch, dan zullen zij met leege handen naar land terugkeeren.

Vriend, ook ik heb getracht te hengelen, maar heb niets gevangen; het kwam zoo ver, dat al mijn leeftocht op was en ik honger leed, het scheelde weinig of ik was van honger gestorven. Het was gelukkig, dat wij spoedig land bereikten, en ik dus nog tot op heden gezond en wel ben. Denkt er derhalve aan, als gij wilt gaan hengelen, om voldoende leeftocht mede te nemen!

Tui mane pòkẹ esa lèo nai nusa muli.

Nai nusa muli manẹ esa nade-na Kai-ou, manẹ ia ana bongi ana-buku-dua, esa nade-na Nalu-fai ma esa nade-na Loa-lèdo, 
tè hu manẹ ia namalasi sò, dè ana ta bubulụ ana-n bea dadi manẹ ngati lia. Manẹ ia bòe-bòe namalasi dè ana pòke ma ana pake, langa-dò-na fula ma nisi-na mosu, ta nita hata-hata sò ma ta namanène hata-hata sò. Mai faị esa bòe ma basa manesio-la lalake-na lakabua lème manek-a uma-n fò ala sanga afi tao lèo-bea, fò manek-a mata-na nakadila. Ta dòk-a bòe ma lasị esa nafada ma nae: "au kamanène lae, makaneni-ma manek-a namanène manu-puị esa nakamè sò na mahani manek-a mata-na nakadila». Manek-a namanène dedeạ lia bòe ma nae: "au poi paleta, makaneni-ma bea neni manu-puị lia, fò ana nakamè ma au mata-nga nakadila na mahani lia dadi manẹ ngati au ma au suki-ng-ala au fè basa-basạ leu lia lima-na». Manek-a ana-n duạ, esa nafada esa nae: "itu dua afi dei, tè dua-ngita ta teu sanga manu-puị lia fa na mahani ita dua esa ta dadi manẹ bòe, tè mae dahena hihị, ana sanga neni-n mai na mahani lia dadi manẹ fò ana paleta selụ ita dua. Lèo-lia mai teu sanga tè ita dua mane-anạ, bulụ Lamatuak-a sue ita esa fò ana hapu manu-puị lia, sadi manek-a tetèke-na bòso lèo dahena hihị lima-na neu».

Bòe-ma dua-s-ala lafada ina-ama-n-ala fò tao lepa fè dua-s-ala. Faik-a nalá ${ }^{1}$ bòe ma dua-s-ala sipo lala lepa, dọ̣ nò pou-lafa dè dua-s-ala lako-lako leu sanga manu-puị lia. Leu losa èno kasingọ esa bòe ma dua-s-ala òfe lepa dè lâ linu ma lateteka ao, esa deki esa, bòe-ma dua-s-ala lasida, Nalu-fai tunga ènokonạ ma Loa-lèdo tunga èno-kị. Nalu-fai lako-lako neu losa ngòlọ esa de neu hapu dahena-la liku mèko ma ala linu sopi ta hohokạ. Dè Nalu-fai ana asa nininụ dè nò basa-basa dahena-la linu mafụ. Lèo-lia losa basa lia doi-na ma nasèko heni basa pou-lafa-na.

Loa-lèdo ana tunga èno-kị dè neu losa ngòlọ esa ma ngòlọ lia bei namanène paleta nai mane-anạ lia ama-na. Mane-ana ia neu losa ngòlọ lia dalẹ bòe ma ana dudi lèo ina-falu esa umana neu. Mane-anak-a nae inak-a nae: "ina-ó, kò sue au fa dei, kò hi bòe na fè au òe fa fò au kinu dei, tè au ma-nga madak-a ». Ina-falu-a neu lui ${ }^{2}$ neni òe neu ngalạ́ ${ }^{3}$ esa dalẹ dè fè maneanạ lia ninu, tè hu ina-falu ia ta nalelạ anạ lia manek-a ana-n. Mane-anạ ia ana lelu lèo loạ lain neu tè toụ esa napeụ nai

1 Nalá =-Term. nandá.

2 Lui $=$ Term. ndui.

3 Ngalạ = Term. nggalás. 
lain. Toụ ia ta napeụ fa tè toụ ia mate dòk-a sò, tè hu ana nahuta dahena ngòlo lia doi-na nò bua-loa-na ta hohokạ, hu lia dé ala ta nau latoi-n ana fa. Ina-falu ia tui basa-basa sila leu mane-anak-a, bòe-ma mane-anak-a nadenu ina-falu-a nalò basa-basa dahena sila: "fò au sanga tifa tou manamatẹ ia hutana». Ina-falu-a nò ana-mạ́ sila lai-lai leu lalò dahena-dahena sila, dè mane-anak-a tifa-s-ala losa basa doik-ala, bòe-ma ana òfe bua-loa-n-ala fò sanga tifa neu. Tè dahena ia-la lelu lalelạ bua ia-la bua manẹ, sila mane-na bua-n-ala bòe ma nai dale-nala lae: «fa fò ita mane-na ana-n esa lia ia». Basa dahena sila bei lelu lalelạ mane-anạ ia bòe ma lafada mane-anak-a: "ami ta nau mane tifa ami sò, malòle lenạ ami-a meu matoi tou manamatẹ ia lèon!» Ngòlọ lia dahena-n-ala foa bela-bela, dè leu kali bòlọ ma tati kopạ dè leu latoi tou manamatẹ lia. Latoi basa bòe ma mane-anạ ia lako selụ lèo nusa beụ neu, fò sanga manu-puị lia. Mane-anak-a neu losa kai kạ esa hu-na dè ana hahae fò sanga nâ ${ }^{1}$ ka-boạ. Hahae ta dò bea bòe ma ana ketu nala ka-boa latụ sila dè ana nâ. Ana nâ basa boạ esa na ana hela hahae-na, lèo-lèo-lia losa lake sio. Manu-puị ta hohokạ leu lâ kạ lia boa-na, manu-pui ngeọ esa nai kạ lia poi-na, ana nita mane-anạ ia toka naseli-n, bòe-ma manu-pui ngèo ia natane nae: "mane-anak-a, kò toka dubea?» Boè-ma mane-anạ ia tui nème makasososa-na mai tao lèo-bea dè lia mai losa nai ia. Manu-puị ia nae: "kò bòso bi, tè mahani kò hapu manu-puị lia. Kò lakọ tunga nula ia dalẹ fò sai nai mọ èle na nai mọ èle mahani kò mita kota batu esa, nai kota lia dalẹ ina malidạ esa nakaboi manu-puị lia nai lia, tè au kafada kò, makanenima kò mu na mahani kò mita mènge pilạ dua lanea lai kotabafak-a. Kò mu mita mènge sila mata-n-ale lakadila na lako makalò, tè makaneni-ma mata-n-ale nanakenạ na bòso mu, tè mènge kaduạ sila lamedạ. Mènge kaduạ sila lanea lahèle ina malidạ lia na manu-puị lia. Makaneni-ma kò hapu inạ lia nò manu-puị lia meu losa kò nusa-ma fò kò dadi manẹ ngati ama-ma na kò masanenedạ au, fò kela kò suki-m-ala lalake-na mèste dua-ngita tabatị.»

Bòe-ma mane-anak-a natá nae: "malòle». Boè-ma mane-anạ

1 Ofschoon overigens de gerekte uitspraak van den klinker in eenlettergrepige woorden niet nader aangeduid wordt, wordt hier en in de overige dialecten, welke dezelfde samentrekking vertoonen, om verwarring te voorkomen, geschreven $\mathrm{n} \hat{\mathrm{a}}=$ Term. naä, hij eet, (zoo ook, ofschoon minder noodzakelijk, lâ, râ=laä, zij eten, tâ =taä, wij eten). 
ia sea-sea mesan nula-ina lia dè neu losa mòk-a bòe ma ana lelu nita kota esa dè ana lako nasale kota-bafak-a. Ana neu dè ana nita mènge kaduạ sila mata-n-ala lakadila dè nae: "mènge iala ta lamedạ fa, ala sungu lamanè». Dè ana sailòlo kota dale neu. Neu losa uma-a folotana-na bòe ma ina malidak-a hae-ná bò beụ nai uma-deạ. Lai-lai inạ ia sefi poi folotana-a papaka-na bòe ma ana nita Loa-lèdo. Loa-lèdo bei ngènge inạ ia lòle-na bòe ma ana lokopesi lèo dae-a neu losa ana sapalao. Lai-lai inạ ia kòko nala-n dè neni anạ ia léo uma-dalẹ neu, dè namòdo anạ ia losa mata-na manganeụ. Bòe-ma ina malidạ ia natane-n ana nae: "tao lèo-bea dè kò mai sai nai ia?» Bòe-ma ana tui nème makasososa-na mai lia tao lèo-bea dè lia sai nai ia. Inak-a namanène basa tutui-n sila bòe ma inak-a namahòko dè ngute anạ ia lima-fanga-na nò kedi langa-dò-na. Basa bòe ma fè-n ana pake bua malòle. Manu-pui manamakamẹ lia-ò nai lia bòe dè bei namanène dedeạ lia ana namahòko, fa na ana la lèo ina malidak-a neu, fa na ana la lèo mane-anak-a neu. Bòe-ma losa teụ telu tetu-tetu dè ala sanga fai malòle fò ala sanga lako. Faị esa inak-a ana lelu mènge kaduạ sila mata-n-ala lakadila bòe ma ana soi uma-a folotana-na dè ana kalua nò mane-anak-a ma nò manu-puik-a, dè telu-s-ala lalai. Leu losa èno taladạ bòe ma ina-malidạ naselụ leleli-na nò mane-anak-a. Telu-s-ala lako-lako leu losa èno kasingok-a fò mane-ana kaduạ sila hahae fò lâ-linu-a bòe ma Loa-lèdo nafada ina malidak-a nae: "au kò tolanò-nga ami dua-ngami masida mème mamanạ ia, tè ami mahelụ mae: "ami dua-ngami mèste esa nahani esa nai mamanạ ia». Ina malidak-a-ò tunga mane-anạ ia dedea-na dè ala lahani.

Ta dò bea bòe ma Nalu-fai mai nème ngòlo lia mai tè ta neni hata esa bòe, tè ana sanga aäfị fò nae nakamate fadi-na Loa-lèdo. Ana mai losa bòe ma nae: "au ma-nga madak-a, lako kela ina malidạ ia nò manu-puị ia lème ia, fò dua-ngita teu sanga òe fa dei fò tinu!» Loa-lèdo namahèle kaka-na Nalu-fai dè ala leu sanga òe fò linu. Tèbe leu hapu òe-mata esa, demana lea dua hulu lima. Nalu-fai tuti kai-lòngẹ dè ana paka balè neu kai-lòngek-a peda-na fè fadi-nạ neu dolu. Loa-lèdo bei dolu òe bòe ma Nalu-fai napadeị nème Loa-lèdo dea-na, dè ana soli Loa-lèdo lèo òe-mata dale neu, dè ana lako kela fadi-na nò mamate dale-na. Dè ana neu nò ina malidak-a ma nò manu-pui manamakamè lia lèo lia nusa-na neu. Leu losa mane Kai-ou-a uma-na bòe ma, Nalu-fai neu nafada ama-n nae: "au hapu 
manu-puị lia sò.» Tè hu manu-puị lia ta nau nakamè fò kela ama-na mata-na nakadila. Tunga-tunga fạ manu-puị ia namangoa$\mathrm{k}$-ana ma ina malidạ ia namananau-k-ana, hu lia dè inạ nò manu-puị ia lèo nai Loa-lèdo kama-na dalẹ ma basa faik-ala kama lia folotana-na nanakenạ.

Manu-puị fò manai kạ lia poi-na ana dadi neu tuan Olana esa dè napadeị neu òe-mata lia su-na dè ana dodòko kai-lòngẹ fè Loa-lèdo, tè Loa-lèdo nae: "fa fò kai-lòngẹ ia ketu-n fò au tuda bòe ma au mate." Tuan Olana ia nae: "ta, sadi hopu mahèle!» Loa-lèdo hopu nahèle kai-lòngẹ lia, dè tuan Olana lia hela Loa-lèdo lèo lain mai. Tuan ia helu Loa-lèdo nae: "mu lèo kò nusa-ma mu fò makaneni-ma kò hapu kò kakau pinga-ma sò na masanenedạ au dè bulụ ala soku kò dadi manẹ na basabasa suki-m-ala dua-ng-ita tabatị tetu-tetu.» Loa-lèdo natá nae: "malòle». Loa-lèdo bei ta leò lia uma-na neu fa, tè ana lèo lia nusa-na pasa-n dale neu dè ana sanga tataọ. Loa-lèdo ta namata mane-anạ sò, òe-a ène-ná-n ta malòle losa lou-na kukulu. Loalèdo neu pasạ dale dè nita lia ama-na ina manadòde-na dè nae: «ina-ó. au tunga-tunga kò dea-ma fò kela kò bòle madedenu au tao kò tatao-m lèo safe kulẹ dò dubea-dubea, sadi kò fè au kua kakabebète, mae kakau putụ bòe-ò neu.» Ina manadòde-a nae: "bòle, kò nauk-a sò na mai teu!" Loa-lèdo tunga ina manadòde-a dea-na, fò makaneni-ma Loa-lèdo tao nasala hatahata esa na inạ ia fepa-n. Lèo-lèo-lia tunga-tunga faị. Ina malidạ manai kama dale nalelạ nae Loa-lèdo fali sò, hu lia dè fai, lia ina malidak-a hulu ina manadòde-a kakau-òe. Bòe-ma ina manadòde-a fè Loa-lèdo safe kulẹ esa fò fè-n ana dòde kakauòe. Loa-lèdo tao nala bòe ma ina manadòde-a nadenu sòde neu pingạ esa, fò nasafali kakau-òe lia fò dadi makasufụ. Boè-ma Loa-lèdo olu heni leleli-a fò ina malidak-a fè-a, dè ana tao-n neu kakau-òe dale. Ina manadòde-a hai neni kakau-òe ia neu bòe ma ana fè-n lèo ina malidak-a. Inạ ia nasafali kakau-òe ia bòe ma nita leleli-a dè nae: "tèbe Loa-lèdo fali sò.» Mai hatuna bòe ma ina malidak-a soi uma-a dè kòko neni Loa-lèdo neu nadiu-n òe ma fè Loa-lèdo pake bua beụ. Balahá bòe ma ina manadòde-a lelu nita mane-aña ia bòe ma nalelak-ana de nae: mane-anak-ó, bòso mamanasa, nadò basa fai-la au paleta kò safe kulek-ala tè au ta bubulụ kae mane-anạ kò fa.» Mane-anak-a nae: "ta, au ta kamanasa.» Manu-pui manamakamèk-a tabataba nò namahòkọ bòe ma mane-anạ ia neu nafada ama-na nae: 
«au fali sò, kuni manu-pui makamẹ lia nai ia sò.» Bòe ama-na bei namanène manu-puị lia hala-òe-na bòe ma mata-na nakadila. Basa-basa lasi-lasik-ala mai dè ala soku Loa-lèdo ngati ama-na ma Nalu-fai, dahena mangalaụ, hu ana nae nisa fadi-na dè ala tuku heni-n ana neu òe-mata esa, dema-na lea telu hulu; makaneni-ma lia nu-na lọ ${ }^{1}$ lèo fadi-na, mahani lia nasoda, tè makaneni-ma lia nu-na salạ, mahani mate-n ana. Dè leu losa bòe ma ngali soli heni Nalu-fai lèo òe dale neu. Faị esa bòe ma tuan manafali Loa-lèdo nème òe-mata lia mai fò kela dua-sala labati nusa-nusak-ala ma basa-basa hata-hata lalake-na. Loalèdo nafalène heni- $n$, besak-a tuan Olana ia tui matalolòle-n ana besak-a Loa-lèdo nafalène, de dua-s ala labatị leu dua tetu-tetu. Basa sila ia ${ }^{2}$ sò, bei kela ina malidak-a bali. Bòe-ma Loa-lèdo lesu-ná tafa-na nae tati inak-a bati neu dua. Tuan Olana-a nae: «bòso, bòso, au mai ia soba kakaneni kò, sa kò sue au dò ta, au lelu tè kò sue au losa kò sanga tati inạ ia neu dua bòe de basa-basa hata-hata ia-la au fè kò.» Tuan-a bei nafada nae lèolia bòe ma mòpo-k-ana. Loa-lèdo nò ina malidak-a ala sao.

Loa-lèdo sao ina malidak-a dè ta dò bea bòe ma inak-a nailu, de ana bongi tou-anạ esa, dua-s-ala foi anạ ia nade-na TouLoa. Anạ ia namatua ta nau namanène ina-ama-na paleta-na, ana sudi lako lule nusak-ala. Mai fạ̣ esa bòe ma anạ ia fali nème dae dame-dò mai tè ina-ama-na mate sò ma ala soku mane beụ sò, dè ana ta bòle dadi manẹ ngati ama-na sò bòe. Mai fạ̣ esa ana nâ heni basa ina-ama-na hata-hata-na bòe ma neu nâ ngadi nème kofa-balụ esa lain. Tè ana helu manò-kofak-a nae: "makaneni-ma basa au fai-ng-ala, mae nai tasị lain tè mae nai dae-inạ, neu fạ̣ lia mèste poi au.» Neu fạ̣ lia fò sanga basa fai-n-ala tè sila kofa-na bonu-bonu nai tasi-ina lain. Basa lia fai-na bòe ma ana nakabubua basa dahena kofa-isị lalake-na dè ana nakaminạ nò-s-ala, ana nateka basa-basạ nae: "au mèste kona faị ia, hu makasososa-na au helu basa sò au kae: makaneni-ma basa au fai-ng-ala au mèste lako faị lia bòe. " Basa-basa kofa-isik-ala ma manò-kofak-a ala kokòe-n lae: "ita nai tasi taladạ dè bòso mu dei, ami ta fè-ngò tao hata esa bòe, kada mua minu, ma basa buluk-a ma kò sipo ngadi-ma katetema.» Mae lèo-lia bòe-ò Tou-loa ta nau fa, dè ana hai nala popoti-na

1 Lò $=$ Term. ndòs.

${ }^{2}$ Sila ia=Term. ndè ia. 
dè bòke lèo tasị dale neu, dè ana ane-ane mesan. Tè hu manòkofak-a sue selụ Tou-la dè ngapek-ana mai selụ. Tou-loa mai bòe ma ala fè-n ana kofa-anạ esa, fò kela mesa-mesa-k-ana sake. Boè-ma Tou-loa hapu kofa-anạ ia nò popoka hitu lai lain. Ta dò bea bòe ma Tou-Loa lako fèke ma kofa-inak-a lako fèke.

Tou-loa neu losa nusạ esa, tè hu nai nusạ lia ta hapu dahena lèo lai lia. Tou-loa neu losa oli esa bafa-na dè ana nafu kofak-a, bòe-ma lako kela kofak-a nò basa-basa popoka sila lème lia. Neu losa nusạ lia boboa-kí-na bòe ma lalana nita uma esa nanasini tula-dò, dè ana lako nasale uma lia. Uma lia nitu hitu uma-na, tè nanalek-a Tou-Loa neu tè nitu kahitụ sila ta-k-asa, leu lamanako nai nusa dame-dò. Tou-loa neu lèo uma lia dalẹ neu, ana nita ina-falu esa nai uma lia. Ina-falu-a nafada-n nae: "kò ua-ma, kanak-ó, nitu-la mai, mahani ala lâ-ngò kò ta dai meu nisi-oda-n-ala bòe.» Tè hu inạ ia kekedi dai lena, hu lia dè nitu-la fai fafali-na nalá boè ma ana neu kena anạ ia nème balaka tada kasiọ esa dale, dè ana ngòe nisa balaka lia. Nitu kahitụ sila fali bòe ma hae-lá bò beụ nai uma lia dalẹ, tè inạ ia namanino nae ta. Tè dahena ia, Tou-Loa, bò-na nasuka pana-bòlo-na seli, losa nitu-la busa manasopu-n-ala hae-lá bò-na lasú ka. Nitu kahitụ ia-la latane inak-a mahani-mahani dè losa inak-a natá nae: "lia na tèbe». Inak-a kokòe nitu kahitụ sila fò bòso lisa Tou-loa: "tè au kamalasi sò, makaneni-ma kemi hitu meu sanga naná-nininụ na bea dòde nasu kela kemi?» Nitu uluk-a: "dahena lia nai bea, mò-n ana lèo ia mai, fò au sanga kua-n ana!» Nitu mulik-a nae: "tola-nò, bòso tao lèo-lia, kò afi matalolòle dei, inạ ia namalasi sò.» Dò-dò bòe ma nitu kahitụ sila lae: "lia na tèbe». Inak-a neu huka balaka tada kasiok-a dè fè Tou-loa lèo deạ mai, fò kela nâ ninu bela-bela nò nitu sila. Fai-a nalá na nitu kahituk-ala leu lamanako losa faị hitu besak-a fali. Lake esa kela Tou-loa nò ina-falu lia lanea uma. Ma nitu-la helu Tou-loa: "bòso huka kama-kama-la lai uma lia dalẹ!» Makasososa-na Tou-loa namahèle paleta nitu sila, te mai ina-falu-a namalasi bòe ma ana huka kama esa, tè doi ngèo mesan, ana neu selụ kama esa, tè doi fulạ mesan. Bòe-ma ngòe sụ kama sila, hu nitu sila sanga fali sò. Nitu-la mai na Tou-loa fè lâ linu lakabète. Nitu-la lako lasadea, ana neu huka kama ia-la selụ, neu kama esa nita kảda doi pilạ mesan. Ma ana neu kama makabuik-a, ana nita ina-manẹ esa nai dalẹ. Nitu kahitụ ia-la lamanako leni manẹ esa nai dulu 
ana-fèto-na, dè leni-n ana neu losa kama lia dè ala paka langadò-na neu uma dodoi-na ma ala lolòke naka besi esa nai ei-na. Tou-loa nita inạ ia bòe ma ana bebesa nitu-la papake-na, basa bòe ma ana sefi heni papakạ sila. Nitu-la sanga fali ana neu paka selụ. Nitu-la lako lasadea. Tou-loa neu sefi selụ. Neu fai esa inak-a balakai nala ao-na bòe ma dua-s-ala huka kama doi pilak-a, dua-s-ala lepạ lèo kofak-a leu. Bòe-ma dua-s-ala tipa kofak-a lèo deạ neu dè ala sake. Lai-lai Tou-loa lofa la-a neu ma sèse memạ popoka kahituk-ala. Nitu kahituk-ala leu lamanako losa lai èno taladạ boè ma lameda-lá Tou-loa tao ta malòle nai uma-a sò, hu lia dè nitu-la basa-basạ fali lèo uma leu, tè lita uma-a kama-na nanahukạ ma inak-a Tou-lia nalai neni-n sò ma ina-falu-a lenga-lenga nai pepeụ lain, ta nakababale neni ao-na sò bòe. Bòe-ma nitu kahituk-ala sake lala-ani dè leu tunga Touloa nò inạ lia. Nitu ia-la fè lala-la lapalelète lesị tasi-òẹ lain, tè Tou-loa bei nita nitu-la mai mata bòe ma ana dède popoka esa dè nitu uluk-a tuda dè mate-n. Lèo-lèo-lia ana silo nisa basa-basa nitu kahitụ sila.

Bòe-ma dua-s-ala leu losa dae-inạ esạ, nai lia ala hapu kofa dodoụ nafu nai namo lia. Dua-s-ala nafu sila kofa-na bòe ma Tou-loa kona neu nakaneni nusạ lia. Tèbe Tou-loa neni doi lilo-pila dodoụ, tè ana ta nau asa bua malòle fò ana pake neu ao-na. Ana kona lèo dae-inạ neu na ana neni doị henu sakubadu-na, fo ana asa lalu nò tia-lai-n-ala linu mafụ ma lenạ bau-bea na ana tuku henị tè ta na ana fè henị leu dahenadahena-la. Mai faị esa ana lako-lako nème dae-inạ dè neu hapu tou manamatẹ esa lapeuk-ana nai èno-ina lain, fò kela bea lakọ nesị lia na dahena manalakọ lia mèste tabu nesị lain, ma ala fè dahena sio lanea, makaneni-ma dahena bea lakọ nesị lia na ana ta tabu nesị tou manamatẹ lia lain, na dahena manamanea sila paka toụ lia fò lò-n ana lèo uma kekenak-a neu. Lake Tou-loa lakọ tunga ia, bòe-ma Tou-loa ta nau tabu nesị tou manamatẹ lia lain dè natané tou manamanea-la nae: "tè hu dubea dè au mèste tabu tou manamatẹ ia ?» Dahena manamaneala lae: "mane manakoasạ ana fè paleta nae: toụ ia nahuta dọ̣ lifun falu, hu lia dè ami tao-n ana neu ènọ lain fò bea lakọ nesị ia na ana mèste tabu toụ lia, makaneni-ma bea ta tabu-n ana, na ana tifa hutạ sila lifun falu, tè makaneni-ma ana ta tifa na mahani paka mò-n ana lèo uma kekenạ neu.» Tou-loa namanène lia bòe ma nae: "meu mafada manek-a mae au D1. 68 . 
sanga tifa hutạ sila ma au dei fè dọ̣ fò ala latoi tou manamatẹ ia.» Leu lafada manek-a dè manek-a nadenu ana-uma-dale-n-ala leu tunga Tou-loa nai kofạ dè ana fè doi lilo-pilạ alukosu sio. Ma ana neni doị selụ fò sanga neu seba dahena latoi tou manamatẹ lia.

Mai fạ esa bòe-ma kofa-ai esa nème dulu mai, ana mai neni dedeạ, uni manẹ manai nusa-dulu ana fè kofa-ai natun esa ma esa leu sanga ana-fèto-na. Na mane musa-dulu-a ana helu nae makaneni-ma bea hapu au ana-ng lia na au fè dua-s-ala sao. Tou-loa neni inak-a li-lia mane nusa-dulu-a ana-fèto-na. Lai-lai inạ ia tao nala kai-bunạ esa dè ana paka-n nai ò esa peda-na, fè anạ esa neni-n lèo kofa-ai lain neu ma neni susulạ esa. Nai susulạ lia dalẹ nafada nae mèste fè anạ ia dọ̣ lopia natun lima. Anạ ia neu dè ana hapu dọ̣ sila dè namahòko ta hohokạ. Mai fai-a nalá bòe ma manahopu-kofa-ai-a ana haitua susulạ fè Touloa nò inạ lia mai sake lèon. Bòe-ma Tou-loa nò inak-a dua-sala leu sake lala kofạ lain, dè manahopu-kofa-ai-a ana nadenu hela naka fò sanga lako lèon. Manahopu-kofa-ai-a ana nita inạ ia lòle-na seli, hu lia dè ana sanga aäfị fò nae nisa Tou-Loa. Manahopu-kofa-ai-a ana helu kofa-isik-a nae: "kemi lelu matalolòle tou-ana manade Tou-loa lia, fò ana lakọ tunga kofak-a su-na, na soli heni-n ana lèo tasi-òe dale neu !» Dè kofa-isik-ala soli heni Tou-loa lèo tasi-òẹ dale neu, fò kela leu losa nusa dulu, na mane nusa-dulu-a fè manahopu-kofạ lia nò ana-n dua-sala sao. Tou manamatek-a samane-na dadi neu ika bau-ina esa dè lake fạ lia kofa-ai-a sanga lako, ikak-a tunga-tunga dea, dè kofa-isik-ala soli heni Tou-loa lèo tasi-òẹ dale neu, bòe ma ikak-a kòdo Tou-loa lèo tei-n dale neu. Ikạ ia nalai neni Tou-loa lèo nusa dulu neu dè ana muta Tou-loa lèo dea mai nème tasisúk-a manatia oli-bafak-a. Dè Tou-loa neu sanga naná-nininụ. Losa fạ telu bòe ma besak-a kofa-ai-a losa namo lia dè ana poka, fò kela manek-a namanène lia fua nò manek-a ana-fèto-na nai ia sò. Ma manek-a poka bòe, hu nalelạ nae ana-fèto-na fali sò. Manahopu-kofa-ai-a ana kokòe-doạ inạ ia, hu inạ ia sue Tou-loa. Nanalek-a leu lafada manek-a lae ana-fèto-na ta nau kona $\mathrm{fa}$, hu lia dè manek-a neu lelèko matalolòle-n, besak-a ana-na kona. Mane nusa dulu nò namahòko-na ana tao feta fạ hitu. Feta basa fai kahitụ sila bòe ma manahopu-kofạ lia neu hule manek-a, fò kela lia sao manek-a ana-fèto-na. Bòe-ma mane nusa dulu ana poi paleta fè basa-basa dahena nusa-dulu-la 
lalake-na nae: "basa-basa-ngemi mai fò kela ata tamahòko belabela tò ina-manek-a, hu ta dòk-a tè au fè-n ana nò manahopukofa-ai lia sao.» Basa-basa dahena nusa dulu-la lalake-na mai lakabua tao feta matua. Fai-a nalá bòe ma sanga fè dua-s-ala sao. Lake fạ lia Tou-loa neu nanilu dahena tua-inạ sila, ta dò bea bòe ma inạ ia titino nita Tou-loa dè ana nalai kela manahopu-kofa-ai-a nème lia tè ana hela nala Tou-loa nò-n ana lèo ama-na mata-na neu, dè nae ama-na nae: "touk-a lia ia, besak-a au dadi dahena, tè ami mai tasị lain dè manahopu-kofạ ia nadenu kofa-isik-ala soli heni-n ana lèo tasị dale neu.» Inạ ia tui ama-na nème nitu kahitụ sila lalai leni-n ana losa Tou-loa neu besak-a ana nalai nò falị sụ au.» Basa bòe ma ama-na nalò basa-basa lasi-nusak-ala dè ala tai dedeạ lia ana dadi tao lèobea. Dè basa lasi-nusak-ala kè dedeạ lia lae mèste huku manahopu-kofạ lia, toụ lia tou takadalụ. Hu lia dè manek-a nadenu ala lona tou manahopu-kofa-ai lia neu kai esa lain fè langa-na dodòko nesị dae, ta dò bea bòe ma manek-a nadenu silo lisa-n ana. Tou-loa nò inạ lia dua-s-ala sao, dè Tou-loa nae nò sao-na lèo Tou-loa nusa-na neu, tè mane manai nusa dulu-a ana ta nau Tou-loa lako kela-n ana, hu lia dè Tou-loa lèo nò kalamana losa dodò-na neu. Dè mane nusa-dulu-a ana fè Tou-loa hopu basa-basa lia suki-n-ala lalake-n. Hu lia dè Tou-loa lèo nò sao-na ta toka hata esa bòe.

Er wordt verhaald van een blinden Koning, die in het West-land woonde, (door J. M. Baleno).

In het West-land was een vorst, genaamd Kai-oöe ${ }^{1}$; deze vorst had twee zoons, die tweelingen waren; de een heette Naloe-fai ${ }^{2}$, de andere Loa-lèdo ${ }^{2}$; maar deze vorst was al oud en hij wist niet, wie van zijne zoons in zijne plaats vorst zou moeten worden. Hij werd steeds ouder en blind en doof, zijn haar werd wit en zijne tanden vielen uit, hij zag of hoorde niets meer. Daarna verzamelden zich, op een dag, alle rijksgrooten in de woning van den vorst om te beraadslagen, wat

1 De naam beteekent: tjĕmara-boom.

2 Nalu-fai, wiens dag of tijd lang is, die een lang leven heeft, Loalèdo, idem, (lèdo, in namen, evenals nog in de dichtertaal, zonder slot- $k$ of ingeslokten medeklinker voor lèdok, lèdo) =faik, fai, dag, loak, loa, eigenlijk: breed, maar wegens het parallellisme genomen $=\mathrm{naluk}, \mathrm{nalu}$, lang. 
er aan te doen zou zijn, dat de oogen van den vorst (weer) ziende werden. Niet lang daarna zeide een oude man: "ik heb hooren zeggen, dat, als de vorst een zekeren vogel hoort zingen, zijne oogen (weder) ziende zullen worden.» Toen de vorst dit gezegde vernam, sprak hij: "ik vaardig een bevel uit: indien iemand, wie ook, dien vogel hier brengt en hij zingt, en mijne oogen worden ziende, dan zal hij in mijne plaats vorst worden en mijne rijkdommen zal ik alle in zijne handen geven.» De beide zoons van den vorst zeiden tot elkander: "laat ons eens nadenken, want als wij dien vogel niet gaan zoeken, dan zal geen van ons beiden vorst worden, maar, al is 't ook een geheel vreemde, als hij dien vogel zoekt en brengt, dan zal hij vorst worden en wederom over ons beiden regeeren. Laten wij dus gaan zoeken, want wij beiden zijn vorstenzoons, wellicht zal de Heer zich over een van ons beiden erbarmen, zoodat hij dien vogel vindt, (wie van ons beiden het ook zij); als de staf van den vorst, (als teeken van waardigheid), maar niet in andere handen overgaat».

En beiden zeiden tot hunne ouders, dat zij leeftocht voor hen gereed moesten maken. Toen de dag (voor het vertrek) aangebroken was, namen zij leeftocht, geld en kleeren in ontvangst en gingen op den zoek van dien vogel. Toen zij bij een kruisweg kwamen, haalden zij de leeftocht te voorschijn en aten en dronken, en zij namen afscheid en kusten elkander, toen scheidden zij. Naloe-fai volgde den weg, welke rechts (of naar het Zuiden) liep, Loa-lèdo den weg, welke links (of naar het Noorden) liep. Naloe-fai ging steeds voort tot hij aan een dorp kwam en trof de lieden daar aan, terwijl zij op de gong sloegen en jenever in groote hoeveelheid dronken. En hij kocht drank en dronk met al de lieden tot zij dronken waren. Zoo ging het voort tot zijn geld op was en hij al zijne kleeren verkocht had.

Loa-lèdo volgde den anderen weg en kwam bij een dorp; dat dorp was nog onderhoorig aan zijn vader. Toen de prins in dat dorp gekomen was, ging hij naar het huis van eene

1 Nakamè wordt hier steeds gebezigd voor het zingen van den vogel. Eigenlijk wordt het woord alleen gezegd van het zingen van menschen in de kerk, bij uitbreiding ook wel (in plaats van soda) voor zingen in 't algemeen. Het moet hier aanduiden, dat de vogel niet op de gewone wijze, (waarvoor de woorden dasi, kako, enz. bestaan), maar op meer menschelijke wijze zong. 
weduwe. Hij sprak tot haar: "moeder, heb medelijden met mij, geef mij, als 't $u$ belieft, wat water te drinken, want ik ben dorstig». De weduwe ging water scheppen en bracht het hem in een glas en gaf het hem te drinken, maar zij wist niet, dat die jongeling de zoon van den vorst was. De prins zag naar de rustbank en zag daar een man op liggen. Deze man lag evenwel niet te slapen, maar hij was al lang gestorven; hij was echter aan de lieden van het dorp veel geld en goed schuldig, daarom wilden zij hem niet begraven. De weduwe vertelde dat alles aan den prins, en deze beval haar al die lieden te ontbieden: "opdat ik de schuld van den doode betale». De weduwe en de weezen gingen snel heen en riepen al de verschillende menschen, en de prins betaalde hen tot al zijn geld op was; toen haalde hij zijne goederen of kleeren te voorschijn om (daarmede) verder te betalen. Maar de menschen herkenden die als toebehoorende aan een vorst, (en wel) aan hunnen vorst, en zij dachten: "denkelijk is dit een der zoons van onzen vorst". Zoodra zij den prins herkend hadden, zeiden zij tot hem: "wij willen niet, dat $\mathrm{u}^{1}$ ons betaalt; wij zullen den doode maar begraven». Daarop maakten de lieden van het dorp zich te samen op en gingen een kuil graven en eene kist maken; daarop gingen zij den doode begraven. Nadat deze begraven was, ging de prins wederom naar een ander land om dien vogel te zoeken. Toen hij bij een vijgenboom kwam, rustte hij aldaar en wilde van de vruchten eten. Nadat hij korten tijd gerust had, plukte hij de rijpe vruchten en at daarvan. Nadat hij eene vrucht gegeten had, haalde hij diep adem, (zuchtte hij), en zoo tot negen maal toe. Velé vogels kwamen van de vruchten van dien vijgenboom eten; een zwarte vogel in den top zag dat de prins veel zorg had, toen vroeg hij hem: "prins, waarover zijt gij bekommerd?» Toen verhaalde de prins van het begin af, hoe het kwam, dat hij hier gekomen was. De vogel sprak: "wees niet bevreesd, want gij zult dien vogel vinden. Gij moet door dit woud gaan tot gij in gindsche vlakte zijt uitgekomen, aldaar zult gij een met steenen ommuurd verblijf zien, daar verzorgt eene gevleugelde vrouw dien vogel; maar ik waarschuw $\mathrm{u}$, als gij daarheen gaat, zult gij twee roode slangen zien, welke de poort bewaken. Als gij ziet, dat hunne oogen open

1 Mane voor au mane-nga, mijn vorst, of ita mane-na, onze vorst, hier als voornwd. gebruikt; gewoon is dit gebruik evenwel niet. 
zijn, ga dan rechtdoor, maar als hunne oogen gesloten zijn, ga dan niet, want dan zijn de slangen wakker. Die twee slangen bewaken de vrouw en dien vogel ter dege. Als gij de vrouw en den vogel gevonden en uw land (weer) bereikt hebt en daar vorst zijt geworden in plaats van uwen vader, denk dan aan mij, opdat wij te zamen al uwe rijkdommen deelen. Toen antwoordde de prins: "dat is goed». En hij drong maar steeds dwars door het bosch voort, en toen hij in de vlakte kwam, zag hij een ommuurd gebouw en hij ging op de poort af. Daar gekomen zag hij, dat de oogen der beide slangen geopend waren en hij zeide (bij zich-zelf): de slangen zijn niet wakker, zij zijn in diepen slaap». En hij ging recht door de ommuring binnen. Toen hij bij de huisdeur kwam, rook de gevleugelde vrouw eene ongewone lucht in het voorhuis; snel ontbond zij het bindsel, waarmede de deur vastgebonden was en zij zag Loa-lèdo. Zoodra deze met verbazing de schoonheid van deze vrouw zag, stortte hij neder en verloor het bewustzijn. Snel nam de vrouw hem op, droeg hem en bracht hem in huis en behandelde hem met geneesmiddelen tot zijn oog (weder) helder was, (tot hij weder tot bewustzijn kwam). Toen vroeg zij hem: "hoe komt het, dat gij hier zijt terecht gekomen?» En hij verhaalde van het begin af, hoe dat kwam. Toen zij zijn geheele verhaal gehoord had, was zij verheugd, en knipte zijne nagels en sneed zijn haar. Daarna deed zij hem mooie kleeren aantrekken. De zingende vogel was ook daar, en toen hij gehoord had, waarover gesproken was, verheugde hij zich; nu eens vloog hij naar de gevleugelde vrouw, dan weer naar den vorstenzoon. Toen het zoo juist drie jaar geduurd had, zochten zij een gunstigen dag uit om te vertrekken. Op een dag zag de vrouw, dat de oogen der twee slangen geopend waren en zij opende de deur van het huis en ging naar buiten met den prins en den vogel en met hun drieën trokken zij snel voort. Toen zij halverwege gekomen waren, wisselde de gevleugelde vrouw met den prins van ring. $\mathrm{Zij}$ trokken met hun drieën al verder voort, tot zij aan den kruisweg kwamen, waar de beiden prinsen gerust hadden om te eten en te drinken; toen zeide Loa-lèdo tot de vrouw: "ik en mijn broeder; wij zijn op deze plaats gescheiden, maar wij hebben afgesproken, dat wij hier op elkander zouden wachten». De vrouw vond goed wat de prins zeide en zij bleven wachten. 
Niet lang daarna kwam Naloe-fai uit dat dorp, maar hij bracht niets mede; hij zocht evenwel een middel om zijn broeder te dooden. Toen hij kwam, zeide hij: «ik heb dorst, laat de vrouw met den vogel hier achter en laten wij wat drinkwater gaan zoeken!» Loa-lèdo geloofde wat zijn broeder zeide; zij gingen dan drinkwater zoeken. Werkelijk vonden zij eene bron, vijf-entwintig vademen diep. Naloe-fai bond lianen aanéén en bond aan het uiteinde daarvan een blik en liet zijn broeder putten. Terwijl deze aan het putten was, ging hij achter hem staan en stootte hem in de bron en liet hem daar achter op het punt van te sterven. En hij ging met de gevleugelde vrouw en den zingenden vogel naar zijn land. Toen hij in de woning van zijn vader, vorst Kai-oöe gekomen was, zeide hij tot hem: «ik heb dien vogel gevonden». Maar de vogel wilde niet zingen, opdat de oogen van den vorst ziende werden. Elken dag was hij geheel verstomd $^{1}$ en de vrouw was als verdwaasd, daarom bleef zij met den vogel in het vertrek van Loa-lèdo en alle dagen was de deur van het vertrek gesloten.

De vogel, die in den top van dien vijgenboom was, veranderde zich in een Hollandschen heer en ging aan den rand van de bron staan en liet voor Loa-lèdo (aaneengevoegde) lianen naar beneden, maar deze sprak: "misschien breekt de liaan, zoodat ik val en sterf». De Hollander sprak: "grijp maar stevig vast!» Hij greep de liaan stevig vast en de Hollander trok hem op. Deze sprak nu met hem af: "ga nu naar uw land en als gij uw bord rijst ${ }^{2}$ zult hebben, denk dan aan mij, en als men $u$ tot vorst heeft verheven, dan zullen wij al uwe bezittingen gelijkelijk verdeelen.» Loa-lède zeide: "het is goed». Hij ging nog niet naar zijn huis, maar naar de markt van de stad en zocht werk. Hij zag er niet uit als een prins, het water had hem zoo doorweekt, dat hij leelijk was en zijne huid gerimpeld. Toen hij op de markt kwam, zag hij de kookster van zijn

\footnotetext{
1 Namangoa-k-ana, (Term. namanggoa-k-ana), wat gewoonlijk beteekent: hij staat verstomd $=\mathrm{hij}$ is stom van verbazing, is bier in de eigenlijke beteekenis gebezigd.

2 De uitdrukking is natuurlijk geen Rottineesche, (zuiver Rott. is: hapu lia tei-na). Maar ook als vertaling deugt kò kakau-pinga-ma volstrekt niet; het zou dan moeten zijn: kò kakau-ma pinga esa of kò pinga-ma henu kakau. Kakau-pinga kan niets anders beteekenen dan een soort pap, geschikt voor een bord of iets dergelijks.
} 
vader en sprak: "moeder, ik zal u volgen en gij kunt mij bevelen voor $u$ werk te doen, als potten wasschen of wat ook, mits gij mij voldoende te eten geeft, zelfs aangebrande rijst gaat, (is voldoende). De vrouw sprak: "het kan wel, als gij wilt, laten wij dan gaan!» Hij volgde haar en als hij het een of ander verkeerd deed, sloeg zij hem. Zoo ging het steeds elken dag. De gevleugelde vrouw, die in de kamer was, wist dat hij teruggekomen was, daarom vroeg zij aan de kookster om rijstepap. Deze beval hem een pot om te wasschen en liet hem pap koken. Toen hij de pap klaargemaakt had, beval zij hem die op een bord te scheppen en om te roeren, opdat zij zou bekoelen. Toen deed Loa-lèdo den ring af, welken de gevleugelde vrouw hem gegeven had en deed die in de pap. De kookster nam de pap en gaf die aan de vrouw. Toen deze ze omroerde, zag zij den ring en zeide: "Loa-lèdo is werkelijk teruggekomen.» Des nachts opende zij (de deur van) het huis, droeg Loa-lèdo binnen om hem te baden en gaf hem nieuwe kleederen. Den volgenden dag toen de kookster den prins zag, herkende zij hem en sprak: "prins, wees niet boos, dat ik u al dien tijd bevolen heb de potten om te wasschen, want ik wist niet, dat gij de prins waart.» De prins zeide: "neen, ik ben niet boos». De zingende vogel zong aanhoudend uit vreugde en de prins ging zijn vader mededeelen: «ik ben teruggekomen, ik heb den zingenden vogel hier medegebracht». Zoodra zijn vader het stemgeluid van den vogel hoorde, werden zijne oogen ziende. $\mathrm{Al}$ de oudsten kwamen en zij verhieven Loa-lèdo tot vorst in de plaats van zijn vader en Naloe-fai, den slechtaard, dewijl hij zijn broeder had willen dooden, gingen zij werpen in eene bron, welke dertig vademen diep was; indien hij onschuldig was, als zijn broeder, zou hij er het leven afbrengen, als hij schuldig was, zou hij sterven. Bij de bron gekomen, wierpen zij hem er in. Op een dag kwam de heer, die Loalèdo uit de bron had geholpen, opdat zij te zamen de landen en alle bezittingen zouden deelen. Loa-lèdo herinnerde zich hem niet meer; eerst toen de Hollander het hem nauwkeurig had verhaald, herinnerde hij het zich, en zij verdeelden ze juist in tweeën. Toen alles verdeeld was, bleef nog de gevleugelde vrouw over. Toen trok Loa-lèdo zijn zwaard en wilde haar in tweeën houwen. De Hollander sprak: «laat dit; ik ben hier gekomen om $\mathrm{u}$ op de proef te stellen, of gij mij liefhebt of niet, ik 
zie nu, dat gij mij liefhebt, zoo dat gij zelfs die vrouw in tweeën wilt houwen, dus schenk ik u alles.» Zoodra hij aldus gesproken had, verdween hij. Loa-lèdo en de vrouw huwden met elkander. Niet lang nadat zij gehuwd waren, werd de vrouw zwanger en zij baarde een zoon, dien zij Toöe-Loa ${ }^{1}$. Toen dit kind groot was, wilde het niet hooren naar de bevelen zijner ouders, het wilde maar steeds ${ }^{2}$ in de verschillende landen rondzwerven. Eens op een dag, toen hij terugkeerde uit een ver afgelegen land, waren zijne ouders gestorven en had men een ander tot vorst verheven en kon hij dus niet meer vorst worden in de plaats van zijn vader. Daarna, nadat hij alle bezittingen van zijne ouders doorgebracht had, ging hij voor loon dienen op een zeil-vaartuig. Maar hij sprak af met den eigenaar: "als mijn tijd om is, hetzij wij midden in zee zijn dan wel aan land, op dien dag moet gij mij vrijlaten.» Op den dag, waarop zijn tijd bijna verstreken was, dobberde hun vaartuig midden in zee. Toen zijn tijd om was, deed hij allen, die de bemanning van het vaartuig uitmaakten, bijeenkomen en hij onderhield zich met hen en nam afscheid van hen en sprak: "ik moet heden van boord gaan, want van het begin af heb ik afgesproken, dat als mijn tijd om zou zijn, ik dienzelfden dag moet vertrekken.» Allen op het schip en (ook) de eigenaar zochten hem over te halen (om te blijven) en zeiden: "wij zijn in volle zee, ga dus niet heen, wij zullen u niets laten doen, gij behoeft alleen maar te eten en te drinken en na afloop van de maand zult gij uw loon voluit krijgen.s Maar toch wilde hij niet en hij nam zijn pak op en sprong in zee en bleef daar rondzwemmen. Maar de eigenaar van het vaartuig kreeg weder medelijden met hem en wenkte hem om terug te keeren. Toen hij kwam, gaven zij hem een schuitje om dat alleen te bevaren. En hij kreeg dat schuitje met zeven kanonnen er op. Spoedig daarop ging hij den eenen ksant uit, en het groote vaartuig een anderen.

Toöe-loa bereikte een eiland, maar menschen vond hij er niet op. Aan eene riviermonding gekomen liet hij het bootje daar ankeren en liet het daar met alle kanonnen er op. Toen hij aan den Noord-kant van het eiland kwam, zag hij in de verte een huis met gěbang-bladeren gedekt, en begaf hij zich daar-

\footnotetext{
1 D. i. een zoon (tou-ana) uit het geslacht van Loa(-lèdo).

$2 \mathrm{Sudi}$, afschoon als een verbum geconstruëerd, is hier ongeveer gelijk aan sadi, alleen maar.
} 
heen. Dat huis nu werd bewoond door zeven duivels, maar gelukkig toen Toöe-loa kwam, waren zij afwezig; zij waren uit stelen gegaan in een verafgelegen land. Toen hij het huis binnentrad, zag hij eene weduwe. Deze sprak tot hem: "het is uw lot, (gij zijt wel ongelukkig), knaap, als de duivels terugkomen, zullen zij u verslinden, (al) zijt gij niet eens voldoende voor hunne snijtanden». Maar de vrouw was zeer vindingrijk, daarom deed $\mathrm{zij}$ hem, toen de dag van den terugkeer der duivels aanbrak in eene kist, waaromheen acht andere kisten waren en sloot 't geheel met een sleutel goed toe. Toen de zeven duivels terugkeerden, roken zij eene ongewone lucht in het huis, maar de vrouw ontkende dit en zeide dat het niet zoo was. Maar de lucht van dien mensch, nam. Toöe-loa, prikkelde zeer in hunne neusgaten, zoodat, toen hunne jachthonden die lucht roken, zij met alle geweld wilden bijten. De duivels ondervroegen de vrouw, zoodat zij ten slotte antwoordde: "het is waar». Zij zocht de duivels over te halen om Toöe-loa niet te dooden: "want ik ben al oud, als gij met uw zevenen terugkeert van den kost te zoeken, wie zal dan voor u koken? De oudste der duivels (sprak): "waar is die mensch, breng hem hier, dat ik hem verslinde». De jongste sprak: "broeder, doe dat niet, denk eens goed na, deze vrouw is al oud». Ten langeleste zeiden (al) de zeven duivels: "het is waar». De vrouw ging nu heen en ging nu de kist openen en Toöe-loa kwam er uit en at en dronk te zamen met hen. Als de bepaalde tijd aanbrak, gingen de duivels uit om te stelen, zeven dagen lang, dan eerst keerden zij terug. Op een keer bleven Toöe-loa en de weduwe achter om op het huis te passen. En de duivels hadden hem gewaarschuwd om de kamers van het huis niet te openen. In den beginne had hij dit bevel opgevolgd, maar naderhand, toen de weduwe (al) ouder werd, opende hij een vertrek en het was alles kopergeld, (wat daarin was); hij opende nog eene kamer, en 't was er vol met zilvergeld. Toen sloot hij die kamers weder toe, omdat de duivels op het punt waren terug ste keeren. Toen zij kwamen, liet hij hen volop eten en drinken. Nadat zij (weer) vertrokken waren, opende hij de kamers wederom; in eene was niets anders dan goudgeld. Toen hij zich naar het achterste vertrek begeven had, zag hij daarin eene prinses. De duivels hadden de dochter van een vorst in het Oosten ontvoerd en haar in die kamer gebracht en hare 
haren vastgebonden aan de daksparren en een ijzeren anker gehangen aan hare voeten. Toen Toöe-loa deze vrouw zag, keek hij nauwlettend toe, hoe de duivels haar gebonden hadden, daarna maakte hij de banden los. Toen de duivels op het punt waren terug te keeren, bond hij haar weder. Na hun vertrek maakte hij haar weer los. Op een dag, toen zij weder sterk geworden was, openden zij met hun beiden de kamer waar het goud in was en droegen de goudstukken naar het vaartuig. Toen duwden $z 1 j$ het vaartuig in zee en gingen scheep. Snel maakte Toöe-loa de zeilen los en laadde vooraf al de kanonnen. Toen de zeven duivels, die waren gaan stelen, halverwege gekomen waren, kregen zij er een voorgevoel van, dat Toöe-loa iets niet goeds in huis uitvoerde, daarom keerden zij altemaal naar huis terug, maar zagen, dat de kamer geopend en Toöe-loa met de prinses gevlucht was, terwijl de weduwe achterover op bed lạg en zich niet meer verroerde. De zeven duivels bestegen wind-paarden en achtervolgden hen. Zij lieten de paarden over de zee gaan, maar zoodra Toöe-loa hen zag naderkomen, schoot hij een kanon af en de oudste der duivels viel en stierf. Zoo schoot hij achtereenvolgens alle zeven duivels dood.

Toen bereikten zij een vast land, alwaar zij op de reede vele vaartuigen aantroffen, welke daar voor anker lagen. $\mathrm{Zij}$ deden (ook) hun vaartuig ankeren en Toöe-loa ging aan land om die stad te bezien. Weliswaar nam hij veel goudgeld mede, maar hij wilde geen mooie dingen koopen om die te dragen. Als hij aan land ging, nam hij de zakken van zijn jas vol geld mede om sagoeweer te koopen, waarvan hij dan met zijne makkers dronk tot zij dronken waren; zoovele geldstukken als er overbleven, strooide hij voor de menschen, of hij gaf ze hun ten geschenke. Op een dag, dat hij aan land wandelde, zag hij een dooden man, dien men op den grooten weg uitgestrekt had, opdat, als iemand daar langs ging, hij op den doode zou trappen; en men had er negen mannen bij op wacht gezet; indien iemand daarlangs kwam en hij trapte niet op den doode, dan bonden de wachters hem en brachten hem naar de gevangenis. Toen Toöe-loa daar toevallig langs ging, wilde hij niet op den doode trappen en vroeg aan de wachters: "waarom moet ik op dezen doode trappen?» De wachters zeiden: "de vorst, die hier regeert, heeft het (volgende) bevolen: "wijl deze man acht duizend schuld heeft, moesten wij hem op den weg leggen, opdat ieder, 
die hier voorbij gaat op hem trappe; als iemand dat niet doet, dan moet hij die schuld van acht-duizend betalen; betaalt hij niet, dan moeten wij hem binden en naar de gevangenis brengen». Toen Toöe-loa dit hoorde, zeide hij: "gaat aan den vorst zeggen, dat ik die schulden zal betalen en dat ik geld zal geven, opdat men dezen doode begrave». Zij gingen het den vorst zeggen en deze beval zijne dienaren om Toöe-loa te volgen naar het schip, en hij gaf hun negen beurzen vol goud. En hij nam ook nog geld om menschen te huren, die den doode begroeven.

Daarna kwam er op een dag eene stoomboot uit het Oosten en bracht het bericht, dat de vorst van het Oost-land honderden-een stoomschepen uitgezonden had om zijne dochter te zoeken. En de vorst had bekend gemaakt: "als iemand mijne dochter vindt, zal ik ze te zamen in het huwelijk doen treden». De prinses, die Toöe-loa medevoerde, was de dochter van den vorst van het Oostland. Fluks nam zij eene bloem en nadat zij die op de punt van een bamboe gebonden had, liet zij die door een jongen naar het stoomschip brengen, tevens nam hij een brief mede. In dien brief zeide zij, dat men hem vijfhonderd gulden moest geven. Toen de jongen daar gekomen was, kreeg hij dat geld en was zeer verheugd. Toen de tijd (voor het vertrek) aanbrak, zond de gezagvoerder van het stoomschip een brief aan Toöe-loa en aan de prinses, dat zij aan boord moesten komen. En beiden begaven zich aan boord en de gezagvoerder beval het anker te lichten om te vertrekken. Toen de gezagvoerder zag, dat de prinses zeer schoon was, bedacht hij een middel om Toöe-loa te dooden. Hij gaf aan de opvarenden de (volgende) opdracht: "ziet goed toe op den jongeling Toöeloa, als hij langs den rand van het vaartuig gaat, stoot hem dan in zee!» En de opvarenden stootten hem in zee, opdat, als zij het Oost-land bereikten, de vorst den gezagvoerder met zijne dochter zou doen huwen.

De ziel van den doode was een groote visch geworden en het trof, dat op den dag, waarop het stoomschip vertrok, de visch het steeds volgde en toen de opvarenden Toöe-loa in zee stootten, slokte de visch hem in. De visch voerde hem snel naar het Oost-land en braakte hem uit aan het strand, dicht bij de rivier-monding en hij ging eten en drinken zoeken.

Eerst drie dagen later kwam het stoomschip aan en het gaf een kanonschot, opdat de vorst zou vernemen, dat het de 
dochter van den vorst medegevoerd had. En de vorst liet ook een schot geven, omdat hij wist, dat zijne dochter teruggekeerd was. De gezagvoerder deed te vergeefs pogingen om de prinses gunstig te stemmen, omdat zij van Toöe-loa hield. Het was gelukkig, dat men den vorst mededeelde, dat zijne dochter niet aan land wilde gaan, daarom ging de vorst heen en deed zijn uiterste best om haar daartoe over te halen, toen eerst wilde zij aan land gaan. De vorst van het Oost-land gaf in zijne vreugde een feest van zeven dagen. $\mathrm{Na}$ afloop daarvan ging de gezagvoerder den vorst verzoeken hem zijne dochter ten huwelijk te geven. En de vorst van het Oost-land vaardigde het volgende bevel uit aan alle bewoners van het land: "Komt allen, opdat wij ons te zamen verheugen met de prinses, want binnenkort zal ik haar met dien gezagvoerder laten trouwen.» $\mathrm{Al}$ de menschen kwamen te zamen en zij richtten een groot feest aan. Toen de tijd aanbrak, dat zij in het huwelijk vereenigd zouden worden, trof het, dat Toöe-loa dien dag naar de menigte ging kijken; na korten tijd zag de prinses hem en snelde op hem toe, terwijl zij den gezagvoerder daar liet staan en trok hem mede naar haren vader en sprak tot dezen: "deze man kwam en toen eerst ben ik mensch geworden, (eerst toen deze kwam, ben ik bevrijd), maar toen wij op zee waren, heeft deze gezagvoerder den opvarenden bevolen hem in zee te stooten.» $Z$ ij verhaalde haren vader vanaf dat de zeven duivels haar ontvoerd hadden, tot dat Toöe-loa kwam en haar terugvoerde. Daarop riep haar vader al de oudsten van het land op en zij overwogen, hoe die zaak was. En zij beslisten, dat de gezagvoerder gestraft moest worden, dewijl hij een slechtaard was. Daarom beval de vorst hem aan een boom op te hangen met zijn hoofd afhangende (naar beneden) en niet lang daarna beval de vorst hem dood te schieten. Toöe-loa huwde met de prinses en hij wilde met haar naar zijn land terugkeeren, maar de vorst van het Oost-land wilde niet, dat Toöe-loa hem verliet, daarom bleef hij voor altijd bij zijn schoonvader wonen. En de vorst stelde hem in het bezit van al zijne schatten. Derhalve woonde Toöe-loa (aldaar) met zijne vrouw en ontbrak hun niets. 


\section{Dialect van Ringgou, (Rainggou, Lainggou of Raikou).}

$$
\text { Manu-pui doá-a nò lafì-a. }
$$

Matutuị-a nafada nae uni manu-pui doá esa natiạ nò lafo esa. Neu faị esa bòe ma matia-lai kaduạ sira saë rala ofa-dodolu tane esa dè reu ramadolu.

Dè doá-a nesị ofa-laka dadi duru-batu ma lafo-a nesị ofa-bui dadi maulị, dè lahenda matia-lai kaduạ sira ramadolu rò dale namahòö.

Dè malòle-a sò, tè hu maneni-ma lea rala ikạ esa nala ofạ dale na bai-lafọ-a naisi heni rou-na, fò nâ heni isi-na, besạ-é napalu selụ ika-roụ-a neu dui-na.

Dè bai-lafọ-a oda ada nanâ ikạ-a losa ria nò tia-na ramadolu ratèë-a. Mabuị dè doá-a relu neu tè ikạ henu ofạ-a sò, bòe-ma nafada neu lafo-a nae: "malòle lena fali teu-kita lèon, tia, tè ita ofa-na ikạ henu-n ana sò.» Bòe-ma lafo-a natá. "malòle-a, tia!»

Bòe-ma doá-a hai nala ikạ-ara fò nae bati neu dua-s ', tè hu doá-a bei hai nala ikạ-ara bòe ma ana relu neu tè ikạ-ara esa ta maisị bòe-n tè basa-basa-s ada noi ika-dui mananapalụ ${ }^{2}$ nò ika-roụ mesa-mesan. Bòe-ma doá-a natane nò balanaụ neu bailafọ-a nae: "ò tia, tè basa-basa ikạ-ara isi-n-ara bea reu ?» Bòema lafo-a natá nò nasạ ma nae: "au ta bubulụ losa na fa ma ò malelạ mala-n, au ia maulị ma ta manamanea ikạ fa.»

Bòe-ma doá-a bòe-bòe namanasa hu nalelạ nala-n nae ta selụ esa ri ${ }^{3}$ nâ heni ikạ-ara bòe-n tè tia-n bai-lafo ri ${ }^{3}$ nâ-na ${ }^{4}$.

Dè neu hate-matạ na bòe-ò doá-a ana tao ofa tane-a dè momòlo nalulutụ ana dè ana la neni ao-n nalai ela bai-lafọ bonu-bonu nème na.

Mabuị dè bai-lafọ minu nabète òe saka-saka ana mate, besạ-é ana relu nita ea esa bonu-bonu nesị bai-na na. Bòe-ma lafo-a nalò ea-a nae: "ò tia ea-kò-n, madale-lusi dei ma matei-suta

1 Bati neu dua-s, meer gewoon en juister is: neu dua, in tweeën, in twee deelen verdeelen; bij bati neu dua-s moet gedacht zijn aan: verdeelen onder hen beiden, hoewel de constructie met neu moeielijk deze beteekenis hebben kan.

2 Mananapalu, bedoeld is nananapalu.

$3 \mathrm{Ri}=$ Term. nd ̀̀.

4 Nâ-na=Term. nä̈-n (ana). 
dei fò fali-oli-kau dei ma toä-tasi-kau dei, tè ta-a na neu ma mai-ò mate-ò oli dale ma mòpo-ò tasi dale.»

Bòe-ma ea-a neu dè fua-ná lafo-a neu karou-na dè no-n ana lèo madạ lain neu.

Dè dua-s belaö rarò ', basa na fò ea-a fua-fua nò bai-lafọ tè bai-lafọ bòe-ò tutura bai-bai-ana nò ea-a karou-na dè toï adi laka-dui-na losa dodòle-na neu dè nâ heni ea-a dodòle-na. Hu na dè losa besạ ia, au hule nò horomata, bulụ-a tia-lai manalès tutuị ia hapu lelạ na mamula matabebesa sudi maneni ea-a laka-dui-na, madodòlẹ dò dodòle-n ta-a? Tuka au hahapu-ka na tèbe-tèbe ea-a dodòle-n ta-a. Sama lèo bisi-nạ́-a tutuị-a, lafo-a tutura bai-bai-ana nò ea-a karou-na dè toï laka-dui-na losa lèo dodòle-na neu, a na ea-a namedạ-hedis-a, bòe-ma ea-a nakaroroti ma nae: "auwí, auwí, ubea tao karou-ka dè ri-na 2 lèolèo hedis-a?» Bòe-ma lafo-a lai-lai dè ana sipo ma nae: "manenète, tia, tè au afakète ahère, hu au bi nafa mapena-ina-ara tòö heni kau-a».

Nò tataos matạ na losa dua-s bei losa tasi-sụ́-a, bòe ma lafo-a palaboku $^{3}$ nò dale namahòö padoạ nala madạ lain. Neu hatematạ na * bòe-ò lafo-a ana hule ea-a nae: "mai dua-kita tarò madạ lain lèo nò-hụ́-ara teu fò dua-kita seu nò-boa nurạ!»

Dè ea-a-ò ana tuka tia-n bai-lafọ hihí-na bòe, dè dua-s reu dè ralaka tino nò-hụ esa.

Bei dua-s losa nò-a hu-na bòe ma lafo-a nafada neu ea-a nae: "mahani nò-a hu-na, tia, fò ela au raba lèo lain u seu nò-boa nurạ, fò dua-kita tâ isi-na ma tinu òe-na fò tatè tala las-ara ma tasufu tala ma-madạ-ara».

Bòe-ma ea-a natá nae: "malòle-a, tia!» Dè lafo-a raba lèo nò lain neu dè ana seu nò-boa nurạ. Maneni-ma ana seu nala nò-boak esa na nâ heni isi-na ma ana lokopiro rou-na lèo dae mai narará nò ea-a eni-na, fò tète ea-a eni-ina-na, na narú-lain: bom! Na ea-a ana dola: "auwí, nò-boạ-a napesi namate kau!» Maneni-ma lèo-ná na lafo-a nafada: "hu ubea dè ò lèo na mu,

1 Rarò $=$ Term. lakand $\dot{o}$.

2 Ri-na=Term. ndè-na.

3 Denkelijk zal dit woord wel evenals in Ti, en ook in Oepao: paraboku moeten luiden.

${ }^{4}$ Het voordurend gebruik van $\mathrm{na}$, (evenals te voren in de Ringgousche vertaling II), is niet bepaald verkeerd, doch wijst op invloed van het dialect van $\mathrm{Ti}$ op de schrijvers. 
tia? Malòle lenạ marali mai ia dei!» Maneni-ma ea-a narali lèo mamanạ fò lafo-a natudu-a neu na lafo-a lai-lai fò seu selụ nòboạ narará nò mamana-na bali, fò nâ heni isi-na ma ana lokopiro nò-a rou-na lèo dae mai bali fò tète lolòlo ea-a eni-ina-na bali, na narú-lain bali: bam! $\mathrm{Na}$ ea-a ana dola bali: "auwí, nò-boạ napesi namate kau bali!»

Na lafo-a nafada lai-lai bali: "ria bali na ò sala heheli-m bòe, tia, hu ta marali lèo mamanạ fò au atudu kò-a mu fa».

Dè lafo-a ana tao ea-a lèo-lèo-ná bulụ mae lai bau-bea, losa ea-a namanasa dè ta nò hara-dasị esa nò lafo-a bòe-n tè ana fali rò-rò lèo tasi-sứ-a neu nò dale-hedị; mabuị besạ-é lafo-a ana onda lèo dae mai dè ana saka mamana fufunị fò ana lèo nahani na. Lèo bisi-nạ́-a tui-rafada-a na ea-a ana fali lèo tasisứ-a neu-a, bòe-ma naneta nò mèo esa dè dua-s dea-dea fadafada (bedea befada). Bòe-ma ea-a ana tui mèo-a lafo-a hada-na ma ria dale-hedi-na.

Bei mèo-a namanène nala ea-a dedea-totoä-na ma tatao-na hu lafo-a rolu-hada-na bòe ma mèo-a bòe-ò dale-na hedis-a dè nò ea-a esa holu nala esa dè dua-s-ara bolu beseeëdu.

Basa na bòe ma ea-a nò mèo-a dua-s dadi reu tia-lai malòle dè dua-s lèo mèo-a uma-n reu dè ea-a lèo nò mèo-a nala dò-a, losa-kò dua-s-ara esa nasida nò esa, dè ea-a ana fali lèo tasi dale neu-n. Dè lèo mae dua-s esa laö ela esa lèo-ná-ò, ea-a lèo madạ lain mai fò dadama tia-na, a na ta nò namaetu-n narò ' ${ }^{\prime}$ basa sira dua-s fai masoda-na.

Neu fạ̣ na lahenda matia-lai kaduạ sira rasida dè esa laö ela esa-a ri bea ${ }^{2}$, na ${ }^{3}$ ea-a olu nala papake-na (rou-na) dè ana fè-n neu mèo-a, ma mèo-a olu nala papake-na (rou-na) dè ana fè-n neu ea-a.

Basa na bòe ma dua-s rahelu renị susupạ ma sosọ bela-bela ma rae uni sira dua-s hehelu-n ma dedea-nafada-n dò rolu-daletia-lai-na mèpe-na losa dodò-na neu ta bòle etu-n fa-a lèo-bea, na ${ }^{3}$ mèo-a mumusu-na nò bisi-nạ́-a ${ }^{+}$lafo-a-ò ela mèpe-na losa dodò-na neu-a lèo-ná bòe, fò lafo-a nò tititi-nonosi-n dadi reu mèo-a naná-n.

1 Hier is narò $=$ Term. nand $\dot{d}$.

2 Ri bea $=$ Term. ndè bè.

$3 \mathrm{Na}=\mathrm{a}$ na.

4 In tegenstelling tot het Term. acquivalent nakas-a staat bisi-ná hier, evenals boven in sama lèo bisi-ná-a tutuị-a (ook in de constructie lèo bisi-ná-a tui rafada-a) vóór het bepaalde substantief. 


\section{Rará-na.}

a. Dolu lèo èke Sina-a natudu tasi dema-n, kafa lèo riti Oli-a nafada meti naru-n; tè hu dalẹ lèo lahenda-a, fò dalẹ lèo Duaòle, teị lèo andi-ana-a, fò teị, lèo Betu-fora; dalẹ bea bubulụ, fò bulụ Dua-òle dale-n, tẹ̣ bea dadaka, fò daka Betu-fora tei-n? Hu na dè bòso matia-lai Dua-òle ma bòso maaä-fadi Betu-fora, tè faị nesị mabui-n ma lèdọ nesị mahito-n tè matundu batu tuë fò tuë-tuë mò tei-m ma masaleu ai sale fò salesale mò dale-m.

b. Matia-lai mò ai na luli baladodoi na na ai nâ-kò, maaäfadi mò besi na hedi bau-iïna na na besi hina-kò.

c. Maaä-fadi Sera tè Sera tou dale lusi, fò dale lusi patola na manapuli dale-sala; matia-lai Dai, tè Dai tate tei-suta, fò tei suta rè-rè na mamòdo tei-siko.

\section{De reiger en de rat, (door E. Fakie). \\ De reiger en de rat.}

De verhaler spreekt. Een reiger was bevriend met eene rat. Op een dag gingen de beide vrienden scheep op een visschersvạartuig van modder en gingen visschen.

En de reiger in den voorsteven was belast met het looden en de rat in den achtersteven was roergangster, en de twee vrienden vischten met vreugde.

En zoo ging alles goed, maar als zij een visch gevangen en in het vaartuig gebracht hadden, ontdeed de rad dien van het vel en at het vleesch op, dan bedekte zij de graten weer met het vel.

En de rat at zoo maar steeds de visschen op, tot zij en haar vriend ophielden met visschen. Daarna, toen de reiger zag, dat het vaartuig vol visch was, zeide hij tot de rat: "wij moesten maar naar huis terugkeeren, vriendin, want ons vaartuig is vol visch». En de rat sprak: "het is goed, vriend!»

Toen nam de reiger de visschen op om ze te verdeelen, maar zoodra hij ze opnam, zag hij, dat er niet één visch met vleesch was, maar alles slechts graten waren, bedekt met vischvel. Toen vroeg de reiger op vriendelijken toon aan de rat: "vriendin, waar is het vleesch van al die visschen gebleven?» En de rat antwoordde toornig: "ik weet daar niets van ' en

1 Letterlijk: ik weet niet tot daartoe. Dl. 68 . 
gij weet best, dat $\mathrm{ik}$ aan het roer zat en niet de bewaakster der visschen was».

Toen werd de reiger al toorniger omdat hij wist, dat er niemand anders kon zijn, die de visschen opgegeten had, dan de rat.

En op hetzelfde oogenblik begon de reiger het vaartuig van modder te bewerken en trapte het uiteen, toen vloog hij op en liet de rat daar dobberend achter.

Daarna, toen de rat overvloedig water ingekregen had en op het punt was van omkomen, zag zij eene schildpad daar in de nabijheid ${ }^{1}$ dobberen. En zij riep haar aan en zeide: " 0 vriendin, heb medelijden en wees barmhartig, ${ }^{2}$ help mij en sta mij bij, ${ }^{3}$ want anders, zal ik, hoe 't ook ga of kome (stellig) in zee omkomen ».

Toen ging de schilpad naar de rat toe, nam haar op den nek en voerde haar mede naar het droge.

En beiden gingen rechtstreeks daarheen; daarop, terwijl de schilpad de rat droeg, knaagde ${ }^{+}$deze zachtjes aan in den nek van de schilpad en boorde haar hersenpan stuk tot aan hare hersens en at die op. Daarom is het, dat tot op heden (de schildpad geen hersens heeft); ik verzoek eerbiedig, dat, indien een vriend, die dit verhaal leest, er de gelegenheid toe heeft, hij eens nauwkeurig de hersenpan van eene schilpad onderzoekt, of daar hersens in zijn of niet. Volgens mijne bevinding heeft de schildpad werkelijk geen hersens. Gelijk zooeven verhaald is, knaagde de rat zachtjes aan in den nek van de schildpad en doorboorde haar hersenpan tot aan hare hersens; toen deze de pijn voelde, sprak zij voor zich heen: "au, au, wat is er toch met mijn nek, dat het is alsof hij pijn doet?

En de rat antwoordde snel: "verdraag het, vriendin, de reden is, dat ik mij stevig vasthoud, omdat $\mathrm{ik}$ bang ben, dat de hevig schuimende golven mij zullen wegslaan».

1 Nesi bai-na na (= Term. nesik bä̈-ana-n(a) ndia), niet bai-ná $\mathrm{na}$, gelijk verkeerdelijk in het $\mathrm{Wdb}$. staat.

2 Letterlijk: heb een hart als fluweel en een buik (of ingewanden) als zijde; uitdrukkingen uit de dichtertaal.

$3 \mathrm{Oli}$, riviermonding, heeft hier vanwege het parallellisme, (evenzoo hierouder in mata-oli-dale, mò po tasi dale) zoo ongeveer dezelfde beteekenis als tasi, zee, letterlijk dus: help mij in den stroom en stut mij in zee. De samenstellingen toä-tasi, fali-oli behooren ook op zichzelf alleen tot de dichtertaal.

4 Tutura bai-bai-ana nò, de constructie met nò hier, zoo ook beneden, wegens bai-bai-ana als herhaalde vorm van bai-ana. 
Zoodoende bereikten zij de kust; daar gekomen sprong de rat met groote vreugde op het droge. Op dat oogenblik verzocht zij de schildpad: "laten wij het land ingaan naar de klapperboomen en jonge klappers plukken!»

En de schildpad volgde den wensch van hare vriendin de rat op en beiden begaven zich in de richting van een klapperboom.

Zoodra zij dien bereikt hadden, zeide de rat tot de schildpad: «blijf gij, vriendin, onderaan den boom wachten, dan zal ik naar boven klimmen om jonge klappers te plukken, opdat wij het vleesch eten en het vocht drinken om onzen honger te stillen en onzen dorst te lesschen.

De schildpad antwoordde: "het is goed, vriendin!» De rat klom in den klapperboom en plukte jonge klappers. Als zij er een geplukt had, at zij het vleesch daarvan op, en wierp dan den dop naar beneden in de richting van den rug van de schildpad, zoodat die juist met het geluid «bam» op haar neerkwam. Toen schreeuwde de schildpad: "au, daar valt een klapper op mij, zoodat ik (bijna) dood ben» ${ }^{1}$. Alsdan zeide de rat: "waarom zijt gij ook daarheen gegaan. Vriendin, gij moest u maar hierheen verplaatsen.» Als de schildpad zich verplaatst had naar de plaats, welke de rat haar had aangewezen, dan plukte de rat fluks weer een klapper in de richting van die plaats, om als zij 't vleesch gegeten had, den dop neer te werpen, zoodat die juist weer den rug van de schildpad met het geluid "bam» trof. Alsdan schreeuwde de schildpad weder: "au, de klapper valt weer op mij, zoodat ik (bijna) dood ben.» En de rat sprak wederom: "dat is nogmaals uw eigen schuld, vriendin, omdat gij $\mathrm{u}$ niet verplaatst hebt naar de plaats, die ik u aangewezen heb.»

En de rat behandelde de schildpad op die wijze wie weet hoevele malen, totdat zij boos werd en zonder een woord tot de rat te richten, rechtstreeks met droefheid in het hart naar den zeekant terugkeerde; toen pas daalde de rat af en zocht eene schuilplaats om daar te blijven. Gelijk zooeven verhaald is, keerde de schildpad terug naar den zeekant. en zij ontmoette eene kat en beiden spraken met elkander 'en de schildpad vertelde aan de kat, hoe de rat zich gedragen had en sprak van hare droefheid.

1 Napesi namate-kau = Term. napesi nakamate au, (het voorbeeld in het Wdb. sub napesi zóó te lezen). 
Toen de kat het verhaal vernomen had van de wederwaardigheden van de schildpad wegens de geaardheid van de rat, werd ook de kat aangedaan, en zij en de schildpad omhelsden elkander en beiden weenden snikkend.

Daarna werden de schildpad en de kat goede vriendinnen en beiden gingen naar het huis van de kat, en de schildpad verbleef daar; na langen tijd pas scheidden zij en keerde de schildpad naar zee terug. En hoewel zij scheidden, kwam de schildpad hare vriendin herhaaldelijk aan land bezoeken en dat geschiedde onafgebroken, zoolang zij leefden.

Op den dag, dat de twee vriendinnen scheidden en elkander verlieten, ontdeed de schildpad zich van haar kleed (huid) en begiftigde daarmede de kat en de kat ontdeed zich van haar kleed (huid) en begiftigde daarmede de schildpad. Daarna beloofden zij elkander van weerskanten onder eede, dat hun verdrag en woord en vriendschappelijke gezindheid voor altoos vast zouden zijn, zonder op eenigerlei wijze verbroken te kunnen worden; voorts dat de vijandschap van de kat met genoemde rat eveneens altijddurend zou zijn, zoodat de rat met hare nakomelingen aan de kat tot voedsel zoude strekken.

De toepassing er van.

a. Eene vischlijn als van Chineesch lood wijst de diepte der zee aan; metaaldraad als van Japansch ${ }^{1}$ koper deelt mede de lengte van het strand, dat bij vloed onderloopt; maar wat het hart der menschen betreft, als het hart van Doea-òle ${ }^{2}$, of wat het binnenste (let den buik) der menschen ${ }^{3}$ betreft, als het binnenste van Betoe-fora ${ }^{2}$, welk hart is wetend, dat het 't hart van Doea-òle weet, of welk binnenste is, kennend, dat het

1 Over Oli tegenover Sina, zie boven.

2 Zulke eigennamen in gedichten zullen oorspronkelijk wel eene toepasselijke beteekenis gehad hebben, welke thans evenwel niet meer bekend is; het blïft ook altijd de vraag, of zij juist overgeleverd zijn. Betu. komt in de tegenwoordige taal alleen voor als nakabetu, het is buigzaam; ook: het is ingebogen, krom; fola, fora beteekent „slijpen", men zegt bijv. a na fola-ná nisi-n-a la lakabetu, hij slijpt zijne tanden zóo, dat zij ingebogen zijn; voor de tegenwoordige taal wekt betu-fora het denkbeeld op van: krom ingebogen door slijpen. Òle komt alleen voor als naòle, hij trekt uit, de verbinding dua-òle heeft dus, althans voor de tegenwoordige taal, geen beteekenis.

s De alleen tot de dichtertaal behoorende woorden andi-ana, (Term. kania na), da daka, (Term. da danga ?) zijn vertaald naar de daarvoor opgegeven, door mij niet nader te controleeren beteekenissen. 
het binnenste van Betoe-fora kent? Derhalve maak Doea-òle niet tot uw vriend en Betoe-fora niet tot uw broeder, want in lateren tijd en verdere dagen, zult gij $\mathrm{u}$ stooten tegen den steen van het berouw, zoodat gij in uw binnenste vol berouw zijt, en gij zult aanloopen tegen het hout der wroeging, zoodat gij in uw hart vol wroeging zijt.

$b$. Als gij bevriend zijt met het vuur, dan is dat ten sterkste verboden ', (pemali), want het vuur zal u verteeren; zoo gij bevriend zijt met het ijzer, dan zal dat zeer smartelijk zijn, want het ijzer zal u wonden.

c. Neem Sera ${ }^{2}$ tot broeder, want hij is een man met een hart, zacht als fluweel ${ }^{3}$, want fluweel als patola-stof is wat leed geneest; neem Dai ${ }^{2}$ tot vriend, want hij is een jongeling met een gemoed als zijde, want zeer zachte zijde is wat smart heelt.

\section{Tutui Kalasi.}

Dasi ratutuda ma beka rafafada uni nai fai ulụ-a toụ esa nade Dupe-lopa. Toụ na ana-n dua, ulụ-a nade Seku-òe ma murị-a nade Kalasi. Ana manade Kalasi-a ta nau tao tataos esa bòe, hi kada naná-nininụ ma susukụ-a mesạ-ana. Maneni-kò ina-ama-n surakạ ana saka liü-n na nae: "au ta òse!» Ma maneni-kò liü-n bali, na ta holu-ei nalelạ fa, tè nalai lèo nura dale neu. Fò lelèdọ na neu leạ-ara dalẹ suku ma hatụ na neu namanaö aiboạ, banda, manu dò sudi ubea-a nai lahenda tine-osi-ñ dò nai lahenda uma-lò-n fò nâ ninu; maneni-kò ta ara laë hata fò kène nala-s, fò ela nâ ninu dò ta-a na asa neu nanà-nininụ fa ri bea ${ }^{4}$ na dei besa-kò fali lèo uma-na neu. Ama-n namanasa ma mae nala-n manaselị hu nita ana-na lelèo-lalaö ma nonoitatao lèo-ná-na ta oru dò ta hai. Hu dèke ria dè uni mai fạ̣ esa bòe ma nae sao-na nae: "bó ina-ò-nè, ò Masihète-é, malòle lenạ au adu ahí Kalasi neu manu-puị, tè anạ mata lèo-iạ-a ta soa-rá hata esa bòe.» Bòe-ma sao-na nae: "au aäfi-ka-ò lèo-ria

${ }^{1} \mathrm{Luli}$ en hedi hebben hier verbale waarde, al komen zij ook als zoodanig in de gewone taal niet voor; baladodoi, bau-iïna zijn causatieve, bijwijze van adverbium dienstdoende vormen.

2 Omtrent de namen Sera en Dai kan ik alleen zeggen dat Dain in de dichtertaal als synoniem van Selan, Seran = Ceram voorkomt, van welk eiland de Rottineezen afkomstig zouden zijn.

${ }^{3} \mathrm{Lusi}$, fluweel, is in het Wdb. overgeslagen.

$4 \mathrm{Ri}$ be $\mathrm{a}=$ Term. ndè bè. 
bòe, fò anạ ia hada-na tadalu ná-n manaselị. Faị esa bei Kalasi-a suku namanè bòe ma ama-n adu nahí-n, tuka ria malela balemata-na, neu manu-puị. Malua bòe ma Kalasi foa tè dadi neu manu-puị sò dè neu nakí nò manu-puị matạ ria-a, fò la nala i, nala ona, nala dulu, nala muri; bai saẹ nai ia, bai saẹ nai na.

Maè Kalasi dadi neu manu-puị lèo-ria fò ta dedeạ nalelạ ma ta natiạ nò lahenda sò tè nabua nò manu-puị fò lèo ria-a, fò ina-ama-n-ò sira tè toranò-aä-fadị-ò sira, tè hu ta nafarène heni ina-ama-n ma toranò-na nade-na fa, fò uni fai bea nafarènelòlo-s na nakoü dò nalò-s nae Dupe-lopa-é kung, Masihète-é kung, Seku-òe-é kung! Lèo-lèọ-a-ria. Uni ta neu-neu fò nae "kung» dò "ung» fa, tè hu bei saka nafada hata tè ta dedeạ nalelą asa fa.

Tuka manò-tutuị-a tutui dò nafada-na na nae: hu Kalasi-a nakoü dò nalò lèo-ná dè basa nonò-n-ara tuka dò nana rae lèo-ria, ma hu ria nade-na dè basa manu-puị lèo ria-a ranade Kalasi. Tèbe-tèbe lèo-ria.

\section{Verhaal van Kalasi, (door J. A. Thei).}

Er wordt verhaald ${ }^{1}$, dat er voorheen een man was, Doepelopa geheeten. Die man had twee kinderen, de oudste heette Seku-òe, de jongste Kalasi. De jongen, die den naam droeg van Kalasi, wilde niets uitvoeren; hij hield slechts van eten en drinken en slapen. Als zijne ouders hem berispten en wilden slaan, zeide hij: "ik geef er niet om». En als zij hem dan sloegen, dan wist hij niet van vergiffenis vragen, maar liep weg naar het bosch. Overdag ging hij dan in de grotten slapen en 's nachts ging hij vruchten, kippen en andere dieren en allerlei dingen uit de tuinen en huizen van (andere) menschen stelen, om daarvan te leven; eerst als hij niets vond om weg te nemen, om het te eten of te drinken of anders om er spijs en drank voor te koopen, keerde hij naar huis terug. Zijn vader was boos en schaamde zich zeer, toen hij zag, dat de zoodanige levenswijze en zulke gedragingen van zijn zoon niet verminderden of ophielden. Daarom sprak hij, naar men zegt, op een dag tot

\footnotetext{
1 Letterlijk: een woord, dat zij laten (of: men laat) vallen en eene tijding, gerucht, welke zij mededeelen (of: men mededeelt), in het Term. zou het moeten luiden: dasi-ratutudak (of: dasik ratutudak) ma bengarafafadak (bengak rafafadak); in gedichten kan evenwel dezelfde vorm als in het Ringgousch voorkomen.
} 
zijne vrouw: "moeder, Masi-hète, ik moest Kalasi maar tot een vogel maken, want zulk een knaap deugt tot niets». En zijne vrouw zeide: "ik denk er ook zoo over, want deze knaap gedraagt zich steeds zeer slecht». Op een tijd dat Kalasi nog vast sliep, maakte zijn vader, door zijne tooverkunst, hem tot een vogel. Toen de dag aanbrak en Kalasi wakker werd, was hij een vogel geworden en voegde zich bij vogels van diezelfde soort om naar het noorden, zuiden, oosten en westen te vliegen, en nu eens hier dan daar te gaan zitten.

Hoewel hij zoo een vogel geworden was, zoodat hij niet meer spreken ${ }^{1}$ kon en zich niet tot de menschen gezelde, maar zich vereenigde met vogels als hij, zoodat die hem als ouders of broeders en zusters waren, vergat hij toch niet den naam van zijne ouders en van zijn broeder, zoodat op den tijd dat hij aan hen denkt, hij geluid geeft en hen roept: Doepe-lopa koeng! Masi-hète koeng! Sekoe-oè koeng! En zoo steeds door. Men zegt dat hij maar niet zoo maar "koeng» of "oeng» zegt, maar omdat hij iets zeggen wil, maar het niet uitspreken kan.

De verhaler verklaart volgens zijn verhaal: omdat Kalasi dat geluid maakt of zoo roept volgen hem al zijne makkers en doen hem na om dat te zeggen en wegens zijn naam dragen alle vogels als hij den naam: Kalasi, (soort duif). Zoo is 't waarlijk.

(Vgl. No. 5 der Rott. Verhalen van Fanggidaej, (7 de Volgr., dl. 4 dezer Bijdr.), en $\mathrm{N}^{\circ}$. 56 der Teksten).

$$
\text { Koạ-a nò tain aụ-a. }
$$

Koạ esa nò tainaụ esa ratiạ. Dè neu lèlẹ esa dò tèpọ esa bòe ma dua-s rahehè ạ̣ fò rataba-ẹ sadi-kò-ma bea ria-na ${ }^{2}$ natepa bea ei-n. Koạ-a nae: "ò ei lutu-m ria au tabu-n na lai-esạ ana.» Ma tainaụ-a nae: "mae ò ei-ma bau-inạ-a lai sanahulu-ò au tabu-n na tepa bati-n neụ ${ }^{3}$ dua.» Bòe-ma koạ-a

1 Dedea in R. = Term. kokolak, ook verbaal.

$2 \mathrm{Ria-na}=$ Term. ndè-na als dit, ofschoon zeldzamer, in plaats van ndè gebezigd wordt.

3 In dit stuk, waarin bij uitzondering de ingeslokte medeklinker, wanr deze aan het slot van een woord voorkomt, nauwkeurig was angegeven, wordt steeds de vorm ne $\mathrm{u}$ gebezigd, als het meer de waarde van eene praepositie heeft en vóór het woord staat, waarop het betrekking heeft. Ofschoon het Term. in dit geval eenvoudig den gewonen vorm neu gebruikt, en zoo ook, voor zooverre mij bekend, de overige dialecten, zelfs gewoonlijk dat van Ringgou, is het toch zeer waarschijnlijk, dat deze schrijfwijze het ge- 
namanasa dè nae: "hohòe, ò toụ na mai tabu matepa au ei-ka dei!» Ma tainaụ-a nae: hohòe, ò toụ bòe na mai tabu maulụ!» Dè lò ei-na neu. Dè koạ-a tabu pòö-pòö-ò ta natepa tainaụ-a ei-na fa; na tè tainaụ-a nafaroròe nala batu-anạ esa sò, bòe-ma tainaụ-a nae: "ò tabu doạ sò dè au tabu bali.» A dè koạ-a lò ei-na neu bòe ma tainaụ-a tutu nenị batu-a dè tepa heni koạ-a ei-na neụ dua. Bòe-ma koạ-a lèon dè nalai dè la-la ma ei-na lòde-lòde, neụ bea neụ bea-ò ta bòle saẹ fa, dè la narò lèo lalai neu fò totofạ saka lada-losi ${ }^{1}$. A dè la-la neu ma losa Bula-kai uma-n ma Lèdo-hòro lò-n dè neu holu-ei Bulan ma Lèdo, dè selu dasi-na neu ma lòle hara-na neu nò pinu-idu, fò pinu nèmẹ-nèmẹ idu-n ma lu nèmẹ-nèmẹ mata-n, fò haradoi ma kurudò, ma nae: Bula-kai matei-telụ ma Lèdo-hòro madaleduạ, masuru kau dò mahapạ-má kau neụ ${ }^{2}$ sao loa-ma dò mafo naru-ma dei, tè au ise ${ }^{3}$-ana-mạ́ ma manatoä-manatạ́!» A dè tèbe lèọ-ria fò Bula-kai madale-sue ma Lèdo-hòro matei-lai dè nasuru-ná-n neụ sao loa-n ma nahapạ-ná-n neụ mafo naru-na, dè tusi nenị lela-lèo ma fenu nenị rolu-iku losa tèfe duị-ara tama ma etu ua-alụ-ara tesa, dè uạ falị neụ uạ ma nalẹ tulẹ neụ nalẹ. Dè manalẹ-a bòe, ma mauạ-a bòe. A dè koạ-a falị maị ${ }^{4}$ dae-bafọ nò sodạ ma tulẹ mạ̣ batu-poị nò mòle. Dè dale-n nafarerènẹ fò rène ta nafarène heni rène-n, ma tei-n namemedạ fò meda ta nameda heni meda-n. Dè hai nala Bulan-kai lèo ina bokị esa bòe ma hai-ná Lèdo-hòro lèo ama laẹ esa bòe, basa bali lèo manaadu esa bòe fò lèo manasura esa bòe. Hu ria-na dè sudi-sudi silụ mạ̣ dulu dò huä mạ̣ laka na lòle dasina neu ma selu hara-na neu, fò lèo sorụ ina-n na nan, fò sipọ manaadu na nan. Ma uni lèo fai neụ tesa muri ma lèdo neụ tama iö, na koa dau-dau bali fò lòle lèo nateạ ama-n na nan dò nafuli manasura na nan. Hu ria-na dè dadi neụ nasalèọ, fò beka ratutuda ma dasi rafafada rae: koạ dau-dau saka Lèdo-a toda ma ue ni-ni saka Bulạ-a mori beụ.

bruik in een of ander gedeelte, waar het dialect van R. gesproken wordt, juist weergeeft; eene dergelijke onderscheiding ligł toch geheel in de lijn van het Rottineesch.

1 In het oorspronkelijke lada-losi, wel een vergissing, dewijl het eerste woord buiten samenstelling la da luidt, elders is de vorm la da-losi.

? In het Term. zou hier de eerste pers. enkelvoud $u$ moeten gebezigd worden, denkelijk is neu dus onveranderlijk.

${ }^{3}$ In het oorspronkelijke is ê-an a-má, vgl. boven lada-losi.

$4 \mathrm{Mai}$ hier in plaats van $\mathrm{mai}$, in hetzelfde geval als neu voor neu. 
De koak (soort vogel, in het Maleisch van Koepang ook: boeroeng siang of morgenvogel genoemd) en de tainaük, (een klein soort vogeltje), door J. W. Toepoe.

Een koak en een taina ük waren bevriend. Op zekeren keer $^{1}$ en op zekeren tijd daagden zij elkander uit om elkander op de pooten te trappen, of de een misschien de pooten van den ander zou kunnen breken. De koak sprak: "als ik op die dunne pooten van u trap, dan is het in eens (gedaan). En de ta ina ük zeide: "al zijn uwe pooten ook tienmaal zoo groot, als ik er op trap, zullen zij in tweeën breken.» Toen werd de koak boos en zeide: "vooruit als gij een man zijt ( $=$ als gij durft), kom dan en trap mijne pooten stuk!» En de taina ük sprak: "welaan, als ook gij durft, kom dan en trap het eerst! En hij strekte zijne pooten uit. En of de koak ook al herhaaldelijk trapte, hij kon de pooten van de taina ük niet breken, maar deze had rondgegrabbeld en een steentje gevonden en sprak nu: "gij hebt te vergeefs getrapt, nu zal ik op mijne beurt trappen.» En de koak strekte zijne pooten uit en de taina ük sloeg met het steentje, en de pooten van de koak braken in tweeën. En de koak maakte zich op en vluchtte en terwijl hij vloog hingen zijne pooten er bij; waarheen hij ook ging, nergens kon hij zich zetten; en hij vloog toen rechtstreeks naar den hemel om rond te zoeken naar een heelmeester. Hij vloog al maar door en bereikte het huis van Boela-kai ${ }^{2}$, (de Maan), en de woning van Lèdo-hòro, (de Zon ${ }^{2}$ ) en omvatte hunne voeten en bracht zijn geluid uit en verhief zijne stem met snot in den neus, (z. v. a. al weenende), zoodat hem het snot al maar uit den neus en de tranen uit de oogen kwamen uit droefheid en verlangen en sprak: "Boela-kai, die zeer barmhartig en Lèdo-hòro die zeer ontfermend zijt, ${ }^{3}$ beschut mij of

1 Lèle, (lèlek) en tèpo, (tèpok) zijn geheel en al synoniem; zooveel mogelijk zijn de, in dit stuk naar de wijze der gedichten voorkomende parallelle-uitdrukkingen, ook in de vertaling weergegeven, zij het ook niet altijd letterlijk.

2 Bula-kai uit Bulan (als eigennaam nog met slot-n) en kai, wat blijkbaar het Term. kaï is, een synoniem van hòlo, hòro, beletten, verbieden, gebieden, (ofschoon dit als zelfstandig woord in het dial. van $\mathrm{R}$. ai luidt). $\mathrm{Na} \mathrm{Bulan}$ en L è do duiden deze toevoegsels dus aan: de gebieder (gebiedster).

${ }^{3}$ Mateik (lett. een buik hebbende) $=$ madalek (een hart hebbende) $=$ die barmhartig is, dus matei-telu, (drie buiken hebbende) en madale-dua, (twee harten hebbende $)=$ die zeer barmhartig is. 
geef mij eene toevlucht in uwe breede luwte en in uwe lange schaduw, want ik ben (als) een verlatene en een wees, ik ben een die kommer en gebrek lijdt. En werkelijk geschiedde het, dat Boela-kai medelijden had en Lèdo-hòro zich ontfermde en hem beschutte in hare breede luwte en hem eene toevlucht gaf in de lange schaduw, en wreven met de kennis, eigen aan het geslacht, en rechtbogen met de kunde, eigen aan het land, totdat de gebroken ${ }^{1}$ beenderen weder aaneensloten en de afgekapte spieren weder aaneen waren, zoodat het geluk terugkeerde en de fortuin terugkwam ${ }^{2}$. En dus was hij gelukkig en fortuinlijk.

Toen keerde de koak terug hier naar de aarde in gezondheid en kwam weder hier in de wereld met welzijn en zijn hart bleef indachtig, met een aandenken, dat niet vergat en zijn gemoed (letterlijk: zijn buik) bleef herinnerd met eene herinnering, die niet losliet. En hij nam (beschouwde) Boela-kai als eene moeder, die hem gebaard, en Lèdo-hòro als een vader, die hem verwekt had, en als een, die hem geschapen, en als een, die hem geformeerd had.

Daarom ${ }^{3}$ is het, dat telkens als de dageraad in het oosten komt (verschijnt) en de morgen aan het «hoofd» (van den hemel $=$ de oosterkim) komt, (zich vertoont), hij zijn geluid verheft en zijne stem uit, alsof het zijne moeder is ${ }^{4}$, die hij te gemoet gaat en of hij haar, die hem geformeerd heeft, inhaalt, en als de dag na aan het westen is en de zon de "staart" (van den hemel, de westerkim) nabij is, dan roept hij zingend of snappend, alsof het zijn vader is van wien hij afscheid neemt en of hij hem, die hem geschapen heeft, uitgeleide doet.

1 Omtrent de constructie tèfe-dui-ara (etu-ua-alu-ara) zie bij het dialect van Òepao.

2 Ua fali neu ua, (nale tule ne u nale) beteekent letterlijk: het geluk keerde terug tot het geluk, evenals beneden in: rène ta $\mathrm{n}$ a farène-heni rène-n, (meda-ta nameda-heni meda-n, letterlijk: de herinnering vergeet niet zijne herinnering (of wil men het eerste rène of meda verbaal opvatten: hij herinnert niet vergetende zijne herinnering), is het laatste gedeelte eigenlijk een zinloos toevoegsel vanwege den klinkklank; wil men er eenigen zin aan hechten, dan kan men het opvatten als versterking: het geluk kwam geheel terug, hij herinnerde het zich, zonder iets te vergeten.

${ }^{3} \mathrm{Hu}$ ria-na $=$ Term. hu ndia.

$4 \mathrm{Na}$ na-n=na na (vergl. boven pag. 32 ) = Term. ndè ndia. Of de slot $n$ hier als het bezittelijk voornw. (vgl. ook hierboven hu ria-na en op pag. 607 ria-na) moet worden beschouwd, dan wel als het overblijfsel van $\mathrm{na}$ in de functie van nadrukswijzer, is niet zoo geheel zeker; het waarschijnlijkste is het laatste. 
Daarom is het tot eene gelijkenis (spreekwijze) geworden, welke men mededeelt en vermeldt ${ }^{1}$ : de koak zingt of snapt, zoekende de zon, als zij opkomt en de moesang huilt, zoekende de maan als zij opnieuw verschijnt.

(Vgl. ook $\mathrm{N}^{\circ}$. 15 der verhalen van Fanggidaej, $7^{\text {de }}$ Volgr. dl. 4 dezer Bijdr.).

\section{Dialect van Òepao.}

Tutui eëtụ.

Toụ telu ratiạ, esa nade Taẹ-ama-n ma esa nade Fèö-ama-n ma esa nade Fèö-baï. Toụ fò nade Taẹ-ama-n, toụ ria masanasi, dè hè pinu seku-seku ma Fèö-ama-n ao-na osu-roụ ma Fèö-baï laka-polị.

Neu faị esa bòe, ma telu-s radedea ao, fò sèfe lèo tasi selị reu. A dè nò dalẹ esa dò nò hihị esa esa-esa-kò sipo nò dale katemạ dedeạ ria.

A tè Taẹ-ama-n foa napadeị dè lòle hara-dasi-na neu tia-n dua-s ma nae: "bó tia-kemi-n-ó, ita dedea-na malòle-a sò, tè emi dua-kemi hi, na mamanène au dedea-k esa ria ia: losa tasi taladạ na bòso hè pinu dò bòso aäru dò bòso tòto òe neu lakạ-arạ!» Bòe-ma Fèö-ama-n nò Fèö-baï ratá rae: malòle-a.»

Dè ara dedeạ basa bòe, ma telu-s sèfe-a serị reu. Losa tasi taladạ bòe, ma Taẹ-ama-n pinu-na lò losa bafa-na ma Fèö-ama-n ao-na naète ma Fèö-baï laka-na hana-na seli sò. Tè ala ta bòle hè pinu dò ta bòle aäru dò ta bòle tòto òe, hu rafarène Taẹama-n dedea-na.

Tè Taẹ-ama-n saka eëdị naulụ fò hè pinu-na dè nae tia-n dua-s nae: "lèo rusa esa laö nesị mata-na na au siro amate-n.» Nae lèo-ná tè Taẹ-ama-n ròse namada pinu-lòdo-na sò. Bòe-ma Fèö-ama-n tao ria nu-na neu bali de nae: "ò, lèo-ria sò na au uni tali fò fefèo neu ao-na.» Fèö-ama-n nae lèo-ria tè aäru basa ao maète-na sò. Fèö-baï nita tia-n dua-s tatao-n ria bòe, ma ria oru neu ofạ-a su-na dè rui òe neu lima-n dua-s, poä neu laka poli-na ma nae: "ria tetèbes-a.»

Tutuị ia ria ia.

1 Vgl. pag. 606. 


\section{Een kort verhaal, (door J. A. Sjioen).}

Drie mannen waren met elkander bevriend, een heette Taẹama-n, een Fèö-ama-n en een Fèö-bại. Hij, die den naam droeg van Taẹ-ama-n, was verkouden en moest steeds maar zijn neus snuiten, (lett.: het snot uitknijpen) en Fèö-ama-n had eene huidziekte (cascado) en Fèo-baï had een kaal hoofd.

Op een dag spraken zij er met elkander over om naar de andere zijde van de zee te roeien. En één van hart en één van zin stemden zij van ganscher harte met dit voorstel in.

Maar Taẹ-ama-n stond op en richtte het woord tot zijne beide makkers en sprak: "vrienden, wat wij gezegd hebben, is goed, maar als gij beiden wilt, hoort dan dit eene woord van mij: als wij in volle zee gekomen zijn, mag er geen neus gesnoten, niet gekrabd en geen water met het hoofd in aanraking gebracht worden.» En de anderen zeiden: "het is goed.»

Nadat zij zoo gesproken hadden, gingen zij met hun drieën aan het roeien naar de overzijde. Toen zij in volle zee gekomen waren, hing Taẹ-ama-n het snot tot aan zijn mond en Fèo-ama-n had jeuk aan zijn lichaam en het hoofd van Fèö-baï was erg verhit. Maar zij konden niet den neus snuiten, niet krabben of water (met het hoofd) in aanraking brengen, omdat zij indachtig waren aan hetgeen Taẹ-ama-n gezegd had.

Maar Taë-ama-n zocht het eerst een middel om zijn neus te snuiten en sprak tot zijne twee makkers: "als er eens een hert vonr ons langs ging, dan zou ik het doodschieten». Terwijl hij zoo sprak (deed hij alsof hij een geweer aanlegde en) veegde het uithangende snot "droog» (weg). En Fèö-ama-n deed ook het zijne en sprak: "o, als het zoo was, dan zou ik een touw aanhangen om daarmede het (hert) te omwinden». Terwijl hij zoo sprak, krabde hij overal zijn jeukend lichaam. Toen Fèö-baï zag, wat zijne makkers deden, schoof hij naar den rand van het vaartuig en schepte water met beide handen en stortte het (bij wijze van plechtige bevestiging) uit op zijn kaal hoofd en zeide: "zoo is het werkelijk".

\section{Dit is het verhaal.}

1 Sèfe-a, (zij) roeiden maar, deden niets dan roeien. Het dialect van Òepao makkt, evenals dat van R., veel meer gebruik van dit $a,(\mathrm{Bi}$. ka), dan het Term. 
Lain loa dae bòe, tè hu dano-ina nai lain, dè lain loa lena dae.

Dulu bau muri bòe, tè hu bubu òe nai dulu, dè dulu bau lena muri.

Ona bau i bòe, tè hu Koponi nai i, dè i bau lena ona.

Sadi masanenedạ dò sadi mafarerènẹ: rae Sela-uda-ama ei-n dò Bobano-ama lima-n, fò eị esa lalị esa dò limạ esa lòpe esa.

Bó tiạ-ara emi-n dò bó senạ-ara emi-n , rae Bulạ manaboki-siọ dò Lèdo manalae-falụ, dè sipèo kèọ mesan dò kou-ei mòdọ mesan.

Rae Bui manatiro tadụ dò Lò manamète kòrọ, tè hu koạ manatiro tadụ neu tiro tadạ fè Lò dò kia manamète kòrọ neu mète fè Bui, besak-a Lò manatiro tadụ dò Bui manamète kòrọ.

Bòso matei telu dò bòso madale dua, tè sadi madale-dano, dò sadi matei-meti, fò ela pòko-dano rèmẹ dalẹ dò kake-meti rèmẹ dalẹ.

Meu lòö mala bau Koli ${ }^{1}$ dò tati mala tui Sina, fò rae neu balụ lain dò fua neu tonạ lain, fò meni mai Penapua dè meni mai Menggilama, ${ }^{2}$ fò tare tui neu dano, fò ela tui naseka dano dò sèle bau neu lè, fò ela bau naròro lè.

Lesị-ara rae lèo-ná dè Òe-tè rae lèo-ná ma Lenạ-ara rae lèo-ná dè Pila-pisa rae lèo-ná.

Tè hu fạ̣ esa nai ria dò lèdọ esa nai ria, Lòpo-sepa lèo meda dò Bạo-bèle lèo ade, dè ade mabua besi dò meda matanòe lilo.

Bó tiạ-ara emi-n dò bó senạ-ara emi-n, rae Lusi-lepa lèo tua , dè tua manalepa lèo, fò basa falu-ina ai-n dò basa ana-mạ́ ain

Sadi tasanenedạ dò sadi tafarerènẹ: tuü heni pila rara-t-ara dò kari heni kèo apa-t-ara dò tuü heni naka tua-t-ara dò kari heni tèno dae-t-ara, fò teu tuka taruü-n dò usi talosa-n.

1 De vorm Koli is hier overgenomen uit het dial. van Baă, in dat van Òe-pao moet de naam Oli luiden.

? Zuiver Ò-paosch: Mekilama. 
Mai tasanenedạ dò mai tafarerènẹ, fò teu tai tuka Lae-Mae dò teu tabu tuka Suta-lane, fò ela teu tita loa masodạ dò tita lutu mamòlẹ-ara.

Tè hu faị esa nai ria dò lèdọ esa nai ria, reu toli òe rasamao-n dò fufua dae raboi-n, dè dò-na laifata dò hu-na eroaka, tè hu reu ali-sụ ana bali dò fau-foi heni-n bali, losa fạ dò lèdọ ia.

Sadi masanenedạ dò sadi mafarerènẹ tia-ikụ-ara emi-n dò sena-lèo-ara emi-n, bòso mesị Lèfe-malèo ai-n, tè fa-kò ai-a nalèo heni kemi, dò boso mesị Totò-matahí batu-n, tè fa-kò batu-a natahí heni kemi.

Ama-n Lòe-lepa lutu-na dò tòö-n Talu-nale dea-na rae dea ei manalẹ dò lutu lima mauạ, tè hu neu fui Lepa-lèdo dò neu sòko Nale-bulan fò ela tei nò tepa dò feò-fide nò lada.

Bó tiạ-ara emi-n dò bó senạ-ara emi-n, mai foa-fanu mapadeị dò afe-lèlo matụ dai fai-ra dei dò dai lèdo-ra dei, fò hule neu Bulan dò malò neu Lèdo, fò ela dula-dalẹ-ara mai dò leü-teị-ara mai fò tama dale-m-ara dei dò tesa tei-m-ara dei.

Bea ria losa lutu dò bea ria dai lane, fò du lane Ikufao dò losâ lutu Sarapoi.

Baị-ara peda ela dò sòrọ-ara fua ela rae: tou Dène-bú-dulu dò taë Taka-lai-laka lelète neu sao dò fifinu neu tu, dè tu nala Kona-boi Kada-lofa dò sao nala Sisolu Ati-besin, dè bòki Saiama Dène-bú dò lae Soru-ama Taka-lai, besa-kò ama-n manalutụ, dè lutu-lutu tuka ama-n dè tòö-n manaheu-deạ, dè heu deạ tuka tòö-n.

Bó tiạ-ara emi-n dò bó senạ-ara emi-n, sadi masanenedạ dò mafarerènẹ tè rae: Balu-ama-n Lèë-dua dò Fèlạ-ama-n Besi-delu sala nai unu-n lain dò heta nai tadu-n lain, dè mita tè ò tè-n dò nita tafa ò tati-n, tè sadi tati matatalè-n dò tè makokòko-n hu ita tia-iku malòle-n dò ita sena-lèo mará-n Balu-ama-n Lèëdua dò Fèlạ-ama-n Besi-delu.

Bó lesị-ara emi-n dò bó manẹ-ara emi-n, tè masanenedạ bai dei dò mafarerènẹ bai dei; idu nasananadu-m-ara hae Bola-luki bòe dò rai-dò namanène-m-ara ramanène Pau-balo bòe? Tè hu Paun susura narụ dò Bola maiko-narụ, dè elus ladi Bola-luki dò tatas tè Pau-balo, na hetu lèo fai ria bòe dò lèo lèdo ria boè. 
Spreuken of spreekwijzen, (in de taal der gedichten, doch volgens het dialect van Òepao, medegedeeld door J. A. Sjioen).

Hemel en aarde (waren of zijn voor de waarneming) even ruim, maar omdat er een groot-meer (als oorsprong van de regen en vandaar van al wat goed is) in den hemel is, is de hemel ruimer dan de aarde.

Het Oosten (was of is voor de waarneming) even groot als het Westen, maar omdat in het Oosten een bron van water ontspringt ${ }^{1}$, (als zonnebeeld van leven in het water-arme Rotti), is het Oosten grooter dan het Westen.

Het Zuiden (was of is voor het gezicht) even groot als het Noorden, maar omdat de "Compagnie» in het Noorden is, is het Noorden grooter dan het Zuiden.

Herinnert $u$ of weest indachtig (daaraan, dat) men zegt: de voet van Sela-Oeda-ama ${ }^{2}$ en de arm van Bobano-ama, opdat gij eensgezind zijt, evenals voor die beiden was één voet één stap, of één arm één zwaai.

Vrienden of makkers, men zegt: Boela ${ }^{3}$ bracht negen kinderen voort, of Lèdo ${ }^{4}$ acht, maar 't was al maar zwarte hoeden, of 't was al maar gele ${ }^{4}$ kousen, (zij waren allen als Europeanen, d. w. z. goed gekleed, niettegenstaande het groote getal).

Men zegt Boei ${ }^{5}$ was iemand, die uitkeek naar kapen, of Lò iemand, die uitzag naar landpunten, maar eerst, toen de koak-

1 Bubu òe, opspuitend water; omtrent de constructie zie beneden.

${ }^{2}$ A ma zonder volgende $\mathrm{n}$ maakt bepaaldelijk deel uit van den naam; omtrent die eigennamen in de taal der gedichten, zie het boven pag. 604 opgemerkte.

3 De Rottineezen vatten Bulạ en Lèdo hier als namen van menschen op, ofschoon ook de opvatting als Maan en Zon, als godheden, mogelịk is.

"De ngele kousen" hebben hun ontstaan wel alleen aan het parallellisme te danken.

s Buik, (grondwoord: bui), beteekent: achterdeel, ook: bodem van de zee, enz.; lò beteekent: de diepe zee, (tegenover: de zee dicht bij het land); de eenige betrekking, welke deze beteekenissen op de namen zou kunnen hebben, is wel, dat zij iets aanduiden, dat zich niet verplaatsen kan. De koak en loerie worden in de gedachten steeds te zamen genoemd; eene diepere beteekenis, dan dat het wezens zijn, die zich verplaatsen kunnen, schijnt er niet achter het noemen dezer vogels te schuilen. 
vogel, die (gewend is, dat hij) uitkijkt naar landpunten, voor Lò daarnaar ging uitkijken, of de loerie, die (gewend is, dat hij) uitziet naar kapen, voor Boei daarnaar ging uitzien, (d. w. z. door de leering van hen, die meer ondervinding hebben), toen eerst werd Lò iemand, die (het verstond, dat hij) uitkeek naar kapen, of Boei die uitzag naar landpunten.

Weest niet "driebuikig» of weest niet "twee-hartig" ', (d. w. z. weest niet onstandvastig), maar hebt een hart als een meer of hebt een buik (inborst) als de ondiepe zee, opdat (uwe gedachten standvastig zijn gelijk) daarin de meer-pòko ${ }^{2}$ blijft of de zeester steeds aanwezig is.

Men zegt: Gaat heen en velt den wa roe-boom uit Koli ${ }^{3}$, of gaat heen en hakt om den toei-boom uit China, opdat gij hem plaatst op een vaartuig, of laadt op een schip, en gij hem herwaarts brengt naar Pena-poea (de kust van Baä), of hem herwaarts voert naą Menggi-lama (een dorp in Baä), opdat gij den toei-boom plant bij het meer en hij zich uitbreidt bij het meer, of giji den waroe-boom in de aarde zet bij de rivier en hij overal de rivier volgt: (z. v. a. brengt het goede van elders in uw land over).

Zij, die als Lesị ${ }^{+}$zijn, zeggen zóó en dus zeggen die als Oè-tè (ook) zoo; zij, die als Lenạ ${ }^{4}$ zijn, zeggen zoo, dus zeggen zij, die als Pila-pisa zijn (ook) zoo, (z. v. a. de kleinen volgen de grooten).

Op een of anderen dag, of op een of ander tijdstip was Lòpo-Lepa als soldeersel of Bao-bèle als houtskool, en soldeersel is het, dat het (gebroken) ijzer vereenigt, of houtskool, dat goud of zilver (om het herstellen) doet smelten, (gezegd als beeld van het vrede-stichten).

1 Anders dan boven (pag. 609) hebben natei-telu, nadei-dua hier ongunstige beteekenis.

${ }^{2} \mathrm{Pòko}$, (een soort visch, op Koepang ikan kĕbus of kabus=Mal. gabus) wordt in het dial. van $R$. tot pòö, zoo zal denkelijk de eigenlijke vorm in het dial. van Òepao ook lniden.

3 Vgl. boven pag. 554 .

4 Lesi, (de eigenlijke vorm van de $r$-dialecten is resi) is oorspronkelijk hetzelfde als lena: wat of wie meer is, nitsteekt; ook komt lesi of les i in gedichten voor naast $\mathrm{manek}$, mane vorst, de beteekenis dezer namen is hier dus wel duidelijk, daarentegen is voor òe-t ̀̀ of Pila-pis a geen passende beteekenis te vinden. 
$O$ vrienden of makkers, men zegt Lusi-lepa ${ }^{1}$ is als de lontarpalm, en de lontar-palm draagt (z. v. a. onderhoudt) de geslachten der menschen, dat zijn de weezen of verlatenen.

Laten wij ons herinneren of indachtig zijn (aan het volgende): laat ons wegwerpen onze bruine ${ }^{2}$ paarden of ons ontdoen van onze zwarte buffels; of laat ons wegwerpen het boschje van onze lontar-palmen of laten gaan het vruchtbare van onze velden,$^{3}$ (om het goede of betere) te volgen, tot wij het bereiken, of het na te jagen, tot wij het verkrijgen.

Laten wij ons herinneren of indachtig zijn, dat wij gaan vasthouden in navolging van (z. v. a. de daden volgen van) dae$\mathrm{Mae}^{*}$ of de voetstappen gaan drukken van Soeta-lane, ${ }^{+}$opdat wij komen te zien het vertrek (de plaats) van het heil of de omwalling van den vrede.

1 Hier is aan den naam wederom beteekenis toe te kennen, aangezien lusi (fluweel) gezegd wordt van het hart, als beeld van barmhartigheid, vgl. bijv. boven (pag. 605), en lepa, „dragen" overeenkomt met wat van den lontar-palm gezegd wordt. Overigens is het hier gegevene stellig onvolledig, dewijl de parallel ontbreekt.

2 Eene constructie als pila rara-t-ara, laat zich desnoods verklaren als: de bruinen onzer paarden, (evenals kèo apa-t ara, als: de zwarten onder onze buffels, en boven pag. 610 tèfe duí-ara als: de gebrokene onder de beenderen, enz.), gelijk men nu nog met de omgekeerde genitief-constructie kan zeggen, bijv. dae-a malòle-na, de goede onder de gronden, de goede grond. Maar toch is het niet waarschijnlijk, dat men bier werkelijk nog te doen heeft met een overblijfsel uit den tijd, dat elke genitief op de gewone M.P. wijze geconstruëerd werd, dan zou de genitief-betrekking wel op eene of andere wijze aangeduid zijn. Nog onwaarschijnlijker is dit, waar het geldt zulke verbaal-adjectieven als boven bubu-òe voor òe-bubu, springend water, oba-tula voor tula-obak, vgl. Teksten, pag. 617 , een gĕbangpalm, waarin men eene insnijding heeft gemaakt. Dat anderszins het Rott. een tijd zou gekend hebben, dat elk adjectief zonder meer aan het subst. voorafging, (dus niet in de waarde van een partitieven genitief), een toestand, nauwelijks voorkomende bij eene of andere geheel verloopen taal op NieuwGuinea, is ook wel niet aan te nemen. Het meest waarschijnlijk is, dat men hier met kunstmatige constructie's te doen heeft, vgl. boven pag. 553 .

${ }^{3}$ De beteekenis in het Wdb., pag. 871, aan tèno-dae toegekend, is, volgens mij gegeven จerklaring, onjuist; het is wel eenvoudig $=$ Term. dae-tènok, met de in de dichtertaal gebruikelijke constructie.

${ }^{4} \mathrm{Suta}$, (zijde), wordt evenals lusi (fluweel) gebezigd van een medelijdend hart, omtrent lane, (grens) zie beneden; in den anderen naam kan lae eene verkorting zijn van lalae, stal, dialectisch nog: heining, dus een synoniem van lutu; voor mae weet ik evenwel geen passende verklaring te rinden.

Dl. 68 , 
Op een of anderen dag nu, of op een of ander tijdstip, gingen zij het met water begieten om het te verzorgen, of zij bewerkten den grond om het op te kweeken, en het blad stond weelderig en de stam was krachtig; maar zij hebben het wederom uitgegraven, of het weder uitgetrokken, (en zoo is 't gebleven) tot op dezen dag of dit tijdstip.

Men zegt: herinnert $\mathrm{u}$ of weest (er aan) indachtig , gij vrienden van het land of gij makkers van het geslacht, gaat niet over het hout van Lèfe-malèo ${ }^{1}$, want wellicht zal het (hellende) hout $\mathrm{u}$ "wegtellen» (doen vallen), of gaat niet over den (schuinstaanden) steen van Tòto-matahi, ${ }^{1}$ want wellicht zal de steen u doen vallen, (z. v. a. vermijdt kwaad gezelschap, enz.).

De steenen (visch-)pagger van vader Lòe-lepa ${ }^{2}$, of de omrastering om visch te vangen van Taloe-nale ${ }^{2}$, noemt men eene omrastering met gelukkige "beenen" ${ }^{3}$, of een vischpagger met gelukkige armen '(zijden), maar hij offert aan Lepa-Lèdo ${ }^{4}$ (zon), of brengt offeranden aan Nale-Boelan ${ }^{4}$ (Maan), opdat daarin komen de tei-visch met den tepa-visch, (op Koepang ikan tembang), de fide (op Koepang ikan toelang-toelang) met den lada-visch.

Gij vrienden of makkers, verheft u en gaat staan, of ontwaakt en gaat zitten, vroeg of bijtijds, om te bidden tot Boelan (de Maan), of te roepen tot Lèdo (de Zon), opdat kome wat in het hart of gemoed rondgaat, ${ }^{5}$ opdat uw hart volkomen of uw gemoed volmaakt worde.

1 Het tweede gedeelte der namen, matahí. maléo staat duidelijk in verband met het volgende natahí of na lèo heni, "weghellen" van natahí, nalèo, hellen, (de beteekenis van nalèo, volgens voor mị niet nader te controleeren opgave); tòto beteekent als afzonderlijk woord: aanraken; lèfe is mij onbekend.

2 In de namen Lòe-lepa, Talu-nale, heeft lepa de beteekenis van: voorraad, z. v. a. overvloed, nale (=nalek, nalẹ) die van geluk, Lòe en Talu of Talo zijn in gewoon gebruik zijnde namen.

3 De zijden ran een vischpagger heeten limak, "armen"; de benaming "beenen" komt hier alleen voor wegens het parallellisme.

4 De vonrvoeging van Lepa en Nale voor Lèlo (Zon) en Bulan (Maan) is hier alleen maar geschied in overeenstemming met de eerste namen.

s Wat eigenlijk onder dula-dalek, (-dalẹ) en leü-teik, (-teị) moet verstaan worden, is niet volkomen duidelijk; de Christelijke Rottineezen noemen den Heiligen Geest Dula-dalek of Dula-dale-leü-teik. 
Wie kan (uit zichzelf) de omwalling ${ }^{1}$ bereiken; of wie kan komen tot de grens, zoodat hij bereikt de grens ${ }^{1}$ van Iku-fao (Ingoe-fao, in het Termanoesche), of de omwalling van Sarapoi, (Salapoi eveneens in het Termanoesche), z. v. a. wie kan uit zichzelf het heil bereiken.

De grootvaders hebben bewaard, of de voorvaders hebben nagelaten het gezegde: de man Dène-bòe-doeloe of de jongeling Taka-lai-laka ging uit om te trouwen, of ging ten huwelijk vragen, en hij huwde Kona-boi Kada-lofa, of trouwde Si-soroe Ati-besin, en zij verwekten Sai-ama Dène-bóe, of kregen tot kind Soroe-ama Taka-lai; toen was de vader iemand, die steenen vischpaggers maakte, en (de zoon) maakte steeds zulke vischpaggers in navolging van zijn vader, of zijn oom (hier alleen maar voor het parallellisme naast "vader») was iemand, die vischversperringen maakte en (de jongen) deed zoo in navolging van zijn oom.

Vrienden of makkers herinnert $u$, of denkt daaraan. Men zegt: Baloẹ-ama-n, (de vader van Baloẹ geheeten), Lèë-doea, of Felạ-ama-n, (de vader van Felạ geheeten), Besi-deloe is verkeerd op eene klip geraakt, of is op eene vooruitspringende rots blijven steken, (heeft zich aan het een of ander verkeerds schuldig gemaakt); ziet gij eene lans, steek hem daarmede en ziet gij een zwaard, sla hem daarmede, maar houw slechts kwansuis en steek slechts schijnbaar, want zij zijn onze goede vrienden van het land en onze goede makkers uit het geslacht.

Gij hoofden of vorsten herinnert $u$ een weinig of denkt een weinig daaraan! Hebben uwe ruikende neuzen wel Bola-loeki ${ }^{2}$ geroken en hebben uwe hoorende ooren wel Paoe-balo ${ }^{2}$ gehoord? Maar Paoen had een langen hoorn, of Bola had een

1 Bij lane, grenis, (vgl. ook boven), denkt men aan sodak, soda, open vlakte en ook: heil, (de bijgevoegde naam doet niets ter zake); sarapoi, salapoi is een soort versiersel $=$ bu a malòle, v. d. de omwalling van Sarapoi gelijk boven: de omwalling van het heil, van den vrede, (mam òlek, ma mòlẹ).

${ }^{2} \mathrm{Luki}$ staat, door invloed van de l-dialecten, wel voor ruki=Term. lungi in lungi-lai, walviseh, dus beteekent de naam Bola: (die zoo groot was) als een walvisch; balo in den anderen naam kan wel niets anders zijn dan het ontleende balok, balo, balk, dus: Paun, (die zoo lang was) als een balk; op eene of andere overlevering schijnt overigens niet gezinspeeld te worden. 
langen staart; toen brak de bliksem ${ }^{1}$ Bola-loeki of trof de bliksemschicht Paoe-balo, en zoo zal het ook wel gaan op dezen tijd of dit oogenblik.

\section{Dialect van Dengka, (Dengga).}

Tou mamasuị esa natalạ̣ nò tou hata-tạ́ esa. Faị esa bòe-ma tou hata-tạ́-a neu dama lai-na. Bòe-ma tou mamasuị -a dòdo-mbau dè nahao-e. Neu faị esa fai bòe ma tou mamasuï-a neu dama eni fai. Bòe-ma ana denu sao-na naädòto mbelạ tè duụ hòkọ. Bòema ana hène ume ata neu dè falo nala saka-n seli isi-na dè fè sao-na nasu, dè ana mboti lafe esa neu hinạ-a, tè ona-ná-ò lạ-a fa kòlo-kòlo lae neu dè lai-na lilinda-a. Hu ana dodò tè lai-na nita lạ-a bòe ma nae: "lai-a, au losa ume ata ma fanggi mbae-lèbe-a sia au saka-ngga dè afị mumunasa tè au hela mesạnggò mu lae, baï-n!» $\mathrm{Na}$ tè lai-na dodò sia lala-n nae: "tè ala dòdo sa dè halạ hòkọ, tè aka-a lạ-a fa ia ?» Dò-dò fa bòe ma inạ-a sòde dè mbedạ nala sia ume ata ena. Bòe-ma sao-na nòë lai-na nae: "lai-é, ume ata uma fò tâ mbelạ dei baï-n!» Feä tèndẹ bòe ma tou mamasuị-a nahine nae sisi ia ngga sisi banda afa. Dè feä ngga sulu-s tè manafalo saka-a loli neu dè mate nakandò; feä-n dei dè palisak tè saka-isi-na manafalọ ${ }^{2}$.

Een rijke man was bevriend met een arme. Op een dag ging de arme man zijn vriend bezoeken. En de rijke slachtte allerlei dieren en onthaalde hem. Op een anderen dag ging de rijke hem op zijne beurt bezoeken. Toen beval hij zijne vrouw maïs te koken, maar er was geen toespijs. En hij ging naar boven in huis en sneed het vleesch van zijne eene dij af en gaf dit aan zijne vrouw om te koken, en hij wikkelde een slimoet om de wond, maar toch bleef het bloed naar beneden droppelen, terwijl zijn vriend stond toe te zien. Omdat hij dacht, dat zijn vriend het bloed zou zien, zeide hij: "vriend, toen ik boven in huis kwam, is de steenpuist op mijne dij doorgebroken, wees dus niet boos, dat $\mathrm{ik} \mathrm{u}$ alleen beneden laat!» Zijn vriend dacht evenwel bij zich zelf: "wat wordt er toch geslacht, dat er geen

1 Elus, in de gewone taal: regenboog, staat in de gedichten steeds in verbinding met tatas, donder of bliksemschicht.

2 Manafalo in plaats van nanafalo (nenefalọ). 
geluid gehoord wordt en slechts het bloed hier maar vloeit?» $\mathrm{Na}$ een korten tijd had de vrouw opgeschept en boven in huis klaar gezet, toen riep haar man zijn vriend en sprak: "vriend, kom boven in huis en laten wij maïs eten!» Zoodra zij gezeten waren, bemerkte de rijke, dat het vleesch niet van een dier afkomstig was. En voordat zij begonnen te lepelen, rolde hij, die zijne dij afgesneden had, om 'en stierf meteen, toen zij hem onderzochten (zagen zij) pas, dat het vleesch van zijne dij afgesneden was. (Medegedeeld door H. Taka).

\section{Mezach nò Henu.}

Aäna-tou Dengga lua, esa nala-na Mezach ma nonò-na nala-na Henu. Faị esa dè aäna kaluạ na tèndẹ leu dala-ina ${ }^{1}$-a su-na dè laäminạ. Bòe-ma Henu netane ${ }^{2}$ Mezach: "feä-n-nia hò mua sa?» Mezach netá: ${ }^{2}$ "au ua sisi-mbuị mò aäu ale. Afis-a au aä-ngga Jehezkial tèë si mbuị sia mòlẹ lala dè eni nala mbui lunda esa. Wah, Henu-é, lunda na saka-na baü ona amba mòne kapai esa saka-na. Hai sefa dè tao sisi bebelạ ma hai tunu, dala, nasu bòe, sesena dè hai mia; ạ tè feä hela pala dai basa ume titiạ. Au uündandạ́ ${ }^{3}$ sia Lòte ia mbuị esa ngga baü lunda-a». Bòe-ma Henu nae: "au uündandạ́ ${ }^{3}$ manu boi ngga baü manu fuị-a afa. Lèlọ-a ama-ngga neu ma lasi lala, eni nea hau dè nendi manu-tèlo fuị esa baü ona au langga-ngga, ina-ngga nasu-n sia hula kapai esa lalạ, dè basa-basa hai ma ume titiạ sia na mia ma feä hela dè tao masị neu fò hela soa neu au ua kòekòe». Tembọ na aäna nggoa kaluạ na-la beöla bòe ma Mesach ina-salani-na namanène. Bòe-ma neëboị lua-n-isi, eni nae: "wah, òde nggoạ-elu-é! ngga feä mahine sa-sa esa bòe, lahine dui pepèkọ, dò mbei au hèle ala hau esa fò hemba ala-se laäbuku. Bòe-ma aänạ lua-n-isi lamatau dè ei-lima-n-elu benggèë, butạ-a mia na losa feä-n-ia dei de laändandạ́ lahine hata bè monaẹ ma bè ana-hikị, hu laänae ena; ma aäna kaluạ na ina-ama-n-elu hi fè-s leu sakola, fò hela lahine oölạ Malai ma basa-basa susula-dèkẹ ma lès lahine, basa fai lanoli iïnggat fò lahine bè hefụ ma bè idạ-a.

1 Waarschijnlijk is te lezen dala-ine-a, het dial. van D. bezigt na subst. anders steeds ine in plaats van in a.

${ }^{2}$ Netane, netá, enz. = natane, nata, enz.

s Uündandạ = Term. akandand ák. 
Mezach en Henoe (door E. J. Lopah).

Er waren twee jongens in Dengka, de één heette Mezach en zijn makker heette Henu. Op een dag zetten die beide knapen zich neder aan den kant van den weg en speelden. Toen vroeg Henoe aan Mezach: "wat hebt gij vandaag gegeten? Mezach antwoordde: «ik heb vleesch van een vogel en gekookte rijst gegeten. Gisteren heeft mijn oudere broeder Jehezkial vogelstrikken gezet en eene boschduif gevangen. O Henoe, de dij van die duif was zoo groot als die van een grooten buffel. Wij hebben haar geslacht en er platte stukken vleesch van gemaakt welke wij hebben gebakken, geroosterd, ook gekookt, gebraden en toen er van gegeten, maar er bleef nog over om te verdeelen (zoodat het) genoeg was voor (de lieden uit) alle huizen in de buurt. Ik denk, dat er in Rotti geen vogel is zoo groot als de boschduif». Toen sprak Henoe: "ik denk, dat een tam hoen niet zoo groot is als een wild hoen. Eergisteren, nadat mijn vader naar het bosch gegaan was, bracht hij, toen hij terugkeerde, een ei van een wild (hoen) mede, zoo groot als mijn hoofd; mijn moeder heeft het in een grooten pot gekookt en wij allen en de (lieden uit) de huizen daar (bij ons) in de buurt hebben er van gegeten en nog bleef er over en daar is zout opgedaan, opdat 't voor mij zou dienen om langzamerhand op te eten». Toen die beide dwaze knapen aan het praten waren, hoorde dat de doopmoeder van Mezach. En zij maakte hen beiden aan het schrikken en sprak: "hei, die domme apen, die nog niets weten, maar zij weten wel leugens te vertellen, aanstonds zal ik een stuk hout oprapen en ze slaan, dat zij opspringen». En de beide knapen werden bang en beefden over alle leden; van toen af aan pas ${ }^{1}$ tot op heden toe weten zij te onderscheiden, wat groot en wat klein is, omdat zij grooter geworden zijn; en de ouders van die beide knapen vonden goed hen naar school te laten gaan, opdat zij Maleisch zouden kunnen spreken en alle letters zouden kennen en lezen, alsook nog het rekenen zouden leeren om te weten, wat veel of weinig is.

1 Dit schijnt de beteekenis van buta-ä te zijn.

2 Vgl. bij dit in Dengka gangbare woord voor "weinig" (i dạ-a). Tett., Letti, Kissar ida, één. 


\section{NOTULEN}

VAN DE

\section{BeStuURS- EN AlgEMEENE VERGaderINGEN}

VAN HET

\section{KONINKLIJK INSTITUUT}

VOOR DE

Taal-, Land- en Volkenkunde van Nederlandsch-Indië.

$$
1912-1913 .
$$

